\title{
A REVIEW OF THE FAMILY CANIDAE, WITH A CLASSIFICATION BY NUMERICAL METHODS
}

BY

JULIET CLUTTON-BROCK, GORDON B. CORBET \& MICHAEL HILLS

Pp II7-I99; II Text-figures, 9 Tables

BULLETIN OF

THE BRITISH MUSEUM (NATURAL HISTORY) ZOOLOGY Vol. 29 No. 3

LONDON: 1976 
THE BULLETIN OF THE BRITISH MUSEUM (NATURAL HISTORY), instituted in I949, is issued in five series corresponding to the Scientific Departments of the Museum, and an Historical series.

Parts will appear at irregular intervals as theybecome ready. Volumes will contain about three or four hundred pages, and will not necessarily be completed within one calendar year.

In I965 a separate supplementary series of longer papers was instituted, numbered serially for each Department.

This paper is Vol. 29 No. 3 of the Zoology series. The abbreviated titles of periodicals cited follow those of the World List of Scientific Periodicals.

World List abbreviation

Bull. Br. Mus. nat. Hist. (Zool.).

ISSN 0007-I498

(C) Trustees of the British Museum (Natural History), 1976 


\title{
A REVIEW OF THE FAMILY CANIDAE, WITH A CLASSIFICATION BY NUMERICAL METHODS
}

\author{
By JULIET CLUTTON-BROCK, G. B. CORBET \& M. HILLS
}

\begin{tabular}{|c|c|c|c|c|c|c|c|c|c|c|}
\hline & & & $\mathrm{CO}$ & NTENT & & & & & & \\
\hline & & & & & & & & & & Page \\
\hline SyNOPSIS & . & . & . & . & . & . & . & . & . & II9 \\
\hline INTRODUCTION & . & . & . & . & . & . & . & - & • & 120 \\
\hline ChaRACTERS OF THE & CANI & DAE & . & . & . & . & . & . & . & I 2 I \\
\hline SOURCES OF DATA & . & . & . & . & . & . & . & . & . & 123 \\
\hline SELECTION OF SPEC & ECIES & . & . & . & . & . & . & . & . & 123 \\
\hline DERIVATION OF DA & ATA & . & . & . & . & . & . & . & . & 124 \\
\hline NATURE OF THE DAT & & . & . & . & . & . & . & . & . & 125 \\
\hline KINDS OF CHARACI & ETERS & & . & . & . & . & . & . & . & 125 \\
\hline USE OF THE DATA & MATR & & . & . & . & . & . & . & . & I 25 \\
\hline MEASUREMENT OF SII & IMILAI & RITY & . & . & . & . & . & . & . & 126 \\
\hline Numerical RESULTS & & . & . & . & . & . & . & . & . & $\mathbf{2} 26$ \\
\hline DISTRIBUTION OF $\mathrm{s}$ & SIMIL & ARITY & & . & . & . & . & . & . & $\mathbf{1 2 6}$ \\
\hline NeAR NEIGHbours & & . & . & . & . & . & . & . & . & I 28 \\
\hline TWO-DIMENSIONAL & L PLOT & & . & . & . & . & . & . & . & 128 \\
\hline Similarity VALUE: & ES FOR & THE I & EXIST & NG CLAS & ICATIO & & . & - & - & I33 \\
\hline HOMOGENEITY OF & THE ? & IHREE & MAIN & GENERA & . & . & . & . & . & 136 \\
\hline Automatic Classi & SIFICA & rION & . & . & . & . & . & . & - & I37 \\
\hline GENERAL TAXONOMIO & IC CON & CLUSIO & ons & . & . & . & . & . & . & I39 \\
\hline Systematic ACCOUNI & & . & . & . & . & . & . & . & . & I4I \\
\hline Genus Canis & . & . & . & . & . & . & . & . & ${ }^{\circ}$ & I4I \\
\hline Genus Vulpes & . & . & . & . & . & . & . & . & - & 150 \\
\hline Genus Alopex & . & . & . & . & . & . & . & . & . & I6I \\
\hline Genus Otocyon & . & . & . & . & . & . & . & . & . & I62 \\
\hline Genus Nyctereutes & & . & . & . & . & . & . & . & . & I64 \\
\hline Genus Dusicyon & . & . & . & . & . & . & . & . & . & I65 \\
\hline Genus Chrysocyon & & . & . & . & . & . & . & . & . & 176 \\
\hline Genus Speothos & . & . & . & . & . & . & . & . & . & I 77 \\
\hline Genus Cuon & . & . & . & . & . & . & . & . & . & I 79 \\
\hline GenUs Lycaon & . & . & . & . & . & . & . & . & . & 180 \\
\hline ACKNOWLEDGEMENTS & & . & . & . & . & . & . & . & . & I 81 \\
\hline Appendix I: Data m & MATRI & CES & . & . & . & . & . & . & . & 182 \\
\hline APPENDIX II: LicE ( & (Рнth & HIRAPT & ERA) & OF THE & NIDAE & . & . & . & - & I94 \\
\hline REFERENCES . & . & . & . & . & . & . & . & . & . & 195 \\
\hline
\end{tabular}

\section{SYNOPSIS}

Within the accepted classification of the Canidae it is usual to recognize three subfamilies, fourteen genera and thirty-seven species, excluding the domestic dog. Using numerical methods and a total of ninety characters an analysis has been carried out of the overall similarity between thirty-five of these species plus two breeds of domestic dog. The specimens used for this analysis are in the collections of the British Museum (Natural History). Classification above 
the level of species has been critically examined on phenetic characters. The results demonstrate the isolated positions of the monospecific genera Lycaon, Speothos and Cuon and do not strongly support their grouping as a discrete subfamily. The status of Otocyon, Nyctereutes, Chrysocyon and Alopex as monospecific genera is also upheld although Alopex is clearly related to the other foxes of the genus Vulpes. Urocyon and Fennecus are included in Vulpes, and Cerdocyon and Atelocynus in Dusicyon.

The three larger genera, Canis, Vulpes and Dusicyon, are retained although they are closely interrelated. Vulpes vulpes is shown to be a distinctly atypical member of its genus. The position of the extinct Falkland Island wolf was found to be enigmatic but it is provisionally retained with other species of Dusicyon.

A systematic description is given of each species and the data are presented as a series of tables that may be used for reference.

\section{INTRODUCTION}

THE Canidae, comprising the dogs and foxes, is one of the most clear-cut families of mammals and its content has rarely been seriously disputed since Gray (I82I, I825) first used the name in its present form. Exceptions to this unanimity amongst taxonomists have been the proposal to include the bears and the dogs in a single family (Winge, I924); and at the other extreme the splitting of the Canidae by giving family rank to some of its more aberrant members, e.g. the Otocyonidae of Trouessart (I885) for the single species Otocyon megalotis, the bat-eared fox. Neither of these courses has received general acceptance.

The relation of the Canidae to other families of carnivores has been rather more controversial. This was discussed in some detail by Simpson (I945) who accepted the grouping of the Canidae with the Ursidae (bears), Procyonidae (racoons etc.) and Mustelidae (weasels etc.) in a superfamily Canoidea (frequently called the Arctoidea in the older literature), contrasting with the superfamily Feloidea (frequently Ailuroidea in the past) containing the Felidae (cats), Viverridae (civets etc.) and Hyaenidae (hyaenas).

In contrast to the stable concept of the family Canidae, classification within the family has been distinctly unstable. At the species level revisionary work has progressively clarified the limits of the separate species until at present the only real uncertainty concerns the South American forms usually placed in the genus Dusicyon s.l. Classification at the generic level has been particularly unstable and even those generic allocations that have stood intact for the past century have done so by neglect rather than by the soundness of their foundations. The genus Cuon for example, containing the single species $C$. alpinus, the red dog of S.E. Asia, is usually diagnosed in terms of a single character, namely the absence of third lower molars. The Simien jackal of Ethiopia has been variously considered to be the sole member of a genus Simenia or has been placed with the other jackals in Canis. Likewise the Arctic fox has been given generic rank as Alopex lagopus or has been included in Vulpes. Although these are to some extent questions of taxonomic rank there has been a tendency to attempt to settle them in isolation without taking into account other members of the genera concerned. 
Grouping of the genera into subfamilies has been equally controversial. Simpson (I945) probably followed some degree of consensus in recognizing three subfamilies : Otocyoninae (Otocyon), Simocyoninae (Lycaon, Cuon, Speothos) and Caninae (all other genera). But these members of the Simocyoninae are so diverse that many doubts have been expressed about the validity of such a grouping.

The last comprehensive revision of the Canidae was that of Mivart (I890) since when an enormous amount of relevant data has accumulated and many piecemeal taxonomic changes have been made. The main objective of the present study was therefore to revise the classification within the family, taking account of all species and all available characters. No attempt was made to resolve outstanding problems at the species level.

The principle followed in determining which characters to use was to include all characters that showed clear-cut interspecific differences anywhere within the family. Most previous studies of classification in mammals using numerical methods have been confined to limited sets of characters, e.g. that of parts of the Felidae by Imaizumi ( 1967 ) using only the skull and that of New Guinea rodents by Lidicker (I973) using only the penis. These seem to have the weakness of including many characters that show very little variation within the group concerned and of ignoring major differences in other parts of the body. By using all those characters showing major, clear-cut differences between species, it was hoped that a sufficiently large and representative sample of characters would be obtained without having to include the more subtle differences that can only be detected in terms of differences in mean value between one species and another.

As is the case with most groups of mammals, literature on the Canidae is excessively fragmented. It was therefore considered that the data matrices would in themselves be a useful source of information and they are presented here (Tables 4-9) in a form that we hope will be of value for reference. Recently a comprehensive popular account of the family has been produced by Bueler (I974), and a more technical review, within the framework of behaviour patterns, by Fox (I975).

\section{CHARACTERS OF THE CANIDAE}

The Canidae are cursorial, terrestrial carnivores that have their young in burrows or dens in the ground. The family is distributed over the greater part of the habitable world with the exception of some oceanic islands. The species may be solitary, hunting on their own or in restricted family groups and living off small prey, or they may be social pack animals like the wolves that hunt large prey. All canids will feed on some vegetable matter and carrion, especially when the preferred diet is scarce. In all species the jaws are well developed, the head is longer than in the cat family, and the ears are prominent. The body is lightly built and the limbs are long. Pelage characters are variable but the dominant colours are black, white, grey and ochreous or tawny brown. There is usually a dense underfur mixed with longer dark or 'agouti' guard hairs (Little, I957). The tail is usually bushy, often with a contrasting black or white tip and a patch of dark hairs on the dorsal part covering a glandular area (called the 'tail gland' throughout this work, see 
Hildebrand, I952b). The fur is thicker and lighter coloured in the winter and in low temperature zones. The underparts of the body, inner sides of the limbs and insides of the ears are usually paler in colour than the rest of the body.

The sense organs are well developed and most species are predominantly nocturnal. Individuals communicate with each other by facial expression, body and tail posture and by howling, yelping or barking.

The limbs are long and slender and adapted for swift running. There are four functional digits on each limb. On the fore-limb in all species except Lycaon pictus the first digit is vestigial and is represented by a claw and small pad higher up on the foot than the four functional pads. In L. pictus this digit is totally absent. In the domestic dog and dingo a vestigial first digit may also be present as a 'dew claw' on the hind limb as well. This may be occasionally observed in wild canids (see, for example, Lönnberg, I9I6, for a report of 'dew claws' on a wild fox).

The facial part of the skull in the Canidae is elongated, the zygomatic arches are wide and the bony orbits never form a complete ring. The temporal ridges may be either wide and enclose a lyriform sagittal area or they may be fused to form an interparietal crest. The 'brows', that is, the part of the frontal bones above and between the eyes, may be slightly dished, as in the foxes, flat as in most of the species of Dusicyon or convex as in the dog and wolf. The development of the 'brows' is a reflection of the size of the frontal sinuses. The postorbital process of the frontal bone usually ends in a small point. The auditory bulla is relatively large, rounded and divided internally by an incomplete septum.

The dental formula for all species is, $\mathrm{I} \frac{3}{3}, \mathrm{C} \frac{\mathrm{I}}{\mathrm{I}}, \mathrm{P} \frac{4}{4}, \mathrm{M} \frac{2}{3}$, with the following exceptions: Otocyon megalotis $-\mathrm{I} \frac{3}{3}, \mathrm{C} \frac{\mathrm{I}}{\mathrm{I}}, \mathrm{P} \frac{4}{4}, \mathrm{M} \frac{3}{4} ;$ Speothos venaticus $-\mathrm{I} \frac{3}{3}, \mathrm{C} \frac{\mathrm{I}}{\mathrm{I}}, \mathrm{P} \frac{4}{4}, \mathrm{M} \frac{\mathrm{I}}{2}$; Cuon alpinus $-\mathrm{I} \frac{3}{3}, \mathrm{C} \frac{\mathrm{I}}{\mathrm{I}}, \mathrm{P} \frac{4}{4}, \mathrm{M} \frac{2}{2}$. In every species except $O$. megalotis $\mathrm{P}^{4}$ and $\mathrm{M}_{1}$ (the carnassials) are larger than all the other teeth; they are trenchant and bite together with a shearing action. In Otocyon, however, these teeth are molariform and no larger than the rest. In all canids the canine teeth are long and more or less sharply pointed; the premolars are also pointed and have one main cusp. The molars, with the exception of the lower carnassial $\left(\mathrm{M}_{1}\right)$, are bunodont. In the majority of species the talonid or heel of the lower carnassial has two cusps, but in $S$. venaticus, $C$. alpinus and $L$. pictus it is crested and has only one cusp. The homologies and development of the cusp patterns in the Canidae were discussed by Marett Tims (I896) but it is a subject that has since received little attention.

In general, the canids being highly cursorial, the family is not found in dense forest areas; three exceptions are C. alpinus (Oriental region), S. venaticus and Dusicyon microtis (both of the Brazilian subregion of South America). All the races of wolf and almost all the species of true fox (genus Vulpes) are found in the northern hemisphere. The coyote, Canis latrans, of North America is replaced in southern Europe, Africa and the Orient by the several species of jackal. In Africa the ecological niche of the wolf is taken by $L$. pictus, the hunting dog. 


\section{Selection of species}

The 37 species of wild canids are listed below, named and arranged according to what can be considered a consensus of current views on their classification. The arrangement of subfamilies and genera follows Simpson (I945) except that Cerdocyon and Atelocynus are given generic rank following Cabrera (I958). The species are delimited according to the most recent major regional works, namely those of Ellerman \& Morrison-Scott (I966) for the Palaearctic and Oriental regions, Ellerman et al. (I953) for southern Africa, Hall \& Kelson (I959) for North America and Cabrera (I958) for South America. Canis simensis, from Ethiopia, is the only species not included in these and its specific distinctness has never been in doubt. All of these species were used in this study with two exceptions, marked *, of which no specimens were available in the British Museum (Natural History). These are Urocyon littoralis, the grey fox from the Santa Barbara Islands, California, treated as specifically distinct from the continental Urocyon cinereoargenteus by Hall \& Kelson, and Canis rufus $(=C$. niger $)$, the red wolf of southeastern U.S.A. Both of these appear to be sufficiently similar to their better known relatives, $U$. cinereoargenteus and Canis lupus respectively, that their generic allocations can be presumed to follow those of the larger species.

The generic name Oreocyon, replaced by Dasycyon (sic), has been proposed for a new species of canid, Dasycyon hagenbecki, based on a single skin from the Andes of South America (see Krumbiegel, I953). The existence of this species has not been corroborated by further finds and we have not included it in this study. In addition to these wild species two forms of domestic dog were included, the dingo of Australia to represent a primitive breed and the bloodhound as an example of a highly differentiated breed.

Present classification of the family Canidae :

Subfamily CANINAE

Canis lupus Wolf

Canis rufus Red wolf*

Canis latrans Coyote

Canis aureus Golden jackal

Canis mesomelas Black-backed jackal

Canis adustus Side-striped jackal

Canis simensis Ethiopian jackal

Alopex lagopus Arctic fox

Vulpes vulpes Common or red fox

Vulpes corsac Corsac fox

Vulpes ferrilata Tibetan sand fox

Vulpes bengalensis Bengal fox

Vulpes cana Blanford's fox

Vulpes rueppelli Sand fox

Vulpes pallida Pale fox

Vulpes chama Cape fox

Vulpes velox Kit fox
Europe, Asia, N. America, Arctic

Central N. America

N. America

S.E. Europe, N. Africa, S. Asia

Africa south of the Sahara

Africa south of the Sahara

Mountains of Ethiopia

Arctic

Europe, N. Africa, Asia, N. America

Central Asia

Tibetan plateau

India

S.W. Asia

N. Africa, S.W. Asia

Southern edge of Sahara

S. Africa

N. America 
Fennecus zerda Fennec fox

Urocyon cinereoargenteus Grey fox Urocyon littoralis* Island grey fox

Nyctereutes procyonoides Raccoon dog

Dusicyon australis Falkland Island wolf

Dusicyon culpaeus Colpeo fox

Dusicyon culpaeolus

Dusicyon gymnocercus Azara's fox

Dusicyon inca

Dusicyon griseus Argentine grey fox

Dusicyon fulvipes Chiloe fox

Dusicyon sechurae Sechura desert fox

Dusicyon vetulus Hoary fox

Cerdocyon thous Common zorro

Atelocynus microtis Small-eared zorro

Chrysocyon brachyurus Maned wolf

Subfamily SIMOCYONINAE

Speothos venaticus Bush dog

Cuon alpinus Dhole

Lycaon pictus Hunting dog

Subfamily OTOCYONINAE

Otocyon megalotis Bat-eared fox
N. Africa, Arabia

N. America, northern S. America

Islands off California

E. Asia

Falkland Is., extinct since $c$. I 880

S. America - Patagonian subregion

Uruguay

Eastern Patagonian subregion

Mountains of Peru

S.W. Patagonian subregion

Island of Chiloe

N.W. Peru, Ecuador

Brazil

S. America - Brazilian subregion

Central S. America - Brazil

Southern Brazilian subregion

S. America - Brazilian subregion

E. and Central Asia

Africa south of the Sahara

Africa south of the Sahara

\section{Derivation of data}

The data relating to each species were derived primarily from specimens in the collections of the British Museum (Natural History), supplemented by information from the literature. Whenever possible, three skulls and skeletons of each species were selected and included one male and one female. All measurements were taken with dial calipers. The skeletal measurements are defined in the figures accompanying Tables 4,5 , and 8 . A character that has been used in diagnosing the genera of canids is the relative development of the frontal sinuses in the skull. In order that this character could be assessed correctly at least one skull from each genus was sectioned diagonally through the cranium to expose the sinuses.

For characters of the pelage all the skins of most of the species were examined and scoring was done on between 3 and ro skins. In defining the pelage characters account was taken of the genetics of coat colour as described by Little (I957). Assessments of hair and skin colours were made by eye and estimates of the thickness of the hair were made by rubbing one hair at a time between the thumb and forefinger.

Characters concerning internal anatomy, body proportions of the live animal, and comparative behaviour were extracted from published works and were scored in the 
same way as the directly measured variables. The sources of these data are given with the descriptions of the characters in Tables 4-9.

\section{NATURE OF THE DATA}

\section{Kinds of characters}

The list of characters given in Tables 4-9 (p. I82) includes qualitative, quantitative and derived characters.

Qualitative. These are characters whose values are simply alternatives from a list. Comparisons of magnitude between the different values are meaningless.

Quantitative. There are two main types of quantitative character. The first takes values on an ordinal scale for which comparisons of order are possible. For example character 7 , Table 7 , dark patch on dorsal surface of tail, takes the values absent/short/ long and short is intermediate between absent and long. The second takes values on a scale for which differences and ratios of values may be compared. All the linear measurements on the skull fall into this category.

Derived. These are characters whose values are derived from the actual observations on the specimen. The condylo-basal length of the skull was used as the best available measure of overall size. Since the range of size in the family is very considerable, all other linear measurements were used in the form of ratios, frequently to condylobasal length. The attempt to eliminate size-dependence by using characters derived as ratios can only be partially successful, but at least the derived characters are measuring aspects of shape which are far less size-related than the original characters.

All the character values were obtained separately for each specimen. For quantitative characters these values usually varied within a species and a value for the species was obtained by averaging the values for the specimens. For characters taking values on an ordinal scale the coded values (such as I, 2, 3) were averaged. This is not ideal because it presumes that 2 is exactly halfway between $I$ and 3 whereas it is only known that 2 is intermediate between I and 3 . Because the values of these characters did not vary much in this study the difficulty was ignored. The values of qualitative characters showed no variation so the common value was used for the species.

\section{Use of the data matrix}

The characters employed have been presented in Tables 4-9 in a form suitable for general-purpose reference. There are, however, limitations on their use that must be stressed. In particular the mean values given for the quantitative characters should not be used for further statistical studies without taking full account of the very small sample size (usually three). In the context of the analysis presented here, using 90 characters, it is thought that the errors inherent in these mean values are not important, especially where the range of values for a given character is 
great, e.g. condylo-basal length of the skull for which the mean value for a species varies from 82 to $226 \mathrm{~mm}$. It would, however, be quite inappropriate to use these figures as a precise measure of the difference in value between closely similar species, especially in the case of those species such as Canis lupus and Vulpes vulpes that have enormous ranges and considerable geographical variation. For the same reason elaborate and more accurate methods of measuring characters of the pelage were considered to be inappropriate.

The main value of the data matrix is, we believe, in showing how the characters of a particular species relate to the variation found in the family as a whole, rather than as a basis for the detailed comparison of closely related species.

\section{MEASUREMENT OF SIMILARITY}

A measure of similarity between each pair of species was obtained by first allowing both qualitative and quantitative characters to contribute amounts between $\mathrm{o}$ and roo, and then averaging the contributions over characters. The rules were :

(i) a qualitative character contributed roo if the two species had the same value and o otherwise, regardless of whether the value represented the 'presence' or the 'absence' of something ;

(ii) a quantitative character contributed an amount proportional to the difference in the character value for the two species; the proportion was chosen so that the largest difference between any pair of species in the study contributed roo and a zero difference contributed 0 ;

(iii) if a character was recorded as missing on a species because its value was not known then that character was ignored when assessing similarity of all other species with that species.

This way of measuring similarity is the method used in the CLASP package of programs for numerical taxonomy (Rothamstead Experimental Station) and has been discussed in detail by Gower (I97I). A number of minor variations in the method are included in the package.

All analyses of similarity values were carried out twice : once using all the characters listed in Tables 4-9 (referred to as 'All characters') and again using only characters of the skull and teeth (Tables 4 and 5), these being the characters that traditionally have been given greatest weight in mammalian classification.

\section{NUMERICAL RESULTS}

\section{Distribution of similarity}

The result of the process of selecting characters, observing their values and measuring similarity is a set of similarities on a scale $0-100$ consisting of one for each pair of species. In this study there were 37 species and 666 similarities. Frequency distributions of similarities are shown in Fig. I and indicate the range of 

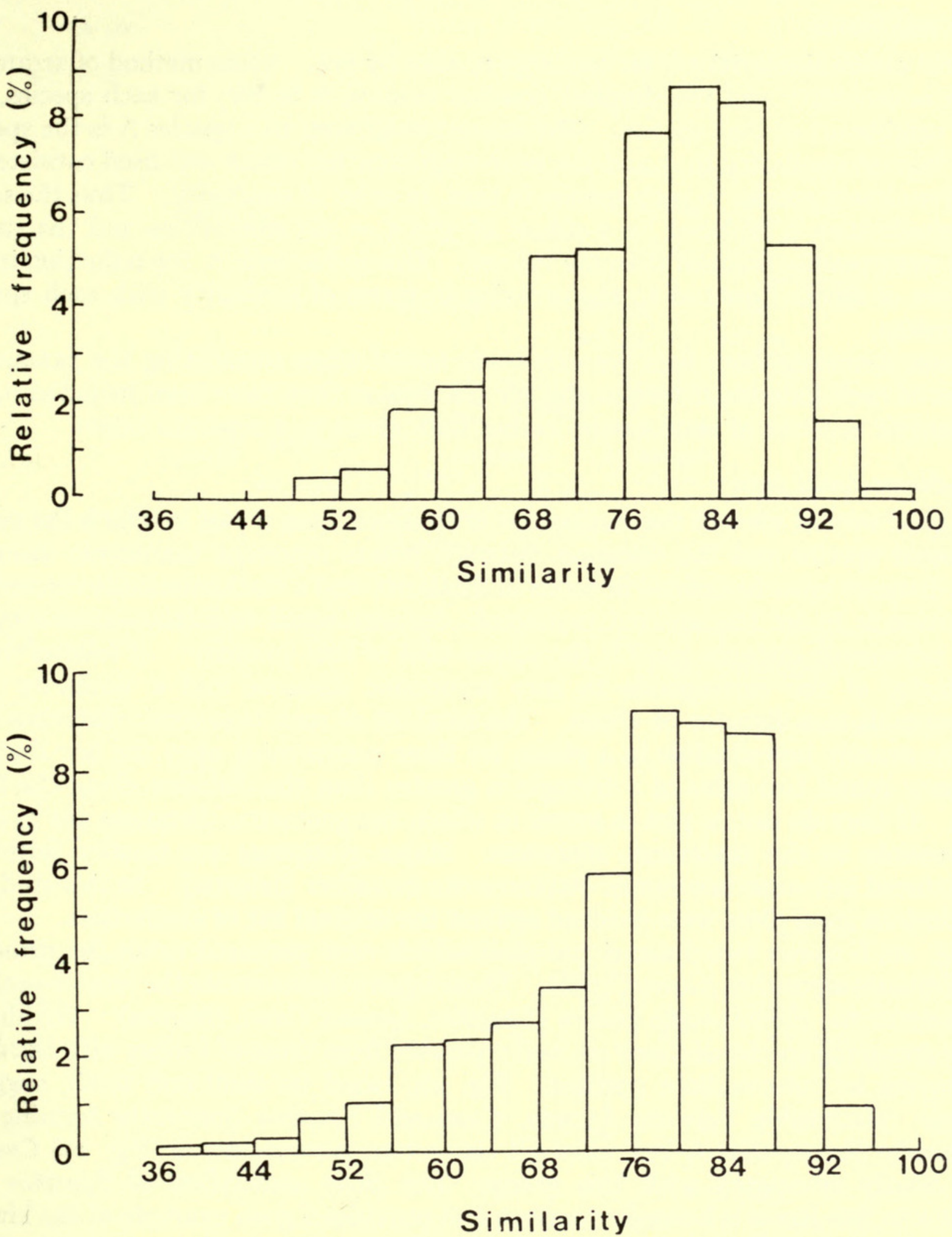

FIG. I. Relative frequency distribution of the similarity values: a. (above) all characters; b. (below) skull and teeth only.

values observed. Such distributions are useful for assessing which values of similarity correspond to 'high' and 'low'. The distribution based on the cranial and dental characters is similar to that based on the full list but has a longer left tail with some similarity values as low as 36 . 


\section{Near neighbours}

A set of 666 similarities is far too large to scan by eye. Some method of arranging them is necessary and the simplest possible method is to list, for each species, the near neighbours of that species. The nearest neighbour to a species $\mathrm{A}$ is the species with highest similarity to A and the near-neighbour list which was used consisted of the five closest species to each species in turn, in order of similarity. Thus the set of 666 similarities is replaced by a subset of $37 \times 5=185$ similarities and the subset is far more readily scanned than the full set. This is due both to the reduction in the number of similarities and to the ordering in terms of similarity with each species separately.

These near-neighbour lists are extremely useful when considering the taxonomic status of each individual species and for this reason they have been included in the systematic account of each species rather than given as a separate table.

\section{Two-dimensional plots}

A good overall view of the similarities is obtained from a plot in which the points represent species and the distances between points represent taxonomic distance. This distance must be defined in terms of similarity and a mathematically convenient definition is to set the squared taxonomic distance equal to 2 (100-similarity) so that taxonomic distance itself is the square root of this quantity. It follows that a similarity of Ioo corresponds to zero taxonomic distance and a similarity of 0 corresponds to a distance of $\sqrt{ } 200$. The total set of such taxonomic distances may not be exactly reproducible in a plane, for three points must obey the law that the distance round two sides of a triangle is greater than the distance along the third side. If they do not, a plot is found in which the geometric distances are as close as possible to the taxonomic distances. Major groupings are usually faithfully reproduced but some taxonomic distances can be rather distorted. In this study all conclusions from plots were checked against the original list of similarities.

Fig. 2a, b shows two-dimensional plots which were prepared using the principal co-ordinates algorithm (Gower, I966). These figures demonstrate the remote position of some of the monospecific genera (Speothos, Lycaon, Cuon, Otocyon). Within the main group the species of Canis are well separated from those of Vulpes with Dusicyon occupying an intermediate position. Fig. 2b, based on skull and teeth, suggests a close relationship between Lycaon, Cuon and Speothos (currently forming the subfamily Simocyoninae) but when all characters are considered (Fig. 2a) Cuon is less closely associated with this group. The close association of Speothos and Lycaon in this figure is however spurious and provides a good example of the kind of distortion that can arise in this kind of plot. The taxonomic distance between them is $\sqrt{ }(2 \times 32)=8.0$ whereas the distance on the plot is only 0.8 . On the other hand, the taxonomic distance between Speothos and Vulpes bengalensis is $\sqrt{ }(2 \times 4 \mathrm{I})=9^{\circ} 0$ and the distance on the plot is 7.5. The relationship between Speothos (and Lycaon) and the Caninae is generally well represented but not the relationship between Speothos and Lycaon. The distortion could be slightly reduced by adding a third dimension, but the improvement is bought at the cost of a far more cumbersome diagram (the so-called 'plumber's diagram'). 

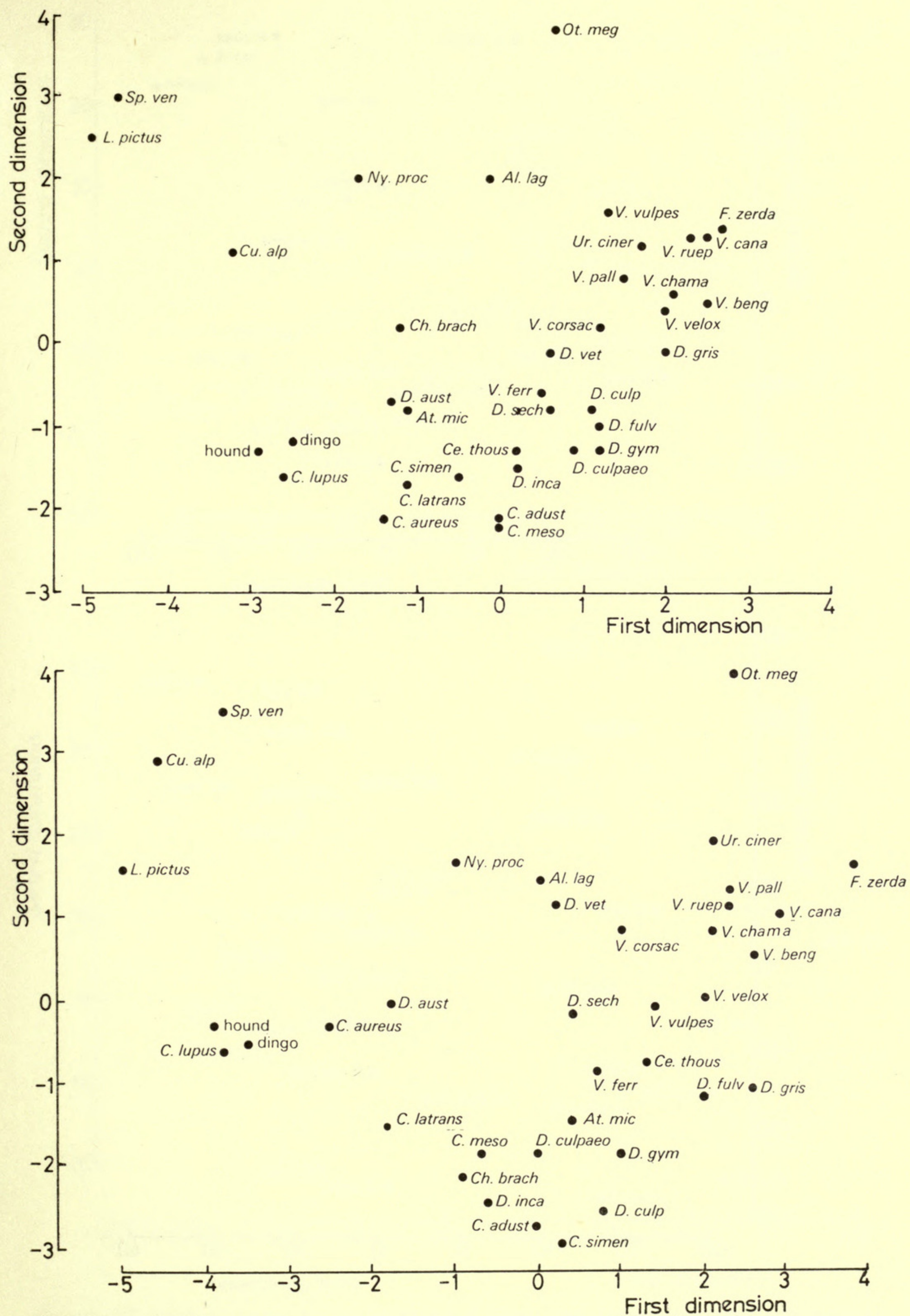

FIG. 2. Two-dimensional plot of all 37 species using the principal co-ordinates algorithm : a. (above) all characters; b. (below) skull and teeth only. 


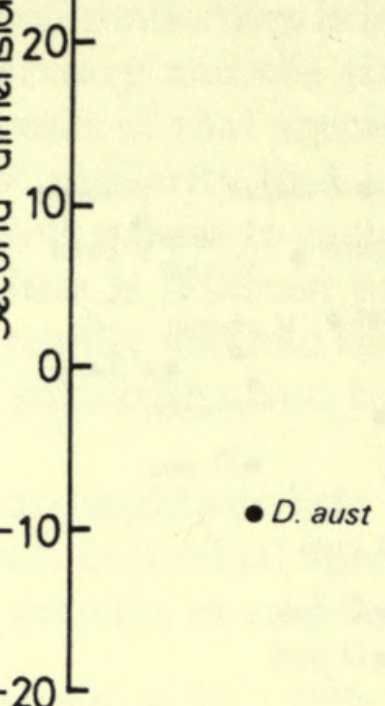

- V. chama

- V. velox

- $v$. beng
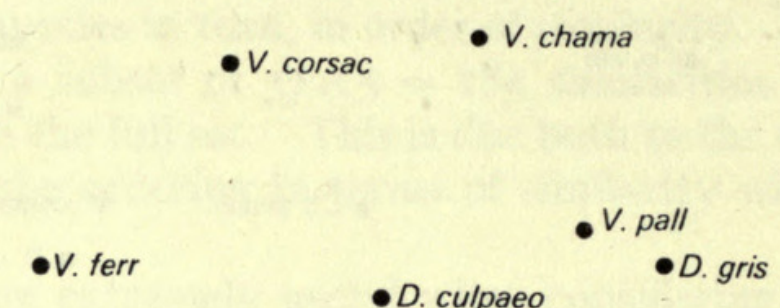

D.vet•

D. sech $\bullet \quad$ D. gym $\quad \bullet D$. fulv

$\bullet D$. inca

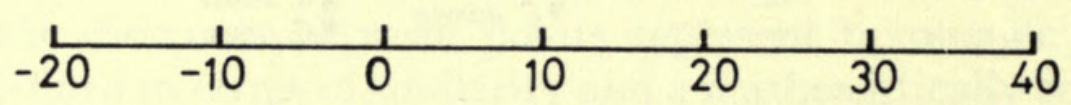

First dimension

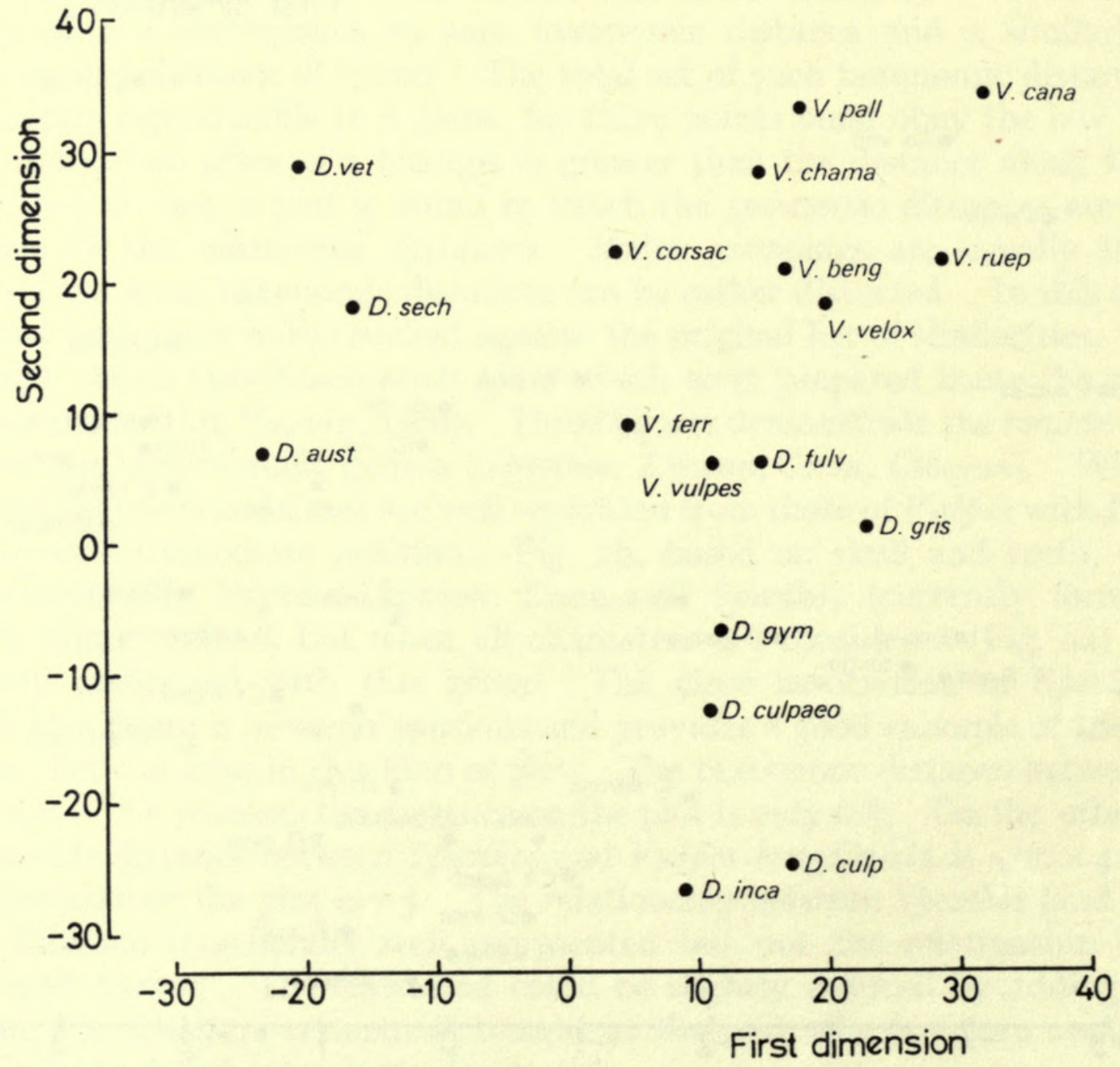

FIg. 3. Two-dimensional plot of members of Vulpes and Dusicyon using the principal co-ordinates algorithm : a. (above) all characters; b. (below) skull and teeth only. 


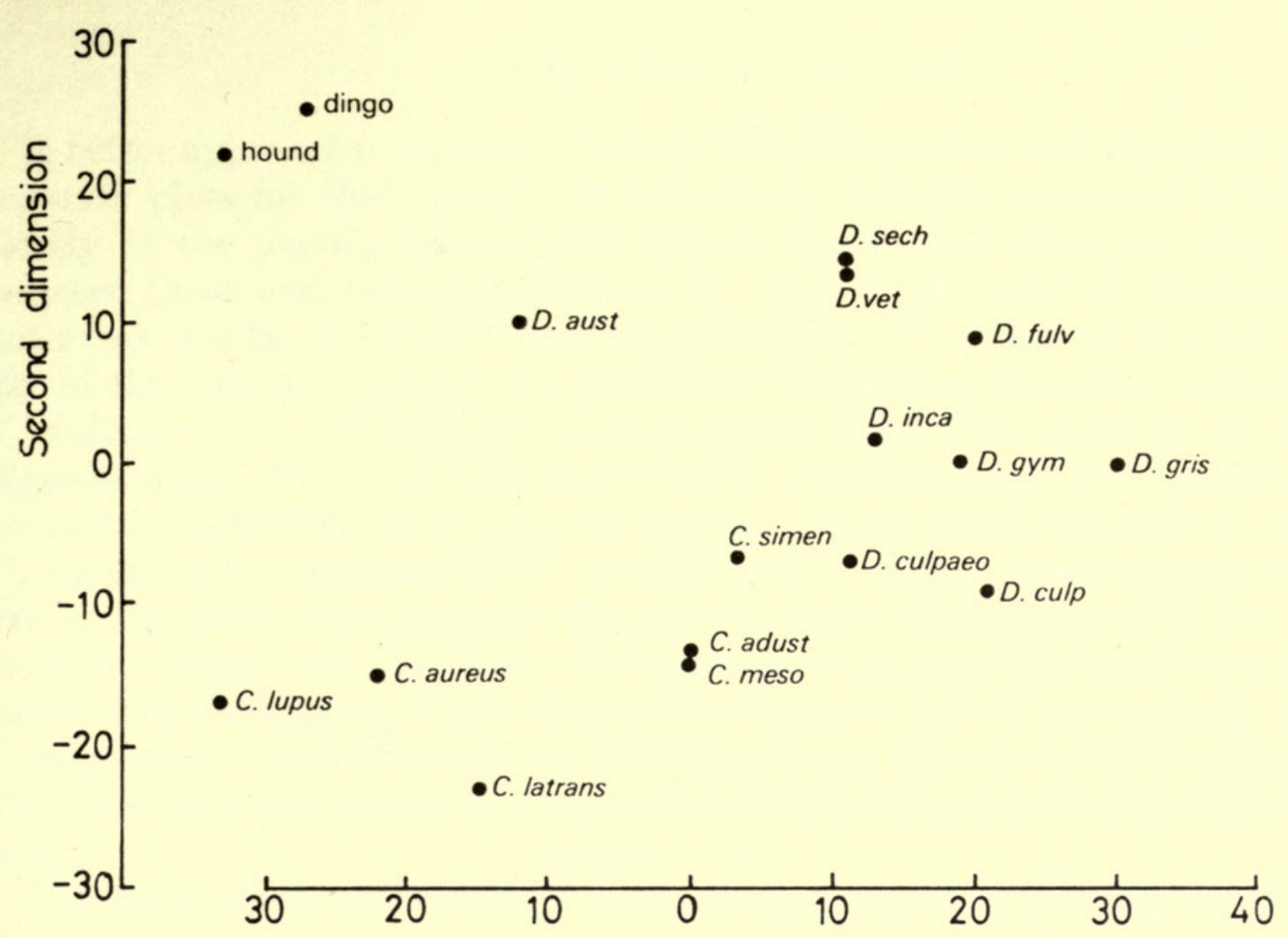

First dimension

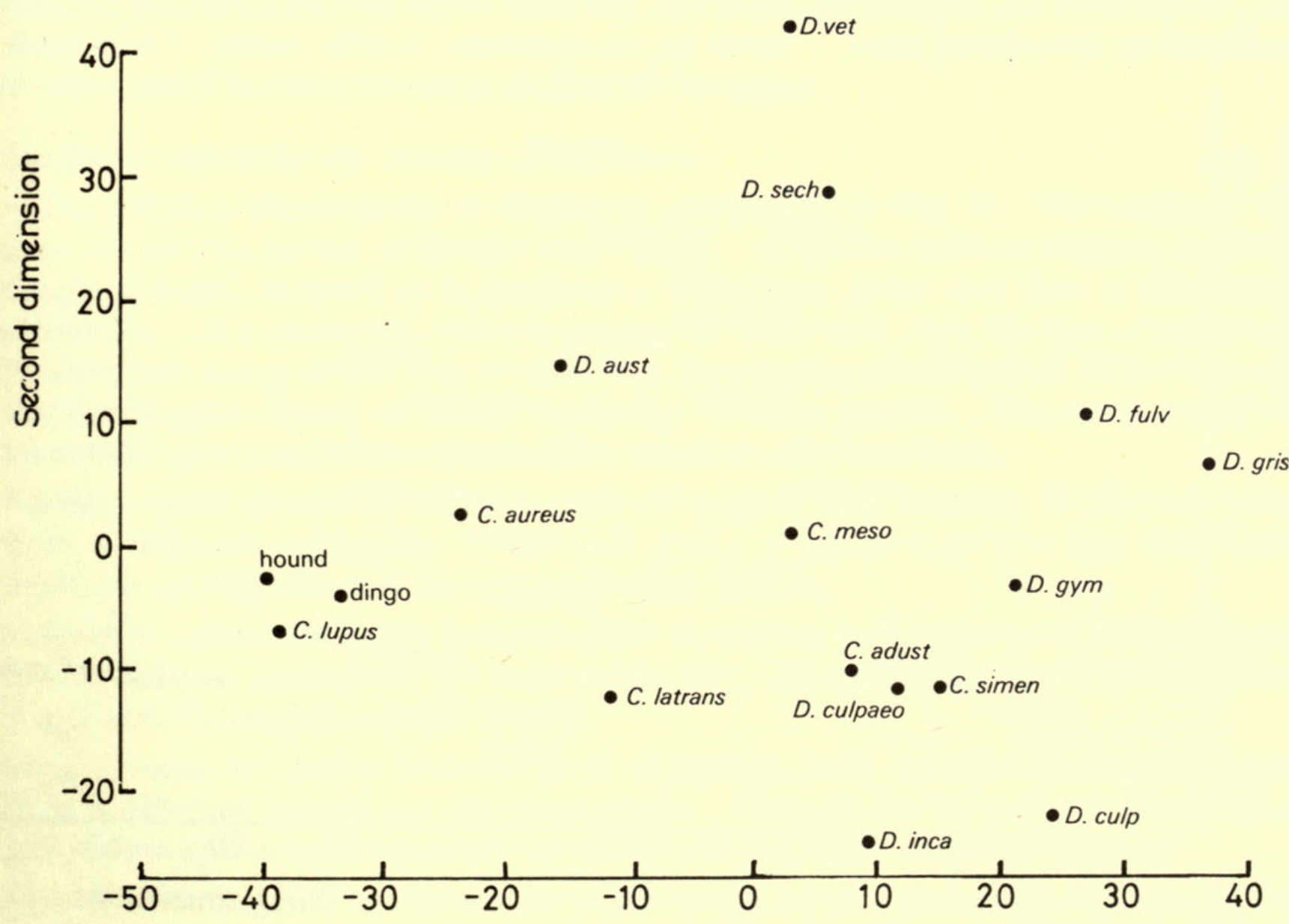

First dimension

FIg. 4. Two-dimensional plot of members of Canis and Dusicyon using the principal co-ordinates algorithm: a. (above) all characters; b. (below) skull and teeth only. 

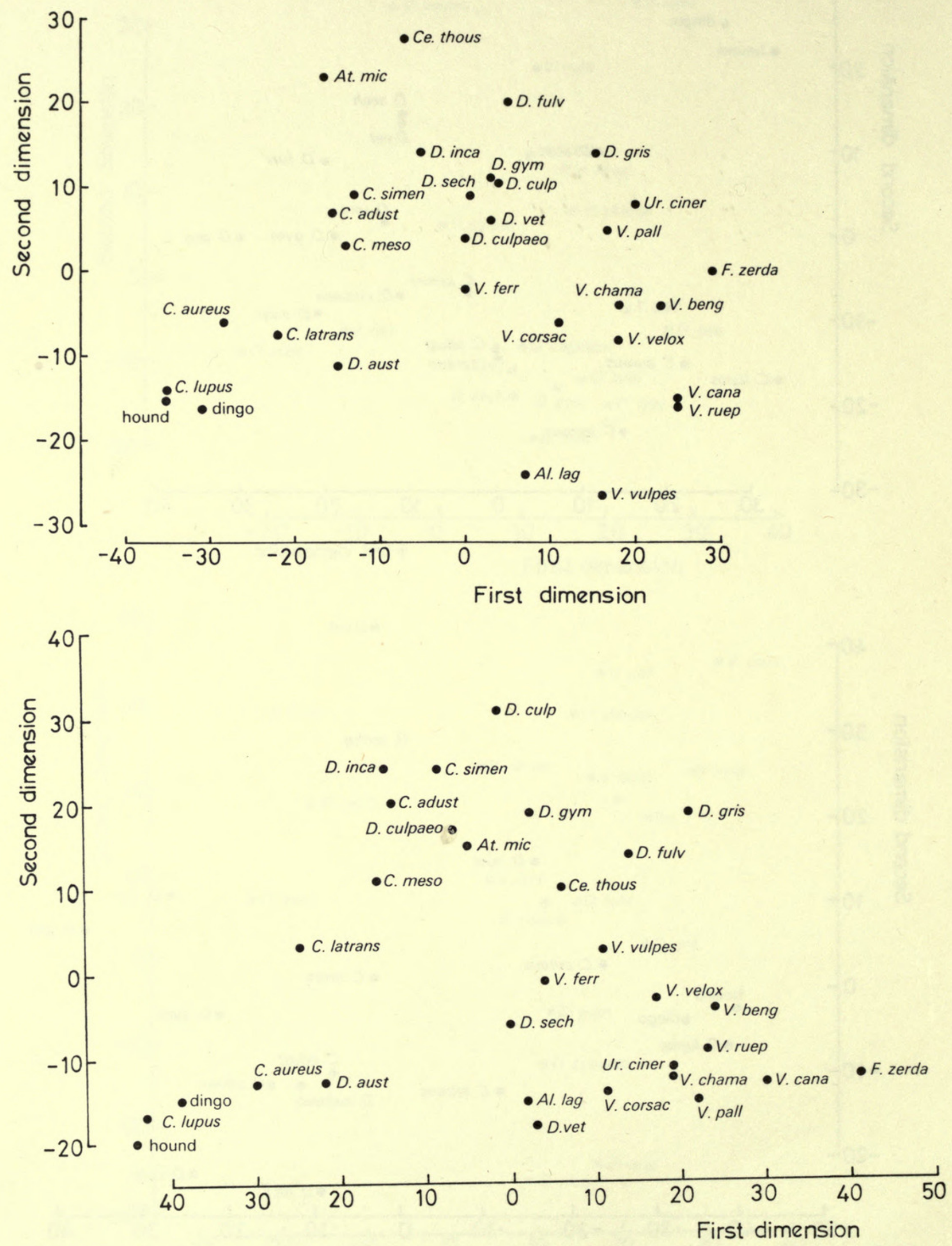

FIG. 5. Two-dimensional plot of members of the subfamily Caninae using the principal co-ordinates algorithm : a. (above) all characters; b. (below) skull and teeth only. 
A better approach is to concentrate on different parts of the main plot and prepare separate plots for these parts. In this study we were interested in looking more closely at the overlap between the genera Vulpes and Dusicyon (Fig. 3a, b) and between Canis and Dusicyon (Fig. 4a, b). In Fig. 3a, using all characters, there is not much overlap between Vulpes and Dusicyon; V. pallida is the most Dusicyonlike of the Vulpes (confirmed by its nearest neighbours according to similarity) and $V$. vulpes and $V$. ferrilata are rather atypical foxes; the position of $D$. australis suggests a low similarity with both Vulpes and Dusicyon. For cranial and dental characters only (Fig. 3b) the picture does not change much although D. sechurae and $D$. vetulus move up closer to $D$. australis and $V$. vulpes appears more fox-like. In Fig. 4 the distinction between the genera Canis and Dusicyon is less clear than between Vulpes and Dusicyon; the position of D. australis suggests a higher similarity with members of Canis than with Dusicyon, and $C$. simensis, $C$. adustus and C. mesolomas are all closer to the Dusicyon group than to other members of Canis. The same situation occurs in a more acute form using cranial and dental characters only.

The other aspect of Fig. 2 that is worth studying more carefully is the position of the less distinctive monotypic genera in relation to the large genera. These are shown in Fig. 5a, b. Using all characters there is a strong case for including Urocyon and Fennecus in Vulpes, and Atelocynus and Cerdocyon in Dusicyon. An additional point of interest from this figure (and Fig. 4b) is the grouping of the bloodhound, the dingo and $C$. lupus, with $D$. australis not far away. These points will be discussed in more detail in the systematic section of the paper.

\section{Similarity values for the existing classification}

The existing classification is displayed graphically in Fig. 6. The ranks of the taxa are species, genus, subfamily and family. A species such as Otocyon megalotis simply changes its rank as it becomes a monotypic genus and then a monotypic subfamily. If a numerical value is associated with each rank the figure becomes a dendrogram and a useful way of studying the existing classification is to construct the dendrogram based on mean similarity between species. The ranks are given numerical values as follows (similarities based on all characters).

Family - mean similarity between pairs of species, each member of the pair being from a different subfamily. There are $33 \times 3+33 \times I+3 \times I=I 35$ such combinations and the mean of the I35 similarities is $65^{\circ} \mathrm{O}$.

Subfamily - mean similarity between pairs of species, each member of the pair being from a different genus, but the same subfamily. The number of such combinations is $43 \mathrm{I}$ and the mean similarity is $79^{\circ} 8$.

Genus - mean similarity between pairs of species, each member of the pair being from a different species but the same genus. The number of such combinations is Ioo (monotypic genera contribute no pairs) and the mean similarity is $87 \cdot 3$.

Species - this is given the value roo which would be consistent with the way values have been given to genus if the specimens within a species were identical. In fact they were not, so the correct level for species should be rather less than Ioo. 


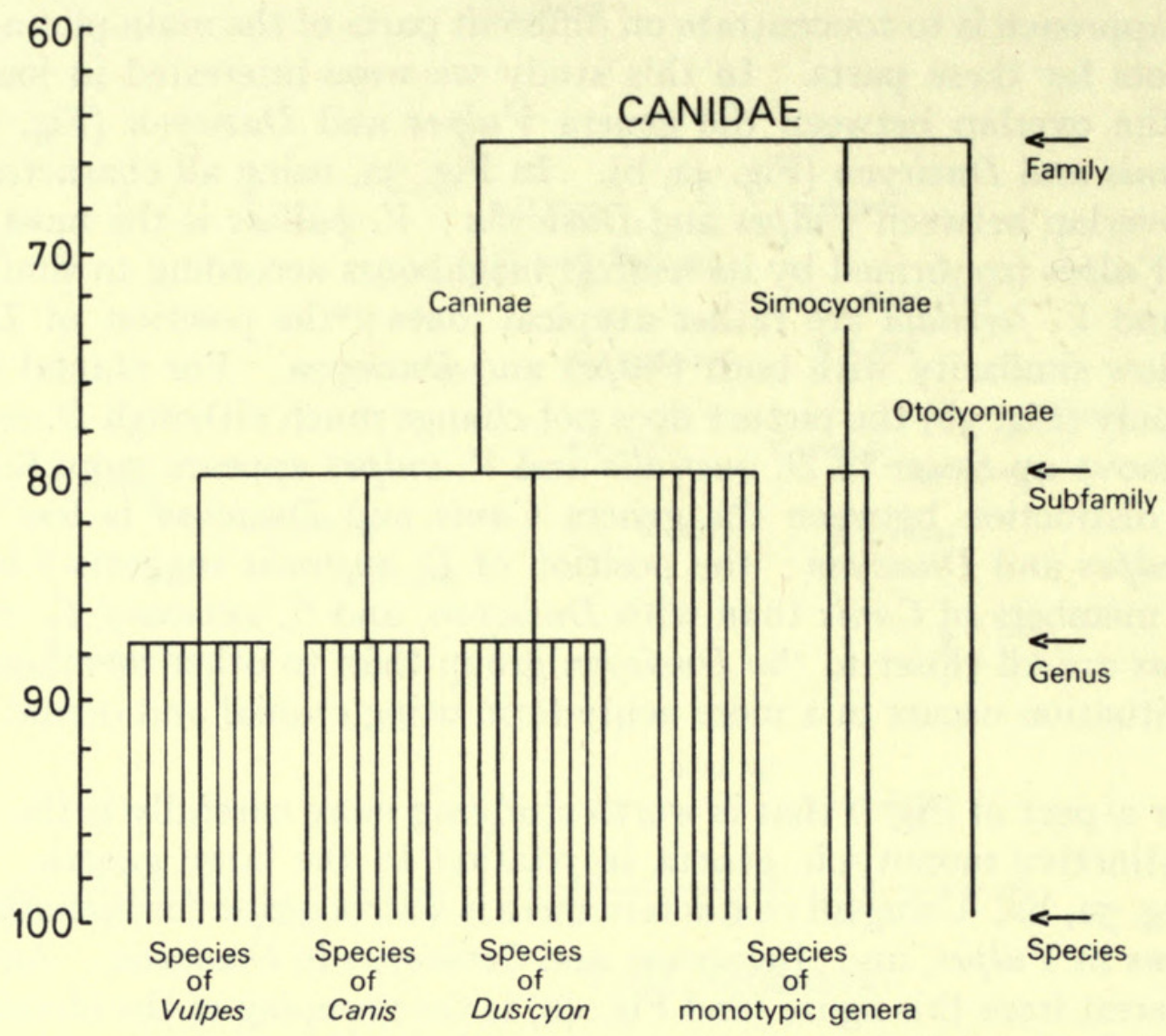

FIG. 6. Dendrogram of the existing classification : rank level equal to mean similarity between species.

To see how well this dendrogram fits the data it is necessary to examine the distribution of similarity values that go to make up each of the means described above. These are shown in Fig. 7 in the form of cumulative frequency rather than frequency distribution because the former are easier to compare. Ideally there should be little or no overlap between the ranges of values at different ranks; such a situation would indicate a very strong hierarchic structure in the similarities. In this case the overlap is rather large, particularly between subfamily and genus, which is to say that there are too many high similarities between species from different genera within the same subfamily. It is clear from Figs 3 and 4 that there is not much one can do about this. Even if D. australis were to be placed in Canis and if $C$. simensis, $C$. mesomelas and $C$. adustus were to be placed in Dusicyon the hierarchic structure would still be rather weak. The overlap between the range of similarity at family and subfamily level is not so high because of the low similarity of Otocyon megalotis and the three members of the Simocyoninae with all other canids.

To enable impressions from the two-dimensional plots to be checked against actual similarity values a table of mean similarities between and within genera was prepared (Table I). The mean similarities of Fennecus and Urocyon with members of Vulpes are in bold print, as are those of Atelocynus and Cerdocyon with members of Dusicyon. Apart from some distortion in Fig. 2 the plots are in good agreement with the table of mean similarities. 

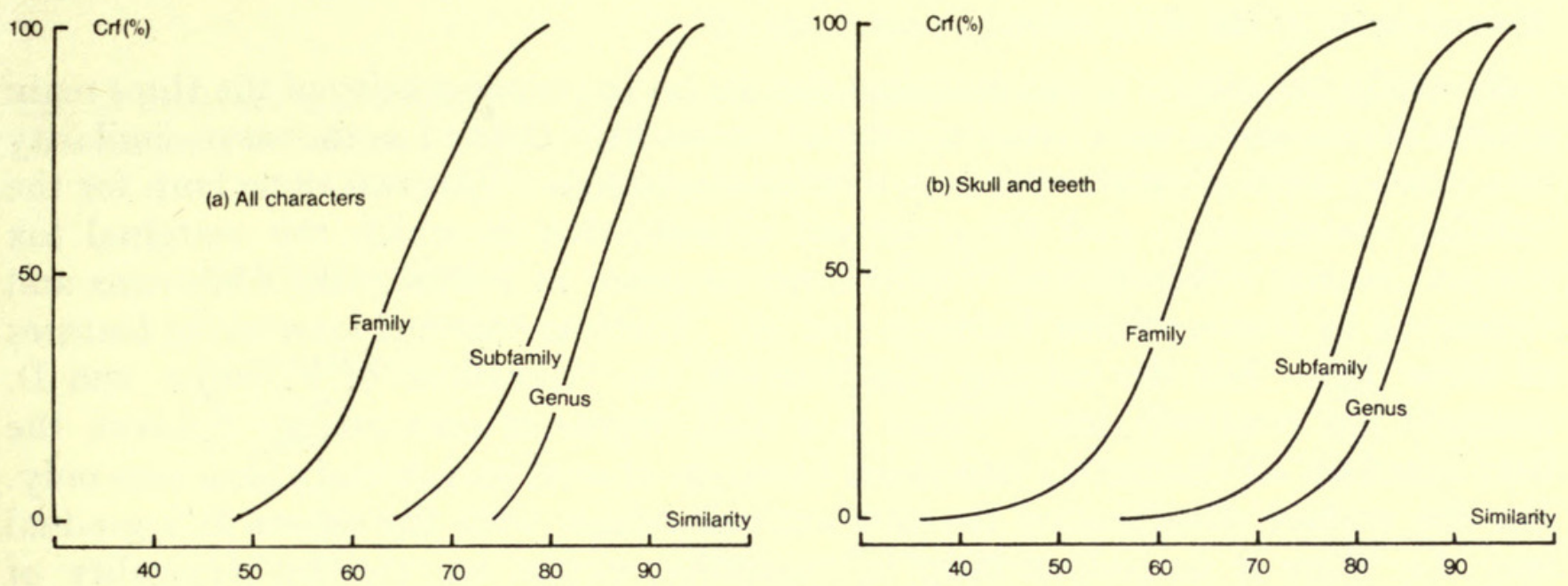

FIG. 7. Cumulative relative frequencies (Crf) of similarity values corresponding to each rank for the existing classification: a. all characters; b. skull and teeth only.

\section{TABLE I}

Mean similarities between and within genera of the existing classification

(a) All characters

Vulpes

Canis

Dusicyon

Alopex

Fennecus

Urocyon

Nyctereutes

Atelocynus

Cerdocyon

Chrysocyon

Speothos

Cuon

Lycaon

Otocyon
I $86 \cdot 9$

$\begin{array}{llll}2 & 78 \cdot 0 & 83.9\end{array}$

$\begin{array}{llll}3 & 86 \cdot 0 & 83.4 & 90 \cdot 5\end{array}$

$\begin{array}{llll}4 & 79 \cdot 2 & 74 \cdot 2 & 79 \cdot 0\end{array}$

$\begin{array}{lllll}5 & \mathbf{8 5} \cdot 1 & 72 \cdot 0 & 83.6 & 78 \cdot 2\end{array}$

$\begin{array}{llllllr}6 & 85.0 & 74.8 & 84.5 & 74.4 & 82.5 & * \\ 7 & 70 \cdot 6 & 70 \cdot 9 & 73.3 & 72 \cdot 2 & 68 \cdot 4 & 73 \cdot 3\end{array}$

$\begin{array}{llllllll}8 & 75 \cdot 7 & 79 \cdot 3 & \mathbf{8 2 . 2} & 69 \cdot 6 & 72 \cdot 4 & 79 \cdot 3 & 78 \cdot \mathbf{I}\end{array}$

$\begin{array}{lllllllll}9 & 78 \cdot 0 & 79 \cdot 4 & \mathbf{8 4 . 8} & 72 \cdot 9 & 76 \cdot 2 & 82 \cdot 1 & 76 \cdot 8 & 86 \cdot I\end{array}$

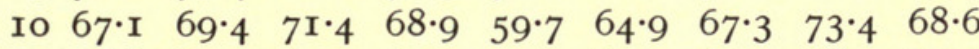

II $\begin{array}{llllllllll}58 \cdot 6 & 6 \mathrm{I} \cdot 9 & 63 \cdot 3 & 6 \mathrm{I} \cdot \mathrm{I} & 53 \cdot \mathrm{I} & 6 \mathrm{I} \cdot 5 & 65 \cdot 9 & 68 \cdot 2 & 60 \cdot 0 & 53 \cdot 8\end{array}$

$\begin{array}{llllllllllll}\text { I2 } & 70 \cdot 0 & 75 \cdot 5 & 75 \cdot 6 & 74 \cdot 7 & 69 \cdot 3 & 7 \mathrm{I} \cdot 0 & 7 \mathrm{I} \cdot 9 & 70 \cdot 4 & 69 \cdot 9 & 65 \cdot 3 & 73 \cdot 5\end{array}$

$\begin{array}{lllllllllllll}\text { I3 } & 57 \cdot 6 & 62 \cdot 9 & 6 \mathrm{I} \cdot 4 & 6 \mathrm{I} \cdot \mathrm{I} & 5 \mathrm{I} \cdot 9 & 55 \cdot 6 & 57 \cdot \mathrm{I} & 56 \cdot 6 & 53 \cdot 2 & 50 \cdot 0 & 67 \cdot 9 & 69 \cdot 7\end{array}$

$\begin{array}{llllllllllllll}14 & 70 \cdot 7 & 63.2 & 68 \cdot 3 & 69 \cdot 8 & 7 \mathrm{I} \cdot 6 & 72 \cdot 6 & 70 \cdot 8 & 67 \cdot 0 & 64 \cdot 1 & 62 \cdot 6 & 5 \mathrm{I} \cdot 5 & 59 \cdot 5 & 48 \cdot 8\end{array}$ *

(b) Skull and teeth only

Vulpes

Canis

Dusicyon

Alopex

Fennecus

Urocyon

Nyctereutes

Atelocynus

Cerdocyon

Chrysocyon

Speothos

Cuon

Lycaon

Otocyon
I $87 \cdot 6$

$276 \cdot 6 \quad 85 \cdot 9$

$\begin{array}{llll}3 & 82 \cdot 9 & 8 \mathrm{I} \cdot 5 & 84 \cdot 7\end{array}$

$\begin{array}{llll}48 \cdot 1 & 79 \cdot 2 & 80 \cdot 8\end{array}$

$\begin{array}{llllll}5 & 83.0 & 64 \cdot 3 & 74.9 & 77 \cdot 0\end{array}$

$\begin{array}{llllll}6 & \mathbf{8 1} \cdot 4 & 70 \cdot 8 & 76 \cdot 2 & 80 \cdot 1 & 77 \cdot 2\end{array}$

$\begin{array}{llllllll}7 & 78 \cdot 0 & 80 \cdot 0 & 78 \cdot 7 & 82 \cdot 9 & 68 \cdot 4 & 82 \cdot 2\end{array}$

$\begin{array}{lllllllll}8 & 8 \mathrm{I} \cdot 5 & 82 \cdot 2 & \mathbf{8 5} \cdot \mathbf{6} & 78 \cdot 9 & 7 \mathrm{I} \cdot 3 & 8 \mathrm{I} \cdot 0 & 82 \cdot 0\end{array}$

$\begin{array}{lllllllll}9 & 79 \cdot 6 & 77 \cdot 8 & \mathbf{8 2} \cdot 6 & 76 \cdot 0 & 75 \cdot 3 & 79 \cdot 2 & 80 \cdot 5 & 85 \cdot 6\end{array}$

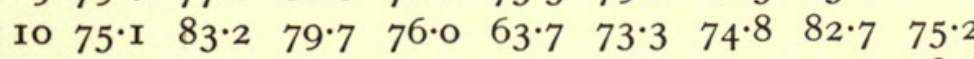

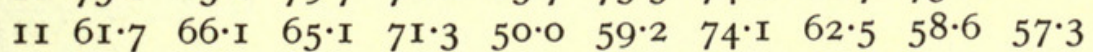

$\begin{array}{llllllllllll}\text { I2 } & 62 \cdot 0 & 70 \cdot 6 & 65 \cdot 3 & 71 \cdot 9 & 50 \cdot 5 & 58 \cdot 5 & 72 \cdot 2 & 63 \cdot 3 & 57 \cdot 6 & 63.9 & 87 \cdot 0\end{array}$

$\begin{array}{llllllllllllll}\text { I3 } & 58 \cdot 3 & 73 \cdot 2 & 62 \cdot 8 & 68 \cdot 5 & 45 \cdot 5 & 5 \mathrm{I} \cdot 5 & 68 \cdot \mathrm{I} & 62 \cdot 9 & 56 \cdot 5 & 63 \cdot 3 & 73 \cdot 7 & 80 \cdot 9\end{array}$

$\begin{array}{lllllllllllllll} & 14 & 62 \cdot 7 & 52 \cdot 2 & 56 \cdot 9 & 63 \cdot 8 & 59 \cdot 6 & 75 \cdot 9 & 66 \cdot 0 & 61 \cdot 5 & 61 \cdot 4 & 58 \cdot 4 & 43 \cdot 0 & 41 \cdot 7 & 36 \cdot 6\end{array}$ 
Homogeneity of the three main genera

To study the effects of the marginal species on the homogeneity of the three main genera the members were listed in order of 'typicality', defined as the mean similarity of a species with all other members of the same genus. This was done both for the existing classification and for a revised classification in which the marginal fox genera, Alopex, Fennecus and Urocyon, are included in Vulpes, and Atelocynus and Cerdocyon in Dusicyon (see Tables 2 and 3). There are several interesting features of these lists. For the existing classification, the typicalities of $V$. vulpes and $D$. australis are relatively low. There is a high degree of concordance between the lists based on all characters and those based on cranial and dental characters only. For the revised classification the new arrivals mingle with the others in a gradual way, i.e. there is no sudden drop in typicality, except for the low typicality of Alopex, suggesting that it is best left out of Vulpes. The homogeneity is worst for the genus Dusicyon where similarity is based on all characters, but the new range of similarity is more in line with that for Vulpes and Canis.

\section{TABLE 2}

List of members of Vulpes, Canis and Dusicyon (existing classification) in order of typicality. The measure of typicality is shown next to each species

(a) All characters

Vulpes
$V$. bengalensis
V. velox
$V$. chama
$V$. corsac
$V$. rueppelli
$V$. pallida
$V$. ferrilata
$V$. vulpes
$V$. cana

Canis

C. aureus

C. latrans

C. mesomelas

C. adustus

C. lupus

Dingo

C. simensis

Hound

D. gymnocercus

D. culpaeolus

D. fulvipes

D. griseus

D. sechurae

D. inca

D. culpaeus

D. vetulus

D. australis (b) Skull and teeth only

\begin{tabular}{ll}
\multicolumn{1}{c}{ Vulpes } \\
$V$. chama & $90 \cdot 5$ \\
$V$. velox & $90 \cdot 1$ \\
$V$. bengalensis & $89 \cdot 9$ \\
V. corsac & $88 \cdot \mathbf{1}$ \\
$V$. pallida & $88 \cdot 0$ \\
$V$. rueppelli & $87 \cdot 4$ \\
$V$. vulpes & $87 \cdot 2$ \\
V. cana & $84 \cdot 8$ \\
$V$. fervilata & $82 \cdot 6$
\end{tabular}

\section{Canis}

C. latrans

$88 \cdot 7$

Dingo $\quad 87 \cdot 8$

C. aureus $\quad 87 \cdot 3$

C. lupus $86 \cdot 0$

C. adustus $\quad 85.8$

C. mesomelas $\quad 85 \cdot 7$

Hound $\quad 83.6$

C. simensis $\quad 8 \mathrm{I} \cdot 9$

$82 \cdot 2$

Dusicyon

$93 \cdot 2$

$9 \mathrm{I} \cdot 8$

$9 \mathrm{I} \cdot 3$

$9 I \cdot I$

$90 \cdot 8$

$90 \cdot 4$

$90 \cdot 0$

$89 \cdot 3$

$86 \cdot 2$

\section{Dusicyon}

D. gymnocercus

$88 \cdot 8$

D. culpaeolus

D. fulvipes

D. sechurae

D. griseus

D. inca

D. australis

D. culpaeus

D. vetulus

$87 \cdot 5$

86.4

$85 \cdot 3$

$85 \cdot \mathrm{I}$

83.3

$82 \cdot 7$

$82 \cdot 5$

$80 \cdot 4$ 


\section{TABLE 3}

List of members of Vulpes plus Alopex lagopus, Fennecus zerda and Urocyon cinereoargenteus; also members of Dusicyon plus Atelocynus microtis and Cerdocyon thous. Both lists in order of typicality with the measure of typicality shown next to each species

(a) All characters

Vulpes
$V$. bengalensis
$V$. chama
$V$. velox
$V$. corsac
$V$. rueppelli
$V$. pallida
$F$. zerda
$U$. cinereoargenteus
$V$. ferrilata
$V$. vulpes
$V$. cana
A. lagopus

Dusicyon

D. gymnocercus

D. fulvipes

D. culpaeolus

D. griseus

D. sechurae

D. inca

D. culpaeus

D. vetulus

D. australis

C. thous

A. microtis (b) Skull and teeth only

\section{Vulpes}

$\begin{array}{lll}89 \cdot 2 & \text { V. chama } & 89 \cdot \mathrm{I} \\ 88 \cdot 3 & \text { V. bengalensis } & 88 \cdot 7 \\ 88 \cdot 3 & \text { V. velox } & 88 \cdot 3 \\ 87 \cdot 4 & \text { V. pallida } & 87 \cdot \mathrm{I} \\ 87 \cdot \mathrm{I} & \text { V. corsac } & 87 \cdot 0 \\ 86 \cdot 9 & \text { V. rueppelli } & 86 \cdot 8 \\ 84 \cdot 2 & \text { V. vulpes } & 86 \cdot 2 \\ 83 \cdot 8 & \text { V. cana } & 83 \cdot 8 \\ 83 \cdot \mathrm{I} & \text { A. lagopus } & 83 \cdot \mathrm{I} \\ 82 \cdot 0 & \text { F. zerda } & 8 \mathrm{I} \cdot 9 \\ 8 \mathrm{I} \cdot 4 & \text { U. cinereoargenteus } & 80 \cdot 9 \\ 78 \cdot 7 & \text { V. ferrilata } & 79 \cdot 8\end{array}$

Dusicyon

$9 \mathrm{I} \cdot 5$

$90 \cdot 6$

$90 \cdot 2$

$89 \cdot 6$

$89 \cdot 4$

$89 \cdot I$

$88 \cdot 3$

$87 \cdot 9$

$85 \cdot 0$

$85 \cdot 0$

$82 \cdot 6$

$\begin{array}{ll}D . \text { gymnocercus } & 88 \cdot 8 \\ D . \text { culpaeolus } & 87 \cdot 4 \\ D . \text { fulvipes } & 86 \cdot 7 \\ \text { A. microtis } & 85 \cdot 6 \\ D . \text { sechurae } & 85 \cdot 3 \\ \text { D. griseus } & 84 \cdot 9 \\ D . \text { inca } & 83 \cdot 0 \\ \text { C. thous } & 82 \cdot 9 \\ D . \text { australis } & 82 \cdot 7 \\ D . \text { culpaeus } & 8 \mathrm{I} \cdot 9 \\ D . \text { vetulus } & 80 \cdot \mathrm{I}\end{array}$

\section{Automatic classification}

A natural question to ask at this stage is what happens if the 37 species are grouped using the 666 similarities with some standard linkage algorithm? The choice of linkage algorithm is never easy (see Sneath \& Sokal, I973, for a full discussion) ; several were tried and an average linkage method, equivalent to the way the dendrogram of Fig. 6 was constructed, was chosen : two groups merge at level S if the mean similarity between pairs of species, one from each group, is greater than or equal to S. A sensible name for this algorithm would be 'weighted average linkage' because the mean similarity between groups takes account of the sizes of the groups. Unfortunately 'weighted' has other connotations in taxonomy and so the term 'centroid linkage' is used instead. The reader should be warned that the terminology in Sneath \& Sokal is different (I973: 235).

The results of the algorithm are shown in Fig. 8a, b. For both 'all characters' and 'skull and teeth only' the dendrograms retain the more homogeneous parts of the main groups. At a higher level some odd combinations occur, e.g. D. australis with 

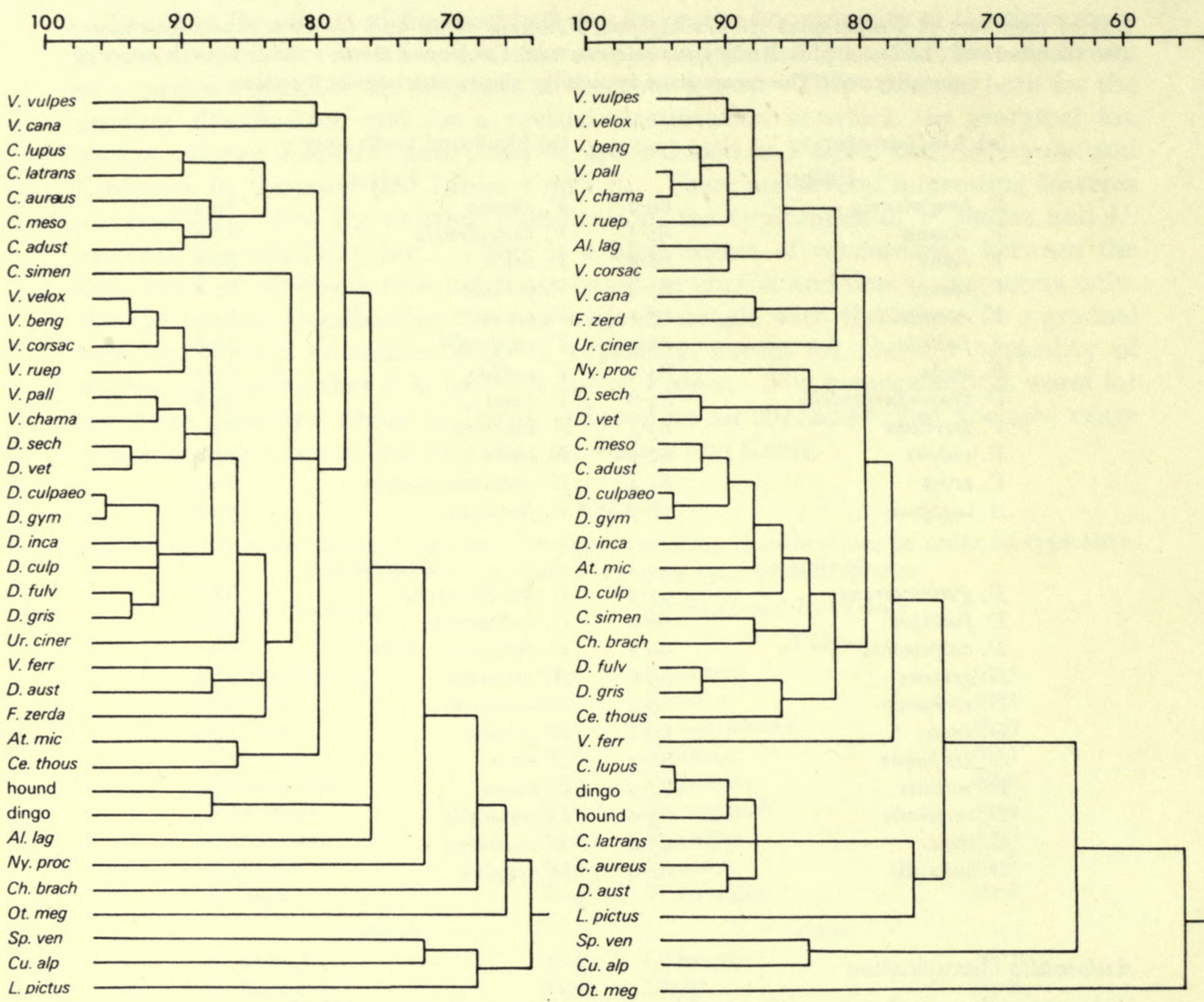

FIg. 8. Centroid linkage dendrogram : a. (left) all characters ; b. (right) skull and teeth only.

$V$. ferrilata which then join with the Vulpes and Dusicyon groups. Such oddities are common in average linkage dendrograms because small changes in similarity can cause large changes in the dendrogram. Another disadvantage is that the dendrogram as such gives no indication of how well a hierarchy fits the data; further analysis along the lines followed for the existing classification would be necessary. In general, the two-dimensional plots provided a much better way of looking at the relationships between species than the dendrograms from automatic classification algorithms. 


\section{GENERAL TAXONOMIC CONCLUSIONS}

Before drawing any general taxonomic conclusions from this analysis of phenetic relationships it is necessary to consider any other sources of relevant data that were not taken into account in the numerical analysis. Additional evidence might, for example, be forthcoming from the fossil record of the family, from studies of karyology, from immunology, from parasitology or from the results of attempted interbreeding, although it was believed that none of these categories of data could usefully be incorporated into the numerical analysis.

In practice the data from these additional sources proved to be so scanty that they contribute almost nothing to the problems of classification above the species level. The fossil history of the Canidae has been discussed by Matthew (I930), Romer (I955), Radinsky (I973) and Todd (I970). Data on chromosome numbers are summarized by Chiarelli (I975) who also tabulated the authorities for intergeneric hybrids. Further information on interspecific interbreeding was listed by Gray (I972). The species of lice that have been found on members of the canid family are presented in the Appendix (p. I94).

The general conclusion that emerges from the various forms of numerical analysis is that the majority of species, including most species of Canis, Dusicyon and Vulpes, form a large cluster with complex interrelationships and no major discontinuities, surrounded by a number of more or less distinctive and isolated species. To consider these isolated species first, the most distinctive is undoubtedly Lycaon pictus whose similarity to its 'nearest neighbour' is only $7 \mathrm{I}$. Next in order of separation come Speothos venaticus (73), Otocyon megalotis (76), Nyctereutes procyonoides (78), Cuon alpinus (79), Chrysocyon brachyurus (80) and Alopex lagopus (82). These are currently considered to represent monotypic genera except that the last (A. lagopus) is sometimes included in Vulpes. All the other species that have at one time or another been considered distinctive enough to warrant generic separation have 'nearest-neighbour' values of over 85 and are therefore no more distinctive than many species that are consistently classified within the large genera. We can therefore conclude that the species detailed above should continue to rank as monospecific genera, namely Lycaon, Speothos, Otocyon, Nyctereutes, Cuon, Chrysocyon and Alopex. The last of these is the least distinctive, and the skull and teeth show a very high degree of similarity to certain species of Vulpes, especially $V$. corsac. On the basis of all characters, however, it is clearly the most distinctive of the foxes, as shown for example by the low 'typicality' in Table 3, and there are therefore reasonable grounds for retaining it as a monospecific genus.

We can now proceed to consider whether there is justification for grouping any of these distinctive genera at subfamily level. The only such grouping with any claim to consideration seems to be the one that is currently employed, namely the grouping of Lycaon, Cuon and Speothos as a subfamily, contrasting with the remainder. Although many of the similarities between these are higher than between them and other species, they are nevertheless very low, ranging from 73.5 between Cuon and Speothos to 68 between Lycaon and Speothos. In contrast Cuon has a mean similarity of 76 with species of Dusicyon. In addition it must be remembered that 
many of the individual similarities are simply due to the shared absence of a specialized character. The higher similarity of skull and teeth between Cuon and Speothos (87) might support such a grouping but in general it seems that the similarities between these three genera (or any two of them) are so tenuous that no useful purpose is served by uniting them within a subfamily. The case for subfamily rank of any other genus is equally tenuous, e.g. Otocyon has an overall similarity of 73 with Urocyon cinereoargenteus which is normal for intergeneric similarities (Table I).

All the remaining species that have been given generic rank emerge from this analysis as an integral part of the main cluster of species and there appear to be no grounds for continuing to place any of them in monospecific genera. These are Fennecus and Urocyon which fall clearly within Vulpes; and Cerdocyon and Atelocynus which fall so close to Dusicyon that it seems reasonable to include them (Figs I and 5, Table 3). The status of all these is considered in more detail in the systematic section.

The question of the recognition of generic limits within the Canis/Vulpes/Dusicyon complex is more difficult. No objective analysis of the results of this study would produce these three genera as presently composed but nor would it produce any other clear-cut grouping of species. On the other hand, the retention of these genera does not produce any serious anomalies and they are capable of definition. They are therefore retained here. Arising from a detailed study of the South American species, Langguth (I975) proposes to recognize Cerdocyon thous, Atelocynus microtis and Lycalopex vetulus as additional, monotypic, 'differentiated' genera and to include the remaining species of Dusicyon in Canis. These proposals are not greatly at variance with our conclusions although the distinctiveness of these 'differentiated' species seems marginal, and if Dusicyon were merged with Canis it would be difficult to argue that Vulpes should not be treated likewise.

This examination of the family Canidae as an integrated whole has enabled some anomalies in the taxonomy to be straightened out. It is hoped that it has also enabled some misconceptions to be erased. Perhaps the most notable of these is the belief that the common fox, Vulpes vulpes, is a typical representative of its genus. This belief has led to the classification of those species of fox that do not conform with $V$. vulpes in separate genera. In fact the typical fox is Vulpes bengalensis and $V$. vulpes should be considered almost as an aberrant species. When this fact is recognized the classification of the genus becomes more straightforward.

The extinct Falkland island wolf, Dusicyon australis, is seen to be a very anomalous species but lack of adequate specimens precludes any very clear assessment of its affinities.

The revised classification proposed is presented below, and the relationships of each genus and species are considered in more detail in the systematic account that follows. In this list the 'species' of Dusicyon that are indented may be conspecific with the species listed above them, but this is a question that can only be answered by more detailed study of distribution and variation in South America. 
Proposed classification of the family Canidae:

\begin{tabular}{|c|c|}
\hline Canis lupus & Wolf \\
\hline (Canis rufus) & (Red wolf) \\
\hline Canis (domestic) & Dingo and domestic dogs \\
\hline Canis latrans & Coyote \\
\hline Canis aureus & Golden jackal \\
\hline Canis mesomelas & Black-backed jackal \\
\hline Canis adustus & Side-striped jackal \\
\hline Canis simensis & Ethiopian jackal \\
\hline Vulpes vulpes & Common or red fox \\
\hline Vulpes corsac & Corsac fox \\
\hline Vulpes ferrilata & Tibetan sand fox \\
\hline Vulpes bengalensis & Bengal fox \\
\hline Vulpes cana & Blanford's fox \\
\hline Vulpes rueppelli & Sand fox \\
\hline Vulpes pallida & Pale fox \\
\hline Vulpes zerda & Fennec fox \\
\hline Vulpes chama & Cape fox \\
\hline Vulpes velox & Kit fox \\
\hline Vulpes cinereoargenteus & Grey fox \\
\hline (Vulpes littoralis) & (Island grey fox) \\
\hline Alopex lagopus & Arctic fox \\
\hline Otocyon megalotis & Bat-eared fox \\
\hline Nyctereutes procyonoides & Raccoon dog \\
\hline Dusicyon australis & $\begin{array}{l}\text { Falkland Island wolf-extinct since } \\
\text { c. } 1880\end{array}$ \\
\hline Dusicyon culpaeus & Colpeo fox \\
\hline Dusicyon culpaeolus & \\
\hline Dusicyon gymnocercus & Azara's fox \\
\hline Dusicyon inca & \\
\hline Dusicyon griseus & Argentine grey fox \\
\hline Dusicyon fulvipes & Chiloe fox \\
\hline Dusicyon sechurae & Sechura desert fox \\
\hline Dusicyon vetulus & Hoary fox \\
\hline Dusicyon thous & Common zorro \\
\hline Dusicyon microtis & Small-eared zorro \\
\hline Chrysocyon brachyurus & Maned wolf \\
\hline Speothos venaticus & Bush dog \\
\hline Cuon alpinus & Dhole \\
\hline Lycaon pictus & Hunting dog \\
\hline
\end{tabular}

\section{SYSTEMATIC ACCOUNT \\ Genus $C A N I S$ L.}

Type species Canis familiaris L., the domestic dog.

For the purposes of this analysis the genus has been taken as comprising six species plus two domesticated forms, the feral dingo as an example of a primitive domestic breed and the bloodhound which exemplifies advanced domestication without gross abnormalities. These two dogs have been treated as separate 'species' 
on an equal level with the wild species. Although Canis familiaris is the type species for the genus the name has not been used in this work because we believe that formal zoological nomenclature should be avoided in naming domestic animals (see Groves, I97I).

Recent classifications of the Canidae usually include the three groups, wolves, coyote and jackals, within the genus $C$ anis and the results of this numerical taxonomy show that this is consistent with the phenetic relationships of the species. Heller (I9I4) separated the jackals from the wolves and coyote in the genus Thos Oken, and this classification was followed by Allen (I939). Heller defined the genus Thos as a group of Canidae having long slender Vulpes-like canines, small outer incisors, small carnassials, upper molar teeth with well-marked cingula and the fourth lower premolar with a minute extra cusp on its hinder border. $\mathrm{He}$ distinguished the genus Canis by the much thicker and shorter canines, greatly enlarged outer incisors, large carnassials, molars without a definite cingulum, and the fourth lower premolar without a third cusp on its posterior border. None of these characters is definitive and they are all very variable in their development. It is therefore more appropriate to include the jackals within the genus Canis. Allen (I939) also afforded separate generic status to the Ethiopian jackal, Canis simensis, placing it in the genus Simenia Gray. This somewhat aberrant canid appears from the results of the numerical taxonomy to be phenetically close to the genus Dusicyon but the skull has a high similarity with that of Canis adustus and we therefore include it with the jackal group in the genus Canis. There is no evidence to support the suggestion of Brink (I973) that $C$. adustus should be placed in a separate genus.

The wolf is the largest species within the family and it is separated from the coyote and jackals by its more highly evolved social behaviour patterns that are closely reflected in its descendant, the domestic dog. The skull in all members of the genus has well-defined diagnostic features. It is always rather heavy and has large frontal sinuses. The temporal ridges are close together and are often fused into a strong interparietal crest. With the exception of Canis simensis, the facial region is relatively shorter than in the genera Vulpes or Dusicyon. The canine teeth are robust and the carnassials are relatively large. There is no subangular lobe to the mandible.

The genus is very flexible in its habitat preferences, again with the exception of C. simensis which is confined to montane areas of Ethiopia, where it is nearly extinct. Most wild Canis species have wide distributions but they are not found in areas of dense tropical rain forest. The domestic dog has been taken to all parts of the world that are inhabited by man and it is presumed that the dingo was taken to Australia by man during prehistoric times. The wild members of the genus Canis are distributed throughout Europe, Asia, North America and Africa.

\section{Canis lupus L., I758}

Wolf

Distribution. Widespread in the northern hemisphere and as a species without particular habitat preferences. May be found in tundra regions, woodland, open 
plains or the edges of desert areas, from sea level to more than $3000 \mathrm{~m}$. As their habitat has been restricted the wolf populations have been moved into progressively more inhospitable regions. Formerly widespread throughout the temperate areas of the northern hemisphere, but now extinct in western Europe except for small dwindling populations in Portugal, Spain, Italy, Sicily and Scandinavia. Still widely distributed in the U.S.S.R. and extending eastward into Mongolia, western China, Korea, Tibet and southwards into India. There are still small numbers in southwestern Asia. Widespread in Canada and Alaska but extinct in the U.S.A. except in wildlife parks. Classified as a vulnerable species by the Red data book (Goodwin \& Holloway, I972).

DEsCRIPTION. The largest member of the family. Body heavy with large head and long legs. Tail long and bushy. Ears erect. Fur very thick and with long guard hairs, especially in the arctic regions of the range. Pelage characters very variable - may be white, tawny, grey or black, but grey agouti with some tawny is the predominant colouring. Legs, ears, muzzle and underparts are usually reddish or pale. There is often a dark saddle and a dark patch over the tail gland. Highly social. Hunt large prey in packs of between two and eight individuals, although larger groups may be found in exceptional circumstances (Mech, I970).

Skull large with very well-developed interparietal crest. Massive jaws with powerful canine and carnassial teeth. Facial region long. Bullae large.

Systematic position. Percentage similarity to 'near neighbours' :

All characters

Canis latrans

Canis aureus

Bloodhound

Dusicyon culpaeolus

Canis mesomelas
Skull and teeth only

Dingo

Bloodhound

Canis aureus

Canis latrans

Dusicyon australis
$94 \cdot 7$

$92 \cdot 4$

$89 \cdot 2$

$89 \cdot \mathrm{I}$

$87 \cdot 5$

It is of great interest that the numerical results show such a close phenetic similarity between Canis lupus, the dingo and the bloodhound, especially as this breed of dog bears little superficial resemblance to the wolf. This is discussed in the following sections on the dogs. The wolf is also closely related to the coyote, Canis latrans, and it may be mentioned here that there is evidence to suggest that Canis rufus Audubon \& Bachman, I85I (formerly known as Canis niger Bartram, I79I - see Paradiso \& Nowak, I972), which has not been included in this analysis, is a composite species resulting from wolf-coyote hybrids (see Lawrence \& Bossert, I967, I975 ; Mech, I970 ; Paradiso, I97I ; Gipson et al., I974).

Remarks. Canis lupus (when not persecuted by man) is one of the most widespread and successful of large mammals. It is exceedingly variable in size, pelage and body proportions, but probably not in its behaviour patterns, over its wide range. For the purposes of this analysis four specimens were chosen for measurement and scoring of characters, the localities being selected to cover as much as possible of the range. The localities were Sweden, British Columbia, Spain and India. Indian wolves are considerably smaller than northern animals and have a shorter coat. 
In order that a predator may kill its prey efficiently it must be either larger than or approximately the same size as the prey or it must hunt in a group and use a concerted effort to obtain its food. The wolf is adapted to feed on animals that are much larger than itself and the features that distinguish it from other canids are all integrated with this predator-prey relationship which has resulted in a highly evolved social system. The wolf pack is held together by strong social bonds and the suppression of aggression between individual members.

So much work has been carried out in recent years on the social behaviour and signals of communication in the wolf and it is now so well known that it will not be repeated here (amongst others, see Crisler, I959; Fox, I970, I97I, I975; Mech, I970; Pulliainen, I967; Schenkel, I967; Scott, I967; Woolpy \& Ginsburg, I967). It may be said, however, that the basic difference between the wolf and the other highly social canid, Lycaon pictus, is that the wolf pack is based on a hierarchical system (as in man) whereas in L. pictus the pack is held together by individual dominant and submissive relationships, with no established hierarchy and no highly evolved system of communication by facial and body signals (Fox, I970; see p. I8I).

\section{Canis (domestic)}

\section{Dingo}

Distribution. Open country throughout most of the continent of Australia except Tasmania. Absent from central New South Wales and the northern agricultural districts of western Australia (Ride, I970).

Description. A medium to large-sized dog. Usually a tawny-yellow colour but may show other colour variations including black. There is often a white tip to the tail and white feet. Of I5 skins examined in the British Museum only one had the first digit on the hind feet represented by a claw ('dew claw'). As noted by Lönnberg (I9I6), a vestigial first digit may be very occasionally present in wild canids but it is certainly exceptional. Mivart (I890, p. iv) stated that no wild species of canid ever has this first digit and we have not noticed any example of it, but it is relatively common in domestic dogs. The same dingo skin that had 'dew claws' (no. 25.8.I.9) had a slight dark patch on the dorsal side of the tail in the position of the tail gland. Hildebrand (I952b) quoted the belief that the tail gland is not found in the domestic dog, but further observation might well show that it can be present.

Skull like that of a small wolf. Teeth large and evenly spaced, carnassials strongly developed. Bullae large but rather flatter than in the wolf. Frontal sinuses well developed.

Systematic position. Percentage similarity to 'near neighbours' :

All characters

Bloodhound

Dusicyon australis

Canis aureus

Dusicyon inca

Dusicyon sechurae
$88 \cdot 7$

$87 \cdot 1$

$84 \cdot 0$

$83 \cdot 5$

$83 \cdot 3$
Skull and teeth only

Canis lupus

Canis latrans

Canis aureus

Dusicyon australis

Bloodhound
$94 \cdot 7$

$9 \mathrm{I} \cdot 7$

$9 \mathrm{I} \cdot 5$

$9 \mathrm{I} \cdot \mathrm{I}$

$90 \cdot 9$ 
The dingo is a fascinating relic of the primitive domestic dogs that must have been widespread in Asia during the early Holocene. It is not a biological species but a feral dog that is closely related to the New Guinea singing dogs and Indian pariah dogs. It is probable that these dogs are all directly descended from the Indian wolf, Canis lupus pallipes Sykes, I83I. This supposition is supported by the 'near neighbours' table for skull characters which shows a similarity of nearly 95 for the dingo and the wolf. The only other taxa in this analysis that are linked at this high level of similarity are Dusicyon gymnocercus with Dusicyon culpaeolus (which may well not be separate species) and Vulpes chama with Vulpes pallida. Corbett \& Newsome (I975) have made a preliminary analysis of the social behaviour of the dingo in the wild.

On the two-dimensional plots the dingo, wolf and bloodhound can be seen to be closely linked, and on the 'near neighbours' table for cranial and dental characters the dingo is linked with the 'typical' species, Canis aureus and Canis latrans, at a similarity of just under 92 .

The enigmatic position of Dusicyon australis, the extinct Falkland Island wolf, in association with the dingo and bloodhound is discussed in the section on that species (p. I66).

\section{Canis (domestic)}

\section{Bloodhound}

OrIGIN. The bloodhound is probably descended from the French black and tan hounds that were bred for several hundred years at the St Hubert Monastery in the Ardennes. It has been established as a British breed since the Medieval period.

Description. A pure-bred hound of ancient descent. Large, massively built, short-coated with long pendulous ears, a wrinkled face and long tail. May be black and tan, all tan or red and tan; the skin that was used for this project was a mottled grey and tawny. The first digit on the hind foot (hallux) is sometimes developed as a 'dew claw' as is common in all domestic dogs. No black patch on the dorsal part of the tail in the position of the tail gland. Like all domestic dogs the bloodhound is a highly social animal.

Skull typically 'hound-like'. Facial region long with heavy jaws. Teeth large and well-spaced but carnassial teeth relatively short. Postorbital processes of the frontal bones much swollen so that the profile of the skull has a marked 'stop'. This is a characteristic feature of advanced domestication in the dog and is associated with enlarged frontal sinuses. The reduced carnassial teeth and rather small flat bullae are also features of domestication. The interparietal crest is usually welldeveloped.

Systematic position. Percentage similarity to 'near neighbours' :

All characters

Dingo

Dusicyon australis

Canis lupus

Canis aureus

Canis latrans
$88 \cdot 7$

$85 \cdot 9$

84.0

$83 \cdot 5$

$8 \mathrm{I} \cdot \mathrm{I}$
Skull and teeth only

Canis lupus

Dingo

Canis aureus

$92 \cdot 4$

$90 \cdot 9$

Canis latrans

Dusicyon australis
$86 \cdot 3$

$85^{\circ} 4$

$85 \cdot 3$ 
It has been known for some years, from studies of social and agonistic behaviour, that the domestic dog is more likely to be descended from the wolf than from the coyote or the jackal (see, for example, Scott, I967). It is most interesting that our numerical results, which included only a few behavioural characters out of the total of 90, so closely corroborate this deduction. Previous work on the osteological differences between the skulls of dogs and the wild Canis species has often failed to show clear distinction between the different groups. The present analysis shows that the skull of the bloodhound is phenetically closer to that of the wolf and the dingo than it is to the skulls of coyote or jackal. The two-dimensional plots and centroid linkage dendrogram also show the same relationships.

It is surely rather remarkable that the dingo and the bloodhound, which bear so little superficial resemblance to each other and have such widely separated origins, should be so phenetically similar. The inference must be that they share a common ancestor in the wolf.

\section{Canis latrans Say, $\mathrm{I} 823$}

Coyote

Distribution. Widespread in North America. Formerly confined to areas west of the Mississippi river from southern Canada to central Mexico; now extending to Alaska and Costa Rica but still not very common in the eastern regions. The preferred habitat is open plains and desert and the coyote is not found in damp tropical areas (Hershkovitz, I972 : 359 ; Miller \& Kellogg, I955 ; Van Wormer, I964).

Description. 'Wolf-like' but smaller. An adult North American male wolf weighs an average of $45 \mathrm{~kg}$, whereas the average weight of a male coyote is only I2 $\mathrm{kg}$ (Mech, I970; Van Wormer, I964). The coyote stands nearly as high at the shoulder as the wolf but it is much more lightly built with long slender legs, large ears and a bushy tail. Pelage characters are variable as with all canids that cover a wide geographical range. The coat is usually long and has an overall buffy-grey colour with long dark-banded guard hairs. Legs and sides may be fulvous. Underparts and chin pale or nearly white. Tip of tail usually black. Not highly social but may live in family groups and take part in communal howling. Feeds on rodents, small game animals and birds.

Size of skull between that of a small wolf and a jackal. The teeth, especially the canines and carnassials, well developed. Interparietal crest present but not so pronounced as in the wolf. Bullae rounded. Differences between the skulls of wolves, coyotes and domestic dogs have been analysed by Lawrence \& Bossert (I967).

Systematic position. Percentage similarity to 'near neighbours' :

All characters

Canis lupus

Canis aureus

Dusicyon culpaeolus

Canis mesomelas

Dusicyon culpaeus
$90 \cdot 0$

$89 \cdot 7$

$87 \cdot 5$

$87 \cdot 4$

$87 \cdot 2$
Skull and teeth only

Dingo

Canis mesomelas $\quad 90 \cdot 8$

Canis lupus $\quad 89 \cdot \mathrm{I}$

Canis aureus $\quad 88.9$

Dusicyon australis $\quad 88 \cdot 9$ 
On phenetic characters the coyote lies between the wolf and the jackals. It is unlikely that the coyote has played any great part in the origins of the domestic dog. The American Indians may have crossed their dogs with coyotes from time to time but it is probable that this had only a local effect. Mengel (I97I) has shown that gene flow from dogs to wild populations of Canis latrans (and also to Canis lupus) is unlikely to occur because of a phase shift in the breeding time of the hybrids. This prevents further reproduction after the first generation. An interesting aspect of Mengel's work was his demonstration that wild male coyotes are only fertile for about two months in the year whereas male domestic dogs are always in breeding condition.

\section{Canis aureus $\mathrm{L}$., I758}

\section{Golden jackal, Asiatic jackal}

Distribution. Wooded and open country in the Balkan states, Romania, countries of the eastern Mediterranean, including Greece, Libya, Egypt and westwards into Morocco. South to Senegal, the Sudan, Somalia, Ethiopia and Kenya. Eastwards through western Asia, the Middle East, Baluchistan and Sind. Throughout the peninsula of India to Ceylon and east to Assam, Burma and Thailand (Ellerman \& Morrison-Scott, I966).

DESCRIPTION. Like the coyote, this jackal covers a very wide geographical area and it is very variable in size and pelage characters. The skins in the British Museum from localities in S.W. Asia and S.E. Europe were described in detail by Pocock (1938). In general the fur is rather coarse and not very long. The dorsal area is mottled black and grey. The head, ears, sides and limbs may be tawny or rufous, the underparts pale ginger or nearly white. Tail tip black. Feeds on small animals, carrion, insects and some fruit and vegetable matter. Not highly social but will hunt in packs. An exceptionally large subspecies, C.a. lupaster Hemprich \& Ehrenberg, I833, occurs in Egypt and Libya ; a specimen of this subspecies was included in the analysis.

Skull like that of a very small wolf, with well-developed, high-crowned teeth. Interparietal crest present. Facial region somewhat short. There is often a well-marked cingulum on the labial side of $\mathbf{M}^{1}$.

Systematic position. Percentage similarity to 'near neighbours' :

All characters

Canis mesomelas

Canis latrans

Dusicyon australis

Canis adustus

Canis lupus
$89 \cdot 9$

$89 \cdot 7$

$88 \cdot 8$

$88 \cdot 7$

$87 \cdot 7$
Skull and teeth only

$\begin{array}{ll}\text { Dingo } & 9 \mathrm{r} \cdot 5 \\ \text { Dusicyon australis } & 9 \mathrm{r} \cdot 4 \\ \text { Canis lupus } & 89 \cdot \mathbf{r} \\ \text { Canis latrans } & 88 \cdot 9 \\ \text { Canis mesomelas } & 88 \cdot 3\end{array}$

For the all-characters similarity Canis aureus is the most typical of the Canis species (Table 2) and this is in fact obvious from one look at this jackal, for it is of 
medium size and has no outstanding features. The pelage is typical of the family and the wide range that it covers precludes specialization. The skull of $C$. aureus is not as similar to the African jackals, Canis mesomelas, Canis adustus and Canis simensis, as it is to the dingo, wolf or coyote which is somewhat surprising. The position and relationships of Dusicyon australis are anomalous and are discussed in the section on that species. The behaviour of the golden jackals of the Ngorongoro Crater in Tanzania has been studied by H. \& J. van Lawick-Goodall (I970), and detailed observations were made on a pair of jackals in Israel by Golani \& Keller (1975).

\section{Canis mesomelas Schreber, $\mathrm{I} 778$}

\section{Black-backed jackal}

Distribution. Widespread in open savannah throughout eastern and southern Africa, northwards to the Sudan and west to Cameroun (Allen, I939; Ellerman et al., 1953).

Description. Distinguished by the dark saddle which extends the length of the back to the black tip of the tail. This saddle, which is mottled black and cream, contrasts strongly with the rufous sides of the body. The head and ears are also rufous flecked with white and dark hairs. The limbs are tawny or rufous, the underparts pale ginger. Underfur, except on the abdomen, consistently rufous, the colour of the saddle being due to banded black and white guard hairs. Lives alone or in small family groups. As with all species of Canis this jackal may participate in communal howling. Feeds on small prey and carrion.

Skull smaller than that of Canis aureus. Parietal crest may be poorly developed and there may be a narrow lyriform sagittal area enclosed by weak temporal ridges. Dentition, especially the canines which are rather pointed, may resemble that in the genus Dusicyon.

Systematic position. Percentage similarity to 'near neighbours' :

$\begin{array}{ll}\text { All characters } & \\ \text { Dusicyon culpaeolus } & 92 \cdot 9 \\ \text { Dusicyon gymnocercus } & 9 \mathrm{I} \cdot 5 \\ \text { Canis adustus } & 90 \cdot 3 \\ \text { Canis aureus } & 89 \cdot 9 \\ \text { Dusicyon inca } & 88 \cdot 7\end{array}$

Skull and teeth only

Canis adustus $\quad 92 \cdot 7$

Dusicyon australis $\quad 92 \cdot 5$

Dusicyon culpaeolus $\quad 91 \cdot 9$

Canis latrans $\quad 90 \cdot 8$

Dusicyon gymnocercus $90 \cdot 7$

The two-dimensional plots and centroid linkage dendrograms show that Canis mesomelas and Canis adustus are closely related and they have a similarity of 92 on cranial and dental characters.

REMARKs. The black-backed jackal is looked upon as vermin in South Africa and it is persecuted by farmers because it kills sheep. 
Canis adustus Sundevall, I 846

Side-striped jackal

Distribution. Covers the same regions as Canis mesomelas, but prefers a heavier density of vegetation and wooded areas. Widespread in southern and eastern Africa. Northwards into the Sudan and Cameroun (Ellerman et al., I953).

DEscription. The pelage of this jackal differs considerably from that of $C$. mesomelas and it is a larger, heavier animal. The coat is long and soft-haired. There is no marked saddle but a line of white guard hairs, followed below by a line of dark hairs, runs along each side of the body, giving the jackal its name. The underfur is ochreous, the guard hairs banded dark and white, giving a generally mottled grey appearance to the pelt. Head buffy-grey with darker grey ears. Underparts pale grey. Tail tip white. Feeds on carrion, rodents, insects and vegetable matter.

Skull slightly longer and narrower than that of $C$. mesomelas, but the teeth are smaller and less high-crowned, especially the carnassials. The bullae are smaller and flatter. Interparietal crest slightly developed.

Systematic position. Percentage similarity to 'near neighbours' :

$\begin{array}{lr}\text { All characters } & \\ \text { Canis mesomelas } & 89 \cdot 9 \\ \text { Canis latrans } & 89 \cdot 7 \\ \text { Dusicyon australis } & 88 \cdot 8 \\ \text { Canis aureus } & 88 \cdot 7 \\ \text { Dusicyon inca } & 88 \cdot 5\end{array}$

Skull and teeth only

Canis mesomelas $\quad 92 \cdot 7$

Dusicyon culpaeolus $\quad 92 \cdot 0$

Dusicyon gymnocercus $9 \mathrm{I} \cdot 5$

Canis simensis $\quad 9 \mathrm{I} \cdot 2$

Dusicyon microtis $\quad 90 \cdot 4$

As stated above, it is clear from the numerical results that Canis adustus has a high similarity with C. mesomelas. According to Van der Merwe (I953) this jackal is mainly nocturnal and feeds on smaller prey than the black-backed jackal. Certainly the relative conformation of its skull and teeth suggest that this is likely. The side-striped jackal has no reputation as a killer of sheep and consequently it is not exterminated by farmers in the same way as $C$. mesomelas. These two jackals are a good example of closely related sympatric species.

\section{Canis simensis Rüppell, I835}

Ethiopian jackal, Simien jackal

Distribution. Montane; inhabits grassland plateau areas associated with giant lobelia at an altitude of 2900 to $3900 \mathrm{~m}$ on the Simien and other mountains in central Ethiopia. Probably nearly extinct and classified as an endangered species in the Red data book (Goodwin \& Holloway, I972).

Description. Very little is known about this rare canid. The overall colour is a tawny rufous with pale ginger underfur. The chin, insides of ears, chest and 
underparts are white. There is a distinctive white band around the ventral part of the neck and the inner sides of the limbs are also white. The tail is rather short; the posterior end is dark with black ends to the guard hairs; the anterior part is white underneath and around the anus. There is no dark patch to mark the tail gland.

Skull 'jackal-like' but with an elongated facial region. Teeth, especially the upper carnassials, rather small. Canines long and sharply pointed. Interparietal crest slightly developed.

Systematic position. Percentage similarity to 'near neighbours' :

$\begin{array}{lr}\text { All characters } & \\ \text { Dusicyon gymnocercus } & 88 \cdot 5 \\ \text { Dusicyon inca } & 87 \cdot 6 \\ \text { Dusicyon culpaeolus } & 87 \cdot 3 \\ \text { Dusicyon fulvipes } & 86 \cdot \mathrm{I} \\ \text { Dusicyon culpaeus } & 86 \cdot \mathrm{I}\end{array}$

Skull and teeth only

Canis adustus $\quad 9 \mathrm{I} \cdot 2$

Dusicyon gymnocercus $89 \cdot 7$

Chrysocyon brachyurus $88 \cdot 7$

Dusicyon culpaeolus $88 \cdot 5$

Dusicyon culpaeus $\quad 86 \cdot 5$

Canis simensis is sometimes called the Simien fox. It is not, however, at all closely linked to the Vulpes group and the postorbital processes of the frontal bones do not have the little depressions that signify the lack of frontal sinuses; a character that within the Canidae is only found in the genera Vulpes, Alopex and Otocyon.

The near-neighbours tables and two-dimensional plots show a seemingly close similarity with the genus Dusicyon but it can be seen that both Canis adustus and Canis mesomelas are also close to Dusicyon, and it is possible that the numerical results for $C$. simensis are biased by lack of data on the postcranial skeleton and on behaviour. Gray (I868) placed this species in a separate genus, Simenia, and this classification was followed by Allen (I939). However, the 9I·2 similarity that the cranial and dental characters have with $C$. adustus shows that separate generic status is not justified and the species is therefore retained within the genus Canis. In general appearance the skull of $C$. simensis looks like an elongated skull of $C$. adustus, in the same way as, in the foxes, the skull of Vulpes ferrilata looks like an elongated skull of Vulpes corsac. It may be worth comment that both $C$. simensis and $V$. ferrilata are adapted to a montane environment.

\section{Genus Vulpes Frisch, I775}

Type species Canis vulpes L. I758.

The work of Frisch (I775) has been declared unavailable by the International Commission on Zoological Nomenclature (Anon., I950). This author was accepted by Simpson (I945) and is used here because the next available uses of Vulpes (Bowdich, I82I ; Fleming, I822) postdate the generic name Fennecus Desmarest, I804 (Oken, I8I6 also being unavailable, see Opinion 4I7, I956). As we propose in this classification to include Fennecus zerda with the foxes this would mean changing the generic name for the entire group of foxes from Vulpes Fleming, I822 to Fennecus 
Desmarest, $\mathrm{I} 804$ if Fleming were accepted. This change would clearly be most impractical, as Vulpes is in such general use. A proposal has therefore been submitted to the Commission to place Vulpes Frisch, I775 on the Official List of Generic Names in Zoology (Clutton-Brock \& Corbet, I975).

The genus Vulpes covers nearly the same geographical range as Canis except that there is no species of fox in central Africa. Twelve species have been included in this classification. As well as all those that are generally recognized as true foxes it has been found necessary to include the fennec fox (Fennecus zerda), and the American grey fox (Urocyon cinereoargenteus). Justification for the changes are given on p. I34 and in the sections on these species.

All the species of fox are solitary carnivores and they mostly live in burrows that they dig themselves. They prey on small mammals, birds, reptiles, insects and eggs, whilst some species feed on a considerable amount of fruit and vegetable matter. All foxes have a pointed muzzle, large erect ears and a long bushy tail. They tend to be rather low-bodied and have long, thick fur, but the wide distribution of the genus is reflected in modifications to these characters, as for example in adaptations to desert and montane conditions.

The skull of all members of the genus Vulpes is distinctive in that the frontal sinuses are only slightly developed, if present at all, and there are small depressions that can be seen and felt on the frontal bones just medially from the postorbital processes. It may be noted that the skulls of Vulpes zerda, Vulpes cinereoargenteus and Alopex lagopus show these depressions and so, incidentally, does the skull of the South African bat-eared fox, Otocyon megalotis. In all foxes the skull is slender and flattened compared to that of Canis. The temporal ridges may be nearly fused as in Vulpes vulpes or they may be indistinct and wide apart as in the desert foxes. The raised temporal ridges and rugose parietal bones of $V$. cinereoargenteus can be seen as an exaggerated form of a common character when the genus is looked at as a whole. The sagittal and parietal bones of Vulpes pallida, in fact, closely resemble those of $V$. cinereoargenteus but are, in comparison, only feebly developed.

Huxley (I880) made a comprehensive comparative study of the skulls and dentition of $V$. vulpes and Dusicyon culpaeus as a basis for his wider study of the whole family Canidae. He concluded that although the skulls of the two species were very alike there were outstanding differences in the absence or slight development of the frontal sinuses in the fox and in the relative shapes of the cranial cavities, reflecting the shape of the brain. On these differences Huxley divided the Canidae into two groups, the alopecoids which included all the true foxes, and the thooids which included Canis, Dusicyon and Lycaon. This division of the genera into two groups on the basis of brain morphology has been repeated recently by Radinsky (I973) who found distinctions in the relative size and shape of the prorean gyrus and hence in the profiles of the frontal lobes of the brain between the species of Canis and Vulpes. Radinsky, however, found that species of Dusicyon were intermediate between these two genera in the shape and size of the prorean gyrus (defined as the dorsal part of approximately the anterior two-thirds of the frontal lobe: Radinsky, pers. comm., I974). 


\section{Vulpes vulpes (L., I758)}

Common fox, red fox

Distribution. The common fox is the most widespread of all wild canids and even exceeds the wolf in its distribution. It is found in wooded and open country throughout the Palaearctic region, including North Africa, and in southeastern Asia, northern Indo-China and much of North America. The natural range has been extended by human agency, perhaps most notably into Australia.

Description. The largest member of the genus but very variable in size, as in many other characters, throughout its wide range. Typically the pelage is a rich rufous colour. The backs of the ears are black or dark brown and contrast strongly with the head and neck. There may be a black patch or mask between the nose and eyes. The insides of the ears are light in colour as are the chin and underparts. The tail, or 'brush', is very long and bushy and has a white tip. There is a dark stripe down the front of the foreleg, and the hindleg is black from the hock downwards. There are, however, many variations to this coat colour pattern and a melanistic form is quite common. A black and silver-grey variety (the silver fox) is bred in captivity for its fur.

The skull is one of the largest in the genus Vulpes, with a long narrow palatine region. An interparietal crest may be present but is not normally strongly developed. The temporal ridges lie close together. The cheek-teeth are sharp but rather small. $\mathrm{P}^{2}$ and $\mathrm{P}^{3}$ have no posterior secondary cusps. The canines are long and finely pointed.

Systematic position. Percentage similarity to 'near neighbours' :

$\begin{array}{lr}\text { All characters } & \\ \text { Vulpes bengalensis } & 87 \cdot 4 \\ \text { Vulpes velox } & 86 \cdot 5 \\ \text { Vulpes rueppelli } & 86 \cdot 3 \\ \text { Vulpes chama } & 84 \cdot 9 \\ \text { Vulpes corsac } & 84 \cdot 5\end{array}$

Skull and teeth only

$\begin{array}{ll}\text { Vulpes velox } & 9 \mathrm{I} \cdot 8 \\ \text { Vulpes bengalensis } & 9 \mathrm{I} \cdot 4 \\ \text { Vulpes corsac } & 90 \cdot 2 \\ \text { Alopex lagopus } & 89 \cdot 6 \\ \text { Vulpes chama } & 89 \cdot 2\end{array}$

Although Vulpes vulpes is the type species of the genus it bears a rather low similarity to the rest of the foxes on all characters (discussed in the section on typicalities, see p. I36), and on the two-dimensional plots it can be seen to be hardly less peripheral than Alopex lagopus, Vulpes cinereoargenteus and Vulpes zerda (Figs 2a, 3a, 5a). On cranial and dental characters, however, the common fox does lie well within the genus.

REMARKS. The common fox would undoubtedly have been domesticated by man if its solitary nature and pungent smell had not made it so intractable, for the species has had an almost symbiotic relationship with man since the prehistoric period. Fox bones are commonly found amongst Neolithic animal remains, especially in Western Asia (Clutton-Brock, I969) where foxes appear to have been an important source of meat. Their pelts remain of economic value at the present day in many parts of the world. On the other hand, since the beginnings of livestock 
husbandry the fox has preyed on domestic animals and scavenged for food around homesteads. Attempts to control the fox's depredations on livestock have developed into one of the most highly ritualized of sports. Paradoxically, hunting of the fox has been the means, not only of its preservation, but also of an increase in its distribution. Before the emigration of Europeans to North America, the common fox may have had a much more restricted distribution over the whole continent, for it is known that foxes were imported into the eastern regions in the seventeenth century (Gilmore, I946). British foxes were introduced by a hunt club into Australia in I868 (Troughton, I957).

\section{Vulpes corsac (L., I768)}

Corsac fox

Distribution. Steppe-lands of southeastern Russia, Volgo-Ural steppes, Russian Turkestan and Kirghizia, to Chinese Turkestan, Mongolia and Transbaikalia. Possibly also Manchuria and Northern Afghanistan (Ellerman \& Morrison-Scott, I966).

Description. A small fox, similar in size to Alopex lagopus, but with relatively longer legs. The fur is thick, soft and pale straw-coloured with darker, slightly tawny markings along the back. Except for a small black patch over the tail gland and a slightly black tip to the tail there is no dark colouring on the head, body or limbs. The underparts are pale. The three specimens in the British Museum (Natural History) have closely similar markings and Ognev (I962) described the same pelage characters. According to Ognev, this fox is less solitary than most species and may hunt in small packs. It feeds on rodents, birds, small reptiles and insects. Like $A$. lagopus the corsac fox may inhabit communal breeding dens.

Skull similar to that of $A$. lagopus but the teeth may be relatively smaller. The temporal ridges are flat and may enclose a lyriform sagittal area.

Systematic position. Percentage similarity to 'near neighbours' :

All characters

Vulpes bengalensis $\quad 93.7$

Vulpes velox 93.3

Dusicyon gymnocercus $90 \cdot 9$

Vulpes ferrilata $\quad 89 \cdot 8$

Dusicyon vetulus
Skull and teeth only

$\begin{array}{ll}\text { Alopex lagopus } & 90 \cdot 8 \\ \text { Vulpes bengalensis } & 90 \cdot 7 \\ \text { Vulpes vulpes } & 90 \cdot 2 \\ \text { Vulpes velox } & 90 \cdot 0 \\ \text { Vulpes chama } & 88 \cdot 8\end{array}$

As shown by the 'near neighbours' tables the corsac fox lies closest to A. lagopus on cranial and dental characters and closest to Vulpes bengalensis on all characters. Phenetically the species is a typical fox, despite its small size and on the twodimensional plots it lies within the Vulpes group. 
Vulpes ferrilata Hodgson, 1842

Tibetan sand fox

Distribution. High plateau country of Tibet and Nepal between 4500 and $4800 \mathrm{~m}$ (Ellerman \& Morrison-Scott, I966 ; Pocock, I94I).

Description. The skins of this apparently rare fox have been described in some detail by Pocock (1936). The body colour is pale grey agouti or sandy with a tawny band along the dorsal region. The fronts of the legs are also tawny; the underparts pale. Insides of the ears white, the outsides similar in colour to the rest of the body. The fur is soft and thick and the tail bushy. The end of the tail is white, whilst the anterior part has a wide band of dark guard hairs. There may be a dark streak over the tail gland. Very little is known of the habits of this fox or of the functions of its extraordinarily long head.

Skull peculiarly elongated and with a very narrow maxillary region. Canine teeth also remarkably elongated and pointed. Cheek teeth well developed but widely spaced in the long jaws. Mandible correspondingly elongated and with relatively little depth. Temporal ridges of the cranium flat and enclosing a narrow, lyriform sagittal area.

Systematic position. Percentage similarity to 'near neighbours' :

$\begin{array}{lr}\text { All characters } & \\ \text { Vulpes corsac } & 89 \cdot 8 \\ \text { Dusicyon gymnocercus } & 89 \cdot 2 \\ \text { Dusicyon culpaeolus } & 89 \cdot 1 \\ \text { Dusicyon australis } & 88 \cdot 9 \\ \text { Vulpes velox } & 87 \cdot 9\end{array}$

Skull and teeth only

$\begin{array}{ll}\text { Vulpes corsac } & 88 \cdot 4 \\ \text { Vulpes velox } & 88 \cdot 0 \\ \text { Dusicyon gymnocercus } & 84 \cdot 9 \\ \text { Vulpes chama } & 84 \cdot 8 \\ \text { Dusicyon microtis } & 82 \cdot 7\end{array}$

Vulpes ferrilata is phenetically closer to the species of Dusicyon than is any other member of the genus Vulpes. Despite the unique appearance of the skull, however, it is of interest that in both near-neighbours tables this fox is slightly closer to Vulpes corsac than it is to any other species. The distribution of $V$. corsac lies to the north of that of $V$. ferrilata and it may be that the Tibetan fox has evolved from the more typical $V$. corsac in response to a specialized environment. An analogous situation may have occurred with Canis simensis which is phenetically close to Canis adustus and has a somewhat similar elongated muzzle.

\section{Vulpes bengalensis (Shaw, I800)}

Bengal fox

Distribution. Open country, thorny scrub or semi-desert areas in southern peninsular India, Travancore, northwards to Sind, Bihar and Orissa, Kangra in Punjab, Haldibari and Nepal up to I350 m (Ellerman \& Morrison-Scott, I966 ; Pocock I94I).

DEscription. This Indian fox is medium-sized and sandy-coloured with soft fur that is not as thick or long as it is in Alopex lagopus or Vulpes corsac. The 
dorsal region of the pelt may be darker or more tawny than the rest which is either pale agouti or fawn, with tawny legs. The insides of the ears are white, the outsides grey, and the underparts are light-coloured or pale ginger. The black tip to the tail is the only dark colouring in the pelage except that in a few specimens there is a small dark patch over the tail gland. Feeds on small animals, including insects, and eggs as well as a fairly high proportion of fruit and berries.

Skull typically 'fox-like', with long sharply pointed canines and well-developed molar teeth. The temporal ridges are flat and may enclose a lyriform sagittal area.

Systematic position. Percentage similarity to 'near neighbours' :

$\begin{array}{ll}\text { All characters } & \\ \text { Vulpes velox } & 94 \cdot 5 \\ \text { Vulpes chama } & 93 \cdot 8 \\ \text { Vulpes corsac } & 93 \cdot 7 \\ \text { Vulpes rueppelli } & 93 \cdot 3 \\ \text { Dusicyon gymnocercus } & 91 \cdot 9\end{array}$

$\begin{array}{ll}\text { Skull and teeth only } & \\ \text { Vulpes chama } & 94 \cdot 9 \\ \text { Vulpes rueppelli } & 92 \cdot 3 \\ \text { Vulpes velox } & 9 \mathrm{I} \cdot 7 \\ \text { Vulpes pallida } & 9 \mathrm{I} \cdot 4 \\ \text { Vulpes vulpes } & 9 \mathrm{I} \cdot 4\end{array}$

The Bengal fox has a similarity of over 90 with other species of fox shown in the table above and as can be seen from Table 2, it is the 'most typical' member of the genus for the 'all-character' results and is only three below Vulpes chama for the skull characters. It is reasonable therefore to assume that Vulpes bengalensis typifies the 'basic fox'.

\section{Vulpes cana Blanford, 1877}

Blanford's fox

Distribution. Not well known but probably the mountain areas of Kopet Dag, southwestern Russian Turkestan, Afghanistan, northeastern Iran and Baluchistan (Ellerman \& Morrison-Scott, I966; Ognev, I962).

DESCRIPTION. A small fox with extremely soft fur and a long very bushy tail. The colouring is a blotchy black, grey and white with a dark tip to the tail and a dark patch over the tail gland. There is an almost black mid-dorsal line and the hind legs may be dark. Blanford (I888) described the pelt as having a 'rufescent tinge' but the skins examined in the British Museum appear to have no red pigment in the hair (see Table 6). The underparts are almost white ; the ears are grey, and there is a small dark patch between the eyes and nose.

The condylo-basal length of the skull exceeds that of Vulpes zerda (the smallest species of canid) by only a few millimetres. Despite its small size the skull and dentition are typically vulpine with small sharply pointed teeth, flat temporal ridges and a narrow maxillary region.

Systematic position. Percentage similarity to 'near neighbours' :

All characters

Vulpes rueppelli
Vulpes bengalensis
Vulpes velox
Vulpes zerda
Vulpes chama

$85 \cdot 5$

$84 \cdot 6$

$84 \cdot 3$

$83 \cdot 4$

$83 \cdot 0$
Skull and teeth only

$\begin{array}{ll}\text { Vulpes zerda } & 89 \cdot 5 \\ \text { Vulpes velox } & 88 \cdot 1 \\ \text { Vulpes chama } & 87 \cdot 6 \\ \text { Vulpes rueppelli } & 87 \cdot 0 \\ \text { Vulpes pallida } & 87 \cdot 0\end{array}$


The numerical results show a rather low similarity for this species with the rest of the genus Vulpes. On the two-dimensional plots, however, Vulpes cana lies close to the sand foxes and its phenetic relationships must be with this group.

\section{Vulpes rueppelli (Schinz, I825)}

\section{Sand fox}

Distribution. Arid areas of North Africa, southern Arabia, Persian Baluchistan and Afghanistan (Ellerman \& Morrison-Scott, I966; Harrison, I968).

Description. A large-eared, desert, sand fox. The pelage is reddish-grey agouti with dark guard hairs on the tail and a dark patch between the eyes and nose. Light underparts. Ears not distinct in colour from the rest of the body. As with the other desert foxes, Vulpes pallida and Vulpes zerda, the facial vibrissae are particularly long and black.

Skull small but typically vulpine with a straight profile, narrow maxillae and small sharp canine teeth. Bullae large but not so expanded as in V. zerda.

Systematic position. Percentage similarity to 'near neighbours' :

$\begin{array}{ll}\text { All characters } & \\ \text { Vulpes bengalensis } & 93 \cdot 3 \\ \text { Vulpes chama } & 9 \mathrm{I} \cdot \mathbf{I} \\ \text { Vulpes velox } & 9 \mathrm{I} \cdot \mathbf{I} \\ \text { Dusicyon culpaeolus } & 88 \cdot 9 \\ \text { Vulpes corsac } & 88 \cdot 7\end{array}$

$\begin{array}{lr}\text { Skull and teeth only } & \\ \text { Vulpes bengalensis } & 92 \cdot 3 \\ \text { Vulpes chama } & 90 \cdot 9 \\ \text { Vulpes velox } & 89 \cdot 8 \\ \text { Vulpes pallida } & 89 \cdot 6 \\ \text { Dusicyon gymnocercus } & 87 \cdot 1\end{array}$

Vulpes rueppelli is a small fox that is well adapted to life in dry sandy environments but it does not have the extreme desert-characters that are seen in $V$. zerda. The 'near-neighbours' tables and two-dimensional plots show that the species is phenetically close to Vulpes bengalensis and to the desert foxes (described in the following sections).

\section{Vulpes pallida (Cretzschmar, I826)}

Pale fox

Distribution. Dry sandy areas in a line running across Africa from Senegal through Nigeria and Cameroun to the Sudan and Somalia (Allen, I939; Ellerman \& Morrison-Scott, I966).

Description. A small ginger-coloured fox with large ears that are the same colour as the body. The tail is dark and has a black tip and a dark patch over the tail gland. The underparts are pale and may be a pinkish ginger. Legs rufous. No dark patch between the eyes and nose.

Skull small with a wide lyriform sagittal area and a relatively short maxillary region. The upper molars are well developed in relation to the carnassial teeth $\left(\mathrm{P}^{4}\right)$ which are weak. 
Systematic position. Percentage similarity to 'near neighbours' :

All characters

Vulpes chama

Dusicyon sechurae

Dusicyon fulvipes

Vulpes bengalensis

Dusicyon gymnocercus

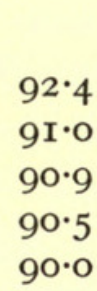

$92 \cdot 4$

$9 \mathrm{I} \cdot \mathrm{O}$

$90 \cdot 9$

$90 \cdot 5$

$90 \cdot 0$
Skull and teeth only

$\begin{array}{lr}\text { Vulpes chama } & 95 \cdot 2 \\ \text { Vulpes bengalensis } & 9 \mathrm{I} \cdot 4 \\ \text { Vulpes rueppelli } & 89 \cdot 6 \\ \text { Vulpes velox } & 89 \cdot 0 \\ \text { Vulpes cana } & 87 \cdot 0\end{array}$

The systematic position of Vulpes pallida was discussed by Thomas (I9I8) in a short note on the sand foxes of North Africa. Thomas associated $V$. pallida with Vulpes rueppelli and Vulpes zerda and this grouping has been generally followed since then. Our numerical analysis of the phenetic characters suggests that these desert foxes are more closely related to the Indian fox Vulpes bengalensis and to the South African Vulpes chama than had been previously realized. The situation can be seen best as a series of species ranging in an arc from $V$. chama through $V$. pallida, $V$. zerda and $V$. rueppelli to $V$. bengalensis, with $V$.zerda as the most highly specialized desert form.

Vulpes cana (Blanford's fox) falls geographically within this arc, but it is adapted to a montane rather than a desert environment and its unusual pelage characters set it apart from the rest of the series.

\section{Vulpes zerda (Zimmermann, I780)}

Fennec fox

Distribution. Desert areas of Morocco, Algeria, Libya, Egypt and east to Sinai and Arabia. Also south to the Sudan (Ellerman \& Morrison-Scott, I966 ; Harrison, I968).

DESCRIPTION. The smallest species of canid, with extraordinarily large ears. The pelage has no agouti hairs but is an evenly pale fawn colour with almost white underparts. The tail tip is dark and there is a dark patch over the tail gland; these being the only parts of the body that are not pale in colour. There may be a ginger line along the back. The facial vibrissae are very long.

Skull very small with exceedingly large swollen bullae. Otherwise typically vulpine, except that the cranium is rather rounded and the dentition is weak. The sagittal area, enclosed by barely perceptible temporal ridges, is very wide.

Systematic position. Percentage similarity to 'near neighbours' :

All characters

Vulpes chama

Vulpes pallida

Vulpes bengalensis

Dusicyon fulvipes

Vulpes velox
Skull and teeth only

$\begin{array}{lr}\text { Vulpes cana } & 89 \cdot 5 \\ \text { Vulpes pallida } & 86 \cdot 9 \\ \text { Vulpes bengalensis } & 85.9 \\ \text { Vulpes chama } & 85.2 \\ \text { Vulpes rueppelli } & 83.7\end{array}$


$V$. zerda has been traditionally placed in a separate genus, Fennecus, and this classification is generally followed on account of this fox's huge ears, pale colouring and rounded skull. These characters should be seen, however, in their true context as adaptations to a most specialized environment. Like Alopex lagopus the fennec lies on the periphery of the fox group because it is adapted to extreme conditions where the biotic abundance is very low.

Table 3 shows that the fennec fox lies above Vulpes ferrilata, Vulpes vilpes and $V$ ulpes cana in order of typicality and in the 'near neighbours' table it is seen to have similarity values of nearly 90 with the other small species of fox. The two-dimensional plots and centroid linkage dendrograms also show that the fennec lies well within the genus, more so than $V$. vulpes. It would therefore be irrational for us to exclude this species and although it makes for nomenclatural difficulties (see p. I50) we are constrained to transfer it to the genus Vulpes.

\section{Vulpes chama (A. Smith, I833)}

Cape fox

Distribution. Dry areas of southwestern Africa, Transvaal and possibly western Rhodesia. Probably extinct in the Capetown area (Allen, I939; Ellerman et al., I953).

Description. A relatively large fox, similar in size to Vulpes bengalensis. The fur is soft and short and the colouring of the body is rufous agouti. There may be long black guard hairs on the bushy tail and on the posterior dorsal region. The tail has a distinct black tip and there is a diffuse dark patch over the tail gland. The underparts are a pale rufous with a lighter chin. The legs are more tawny than the general body colour. There is no dark mark between the eyes and nose.

Skull very similar to that of $V$. bengalensis, but the cranium is slightly wider and the maxillary region slightly shorter (see Table 4).

Systematic position. Percentage similarity to 'near neighbours' :

All characters

Vulpes bengalensis

Vulpes pallida

Dusicyon culpaeolus

Vulpes velox

Dusicyon gymnocercus
$93 \cdot 8$

$92 \cdot 4$

$92 \cdot 2$

$92 \cdot 0$

$9 \mathrm{I} \cdot 3$
Skull and teeth only

Vulpes bengalensis $\quad 95^{\circ} 2$

Vulpes pallida $\quad 94.9$

Vulpes velox $\quad 92 \cdot 6$

Vulpes rueppelli $\quad 90 \cdot 9$

Dusicyon sechurae $\quad 89 \cdot 8$

The numerical results show that Vulpes chama is surprisingly closely related in its phenetic characters to the Bengal fox, $V$. bengalensis, and to the more northerly African fox, Vulpes pallida. On skull characters $V$. chama heads the list as the most typical member of the genus (Tables 2,3) and as described under the description of $V$. pallida, it seems clear that this South African fox should be considered as one end of an arc of related species that have evolved in response to varying degrees of desert conditions. 


\section{Vulpes velox (Say, I823)}

Kit fox

For the purposes of this analysis Vulpes macrotis Merriam, I 888 was included within the species Vulpes velox.

Distribution. Prairies of western North America. Distribution not well known but certainly decreasing. The northern subspecies is classed as endangered by the Red data book (Goodwin \& Holloway, I972); it is extinct in Canada.

Description. A medium-sized fox with very thick soft underfur and long agouti guard hairs. The body colouring may be tawny or light ochreous and grey. Tail relatively short and very bushy with a black tip and a slight black patch over the tail gland. There is a dark patch between the eyes and the nose. Large ears white inside and grey or ochreous outside. Almost white underparts. Limbs tawny.

Skull typically 'fox-like' and very similar to that of Vulpes chama and Vulpes bengalensis. Upper molar teeth slightly less well developed than in the latter species. Temporal ridges flat and enclosing a narrow lyriform sagittal area.

Systematic Position. Percentage similarity to 'near neighbours' :

$\begin{array}{ll}\text { All characters } & \\ \text { Vulpes bengalensis } & 94 \cdot 5 \\ \text { Vulpes corsac } & 93 \cdot 3 \\ \text { Vulpes chama } & 92 \cdot 0 \\ \text { Vulpes rueppelli } & 9 \mathrm{I} \cdot \mathrm{I} \\ \text { Dusicyon culpaeolus } & 90 \cdot 5\end{array}$

Skull and teeth only

$\begin{array}{ll}\text { Vulpes chama } & 92 \cdot 6 \\ \text { Vulpes vulpes } & 9 \mathrm{I} \cdot 8 \\ \text { Vulpes bengalensis } & 9 \mathrm{I} \cdot 7 \\ \text { Vulpes corsac } & 90 \cdot 0 \\ \text { Vulpes rueppelli } & 89 \cdot 8\end{array}$

It is clear from the results of this analysis that the phenetic affinities of $V$. velox lie with the 'most typical' members of the genus, these being $V$. bengalensis from India and $V$. chama from South Africa. On the other hand, the similarity of $9 \mathrm{I} \cdot 8$ that the skull of $V$. velox bears to that of $V$. vulpes may provide a link between this widespread but somewhat discrepant species and the more typical group. Support for this may be seen in the work done by Creel et al. (I97I, I974) on hybridization between the kit fox and the common fox.

\section{Vulpes cinereoargenteus (Schreber, I775)}

Grey fox

Distribution. Widespread in wooded country and along river valleys throughout Central and North America and the northern part of South America but not in the high plains (Cabrera, I958; Hall \& Kelson, I959; Miller \& Kellogg, I955). A versatile carnivore that will easily adapt from a wooded to a pastoral environment (Hershkovitz, I972:372).

Description. A medium-sized, typically 'fox-like' canid. Body colour grey agouti with white jaws and throat. Ears and sides of neck ochreous or tawny. 
Chin grey or brown; underparts pale; legs and feet tawny. Long bushy tail. A dorsal black stripe extends from the mid-line of the back along the whole of the tail to the tip which is black. Hildebrand (1952b) stated that the tail gland is longer in this species than in any other canid. The gland is covered by a ridge of stiff guard hairs. (This character was used by Gray (I868) to support his classification of the grey fox in the separate genus Urocyon Baird, 1857.) Feeds on the usual small animals and birds that all foxes prey upon. The grey fox is said readily to climb trees to escape from hunters or other enemies - a most unusual habit for a canid.

Teeth well developed. Canines not as long as is typical for the fox group as a whole, and the premolars high-crowned in relation to their length. Carnassial and molar teeth 'fox-like'. The cranium is distinctive and similar to that of Otocyon megalotis in having the temporal ridges well developed but separated by a wide sagittal area. The surface of the parietal bones is rugose, whilst that of the sagittal area is smooth. The frontal sinuses are present only as barely visible pockets (in a bisected skull) below the postorbital processes. There is a subangular lobe on the mandible but it is not so well developed as in $O$. megalotis.

Systematic position. Percentage similarity to 'near neighbours' :

All characters

Vulpes bengalensis

Vulpes velox

Vulpes corsac

Vulpes rueppelli

Vulpes pallida

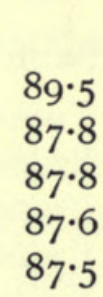

$89 \cdot 5$

$87 \cdot 8$

$87 \cdot 8$

$87 \cdot 6$

$87 \cdot 5$
Skull and teeth only

$\begin{array}{lr}\text { Vulpes pallida } & 85.5 \\ \text { Vulpes chama } & 85.1 \\ \text { Vulpes rueppelli } & 84.9 \\ \text { Vulpes velox } & 83.5 \\ \text { Vulpes bengalensis } & 83.3\end{array}$

A second species of grey fox, usually described as Urocyon littoralis Baird, I858, is an island form that is probably closely linked to the mainland species. It has not been included in this analysis.

The systematic position of the grey fox has been one of the most interesting problems to emerge from the present analysis. There has been little work done on the affinities of the species in the past although both Huxley (I880) and Guilday (I962) have observed the similarity in skull conformation between the grey fox and O. megalotis.

The separation of the grey fox in the genus Urocyon is generally accepted, and it has been asserted since the time of Mivart (I890) that this fox has more in common with the South American canids (genus Dusicyon) than with the common fox (Vulpes vulpes), the only member of the fox group with which it has been compared by mammalogists. The misconception has arisen, in part, because of the atypical appearance of the common fox in comparison with the rest of the genus, and it may also stem from the work of Osgood (I934) who described the grey fox in his paper on the South American canids and, by implication, clearly thought of it as belonging to the South American group. He made no mention of any possible relationship of the species with Vulpes, and inferred that Vulpes cinereoargenteus was more closely related to Dusicyon than was Chrysocyon brachyurus, the maned wolf, a theory for which this analysis gives no support at all. It can, in fact, be asserted 
that the grey fox bears less phenetic resemblance to the South American genera of canids than do most other members of the family, and it can be shown, for the first time, that there is a considerable similarity (almost 90 per cent for all characters) between the grey fox and the typical Vulpes bengalensis. Furthermore $V$. cinereoargenteus has no similarity with any genus other than Vulpes in the 'near neighbours' tables.

The development of the temporal ridges and subangular lobe of the mandible do place the skull apart from all other members of Vulpes but within the terms of this numerical taxonomy it would not be consistent to keep the grey fox as a separate genus. It lies on the periphery of the Vulpes group, as can be seen from the twodimensional plots, but less so than $V$. vulpes or $V$. ferrilata.

The southerly distribution of $V$. cinereoargenteus in relation to its phylogenetic origin has been much discussed. Most authors (including Mivart, I890) have agreed that it must be a latecomer to South America. Hershkovitz (I972:3I2) described the species as a 'varicant', straddling the Nearctic and Neotropical regions and not clearly derived from either. He postulated further (p. 359) that the grey fox may have originated in Middle America and spread during the Quaternary into Canada and South America.

Now that the species has been critically examined in relation to all the other members of the canid family it may be said that derivation from Dusicyon or an autochthonous origin in Middle America seems unlikely. It appears that it has closer phenetic links in the Asiatic species of Vulpes than was previously suspected and perhaps it has been pushed south as a result of competition with the other canid species in North America, and in particular the highly successful $V$. vulpes which was probably aided in the extension of its range by the activities of man (see p. I53).

\section{Genus ALOPEX Kaup, I829}

One species.

\section{Alopex lagopus (L., I758) \\ Arctic fox}

Distribution. Arctic tundra of Europe, Asia and North America and areas of montane tundra in Scandinavia. In Asia southwards to Kamchatka (Ellerman \& Morrison-Scott, I966; Macpherson, I969).

Description. A small compact fox. The pelage is distinct in that it has two colour phases. One phase is pure white in winter, whilst in summer the back, legs, tail and head are dark brown and the underparts are light. The other phase is described as 'blue' and is more variable, being grey, brown or black in summer and winter. The fur is thick and very soft with guard hairs as fine and long as the underfur. Muzzle and ears relatively short, tail very thick and bushy. The Arctic fox is solitary in its hunting habits but the breeding dens are often found in colonies. 
Skull rather shorter in the palatine region than in Vulpes vulpes and the frontal bones are slightly swollen at their junction with the nasals, but this does not affect the depressions on the postorbital processes which are characteristic of the genus Vulpes. Dentition as in $V$. vulpes but the canines may be relatively shorter.

The Arctic fox feeds on small mammals, especially lemmings (Dicrostonyx and Lemmus spp.) and carrion. When lemmings are scarce the fox will feed more heavily on birds' eggs, insects, berries and other fruits and seeds.

Systematic position. Percentage similarity to 'near neighbours' :

All characters

Vulpes pallida

Vulpes chama

Vulpes corsac

Dusicyon gymnocercus

Dusicyon culpaeolus
$8 \mathbf{r} \cdot 6$

$8 \mathrm{I} \cdot 5$

$8 \mathrm{I} \cdot 2$

$8 \mathrm{I} \cdot \mathrm{O}$

$80 \cdot 7$
Skull and teeth only

$\begin{array}{ll}\text { Vulpes corsac } & 90 \cdot 8 \\ \text { Vulpes vulpes } & 89 \cdot 6 \\ \text { Vulpes rueppelli } & 86 \cdot 7 \\ \text { Vulpes bengalensis } & 86 \cdot 3 \\ \text { Dusicyon culpaeolus } & 85 \cdot 2\end{array}$

Up to the present time the Arctic fox has been commonly classified in a separate genus, Alopex Kaup, I829, although some authors, including Bobrinskii (I965), have preferred to make Alopex a subgenus of Vulpes. Miller (I9I2, p. 3I8) listed the following distinctive characters in support of separate generic status: 'Skull intermediate in general form between that of Canis and Vulpes; occipital depth about one third condylo-basal length; interorbital region more elevated than in Vulpes; postorbital processes thin, flat, or slightly concave above, with bead-like overhanging edges ; dorsal profile of forehead rising abruptly above rostrum as in Canis ; teeth moderately heavy and large ; external form fox-like, but ear short and rounded, not conspicuously overtopping the surrounding fur.' Miller went on to state that although in most respects intermediate between Canis and Vulpes the Arctic foxes form such a natural group that they should be in a distinct genus.

When the skull of the Arctic fox is compared with that of Vulpes vulpes most of the above distinctions can be seen to hold, although we have not noticed any difference in the degree of depression in the postorbital processes in Alopex lagopus. When the skull is compared with that of Vulpes corsac, however, there are fewer differences and as can be seen from the 'near neighbours' table, A. lagopus has a similarity of 90 with the skull of this species.

Alopex lagopus is a species of fox that has special adaptations to life in an arctic environment where there is low biotic abundance, and although the skull is similar to that of $V$. corsac, on the numerical results for all characters the species is separated at a similarity of only just over 8o. It is clear from the two-dimensional plots that the Arctic fox lies close to the genus Vulpes but its inclusion amongst the foxes in the table of 'typicality' (Table 3) shows that it is the most aberrant of the foxes and there are therefore grounds for retaining it in a separate genus.

Genus OTOCYON Muller, I836

One species. 


\section{Otocyon megalotis (Desmarest, I822)}

Bat-eared fox

Distribution. Arid areas in South Africa, southern Angola, Botswana, perhaps western Rhodesia, East Africa and northwards to the Sudan, Ethiopia and Somalia (Ellerman et al., I953).

Description. A long-legged, medium-sized fox with very large, wide ears, long fur and a very bushy tail. The general colour is brownish or ochreous with grey agouti guard hairs. Throat, underparts and insides of ears pale. Limbs nearly black as are the outsides of the ears and the muzzle. Black tip to the tail. Omnivorous, social animals, living in groups and feeding on insects, small rodents, fruit and berries. Adapted to life in a desert environment.

Apart from the dentition the skull bears a singular resemblance to that of Vulpes cinereoargenteus, with well-developed temporal ridges enclosing a wide sagittal area and rugose parietal bones that contrast with the smooth surface of the sagittal area. Bullae large. No frontal sinuses. Dentition unique in that there are always at least three upper and four lower molar teeth. Carnassials much reduced in length. Canines large and 'fox-like'. Premolar teeth high-crowned in relation to their length as in $V$. cinereoargenteus. Subangular lobe of the mandible unusually large. Basal line of the horizontal ramus very straight.

Systematic position. Percentage similarity to 'near neighbours' :

$\begin{array}{lr}\text { All characters } & \\ \text { Vulpes chama } & 75 \cdot 6 \\ \text { Vulpes vulpes } & 73 \cdot 4 \\ \text { Vulpes pallida } & 72 \cdot 7 \\ \text { Vulpes cinereoargenteus } & 72 \cdot 6 \\ \text { Vulpes velox } & 72 \cdot 0\end{array}$

Skull and teeth only

Vulpes cinereoargenteus $75 \cdot 9$

Vulpes pallida $67 \cdot \mathbf{I}$

Nyctereutes procyonoides $66 \cdot 0$

Vulpes rueppelli $\quad 65 \cdot 6$

Vulpes vulpes $65 \cdot 6$

Huxley (I880) suggested that Otocyon megalotis was the most primitive member of the canid family and that its extra molar teeth represented the basic mammalian dentition. Matthew (I930: I23) believed that 'an extra upper and lower molar had appeared', but he gave no further explanation of this appearance. Guilday (I962) put forward the theory that the extra teeth were the result of a mutation that duplicated the upper first and lower second molars at the expense of the carnassial teeth which were correspondingly shortened in length. This theory seems sound, for the molars in question are most similar to each other. That this mutation is of considerable age is shown by the finding of a primitive Otocyon in the Villafranchian of Olduvai, Tanzania. This specimen was named Protocyon reckii by Petter (I964) who considered it to be more primitive than the Recent form and ancestral to it. Simpson (I945: 224) tentatively allowed the subfamily rank of Otocyoninae Trouessart, I885 to stand for this monotypic genus but it is clear that he did not really approve of it. Our numerical results support Simpson's hesitation and there seems little doubt that $O$. megalotis should be considered as an aberrant fox with affinities to Vulpes cinereoargenteus. There is therefore no justification for the recognition of a 
subfamily Otocyoninae, but the generic status of Otocyon is clearly established by the low level of similarity that it bears to all other species. The similarities in behaviour between $O$. megalotis and Nyctereutes procyonoides are discussed in the next section.

\section{Genus NYCTEREUTES Temminck, I839}

One species.

\section{Nyctereutes procyonoides (Gray, I834)}

\section{Raccoon dog}

Distribution. River valleys and the edges of forests in the Amur and Ussuri region of eastern Siberia, Japan, Manchuria, China and Indo-China (Ellerman \& Morrison-Scott, I966; Ognev, I962). Introduced and now widespread in European Russia and eastern Europe.

DESCRIPTION. A rather slow-moving, heavy-bodied canid with a small head and short limbs. The pelage characters give it a superficial resemblance to the raccoon, Procyon lotor (L.). The back is a mottled tawny and black, the guard hairs being long, banded, rather coarse and shiny; the underfur is abundant, soft and fawn in colour. The tail is rather short and dark at the end but without a distinct black tip. Limbs fawn or dark brown. The facial region is short. The raccoon dog is the only species of canid that has a distinct dark mask around the eyes and between the eyes and ears. Beneath each eye there is a diffuse white band stretching back to the ears and emphasizing the dark mask. Underparts brown, beige or fawn. Nocturnal, fossorial, hunting in pairs or family groups. Preferred habitat, small forested areas near water, and river valleys. Diet very varied : often eats fish and feeds on small rodents, amphibians, eggs, shellfish, berries and acorns (Ognev, I962). Hibernates.

Skull small with short nasals and maxillary region. Distinct subangular lobe to the mandible but not so highly developed as in Otocyon megalotis. Teeth small and weakly developed. Molars somewhat bunodont. Palatine bones extend backwards beyond $\mathrm{M}^{2}$. Surface of parietal bones rugose. Temporal ridges fused to form a slight interparietal crest. Orbits relatively small. Frontal sinuses moderately large.

Systematic position. Percentage similarity to 'near neighbours' :

All characters

Dusicyon microtis

Dusicyon australis

Dusicyon thous

Dusicyon vetulus

Dusicyon sechurae
$78 \cdot 1$

$77 \cdot 4$

$76 \cdot 8$

$76 \cdot 4$

$75 \cdot 7$
Skull and teeth only

Dusicyon sechurae $\quad 86 \cdot 2$

Canis aureus $\quad 83.5$

Dusicyon australis $\quad 83.2$

Alopex lagopus $\quad 82.9$

Vulpes cinereoargenteus $82 \cdot 2$ 
It is difficult to assess the systematic position of Nycterentes procyonoides as it has no close affinities with any of the other canids. The 'near neighbours' tables place the genus at a low level of similarity with the Dusicyon group and in this context it may be mentioned that in I880 Huxley wrote, in his study of the Canidae: 'Nyctereutes is essentially a low Thooid of the South American type.'

Radinsky (I973) has suggested on the basis of the shape of the prorean gyrus of the brain that the raccoon dog should be linked with the foxes. The presence of fairly well-developed frontal sinuses in the skull does not, however, lend support to this view. Kleiman ( 1967$)$ in her study of some aspects of the behaviour of the Canidae asserted that Nycterentes is unique in that a submissive animal does not wag its tail. She noted several striking similarities between the raccoon dog and the bat-eared fox $(O$. megalotis). Both engage in communal sleeping and social grooming which she says may be related to the black facial mask that is present in both species although much more extensive in Nycterentes where, as previously stated, it surrounds the eyes and goes back to the ears. Both species share a peculiar tail posture; in dominant animals or in a sexually aroused male the tail is carried in an inverted $\mathrm{U}$-shape, and the black hair on the tail is erected and stands up prominently.

There can be little doubt about the generic status of Nycterentes. On the twodimensional plots and on the centroid linkage dendrograms the raccoon dog is always an outsider and it bears a similarity value of less than 75 with the genera Canis, Vulpes and Dusicyon (Table I).

\section{Genus DUSICYON Hamilton Smith, I839}

Type species Dusicyon australis (Kerr, I792)

All the species within the genus Dusicyon are restricted to the continent of South America and its neighbouring southern islands. The number of taxa that we suggest should be included in the genus differs from that of the accepted check list of Cabrera (1958) which excludes Dusicyon thous and Dusicyon microtis. Of the eleven species that were examined for this analysis eight form a phenetically closely linked group and it is suggested that further work at the specific level might lead to the elimination of four of these. Three species, D. australis, D. thous, and D. microtis lie on the periphery of the group and their taxonomic position is discussed.

It is difficult to give a diagnosis for the genus as in many characters it lies between Canis and Vulpes, with $D$. australis presenting the most 'dog-like' features and $D$. vetulus the most 'fox-like'. An indication of this intermediate state is apparent in the descriptions of the early authors who wrote of the animals as 'foxes', 'wild dogs' or 'wolves'. Gray (I868) described them as 'fox-tailed wolves'.

The pelage is usually grey agouti with some ochreous or tawny colouring, with the exception of $D$. microtis which is dark all over. The ears are fairly large and erect ; the head is rather narrow, and the tail is very long, bushy and has a contrasting dark tip (white in $D$. australis). The underparts are usually pale and the legs ochreous or tan. The skull is rather long and narrow with temporal ridges either apart and enclosing a lyriform sagittal area or nearly fused. There is no well-marked interparietal crest. Dentition is more 'fox-like' than 'dog-like'. The canines are long 
and finely pointed; the premolars and carnassials are high-crowned, and the molars are well developed. The carnassial teeth are short relative to the lengths of the molars and to the condylo-basal length. The palatine bones may extend backwards beyond $\mathrm{M}^{2}$.

Early writers on this group of South American canids usually placed them all within the genus Canis until the work of Thomas (I9I4) which brought the following generic names into common use: Dusicyon Hamilton Smith, I839; Cerdocyon Hamilton Smith, I839; Pseudalopex Burmeister, I856 ; Lycalopex Burmeister, I856.

Thomas designated the Falkland Island 'dog' (formerly known as Canis antarcticus Shaw, I80o) as the type of Dusicyon.

With the general acceptance of Pocock's paper (I9I3) on the affinities of the Falkland Island 'wolf', in which he allied this species closely with the other South American canids, Thomas's classification was followed, with minor alterations, by Kraglievich (I930) and Cabrera (I93I). Osgood (I934) reduced Cerdocyon, Psendalopex and Lycalopex to subgenera of Dusicyon and retained D. australis as D. (Dusicyon) australis. Simpson (I945) accepted this classification, but most recent authors have followed Cabrera's further modifications, in which he placed D. thous in the genus Cerdocyon and separated D. microtis into a new genus Atelocynus Cabrera, I940, leaving the remainder as Dusicyon. Langguth (I970, I975) went further and separated Lycalopex vetulus as an additional monospecific genus, while including the remaining species of Dusicyon in Canis.

The subgenus has been avoided throughout this work because of the absence of sufficiently discrete groups at the appropriate level. This being so, and after a careful examination of the numerical results, it has been decided to include all the genera and subgenera mentioned above within the genus Dusicyon.

\section{Dusicyon australis (Kerr, I792)}

Falkland Island wolf

Although well known from the descriptions of Darwin and others, no detailed examination has been made of the available material of this extinct species since the account of Pocock (I9I3). It was therefore considered appropriate to give here a fresh description of the material that is held in the British Museum (Natural History) especially as there are many interesting features about the skulls and skins that make the systematic position of the species hard to define.

MAterial. No. 37-3.I5.47. The holotype of Dusicyon darwini Thomas, I9I4. Skull, mandible and skin from East Falkland Island. Collected by Charles Darwin and presented by Burnett and Fitz Roy. There are shot holes in the frontal bones behind the orbits and the occipital region of the skull is missing. Young adult male. Data on this specimen were used in the analysis.

No. 37.3.I5.48. Skull, mandible and skin from West Falkland Island. Collected by Charles Darwin and presented by Burnett and Fitz Roy. Skull complete except for the left zygomatic arch which is missing. Young adult female. Data used in the analysis. 
No. 69.2.24.3 (I692a). Skull without mandible; complete except for the right canine tooth which is missing. No history except that the skull was purchased from E. Gerrard, jun. It is, however, likely that this skull came from the live animal that was brought to the Zoological Gardens, London, by Mr A. A. Lecombe in I868 (Newton, I868). Young adult. This skull was not available at the time the numerical analysis was carried out but it agrees in every important respect with those specimens that were used.

No. 85.I0.I2.I (I962b). Skull without mandible. North coast, West Falkland Island. Dentition and zygomatic arches incomplete. Presented by E. A. Holmsted. The skull had obviously lain in the sea for some time as it is covered with tiny barnacles. This could raise the possibility that it actually came from a domestic dog rather than from Dusicyon australis. The skull, however, has all the characters that are typical of the Falkland Island 'wolf' rather than of a domestic dog; these being the raised sagittal area and lack of interparietal crest, the extension of the palatine bones backwards from $\mathrm{M}^{2}$, and the development of the malar bone (see Pocock, I9I3). Data on this skull were included in the analysis.

No. I974.483 (I692b). Left mandibular ramus with $\mathrm{P}_{2}, \mathrm{P}_{3}, \mathrm{P}_{4}, \mathrm{M}_{1}$. Although this mandible has the same number as the old registered number of the skull above (no. 85.I0.I2.I) it cannot be from the same animal as it is too large; nor does it fit the other skull with no mandible (no. 69.2.24.3). There is no history for this specimen and it is not recorded in the British Museum catalogues. It can be identified as $D$. australis on the unique character of the lower carnassial in which the little cusp (metaconid) at the base of the main cusp, on the lingual side of the tooth, lies only slightly above the inner cusp of the talonid. Data from this mandible have not been used in the analysis.

A further two skulls from the collection of the Royal College of Surgeons (nos 635 \& 636) were described by Pocock (I9I3) and Thomas (I9I4) but unfortunately these have been missing since the I939-45 war. These two skulls were catalogued as follows by Flower (1884) : No. 635. Skull O.C. 4363. Presented by Admiral Sir Francis Beaufort. No. 636. Skull. Found by the donor on West Falkland Island. Presented by E. A. Holmsted, Esq., I878.

Distribution. Inhabited East and West Falkland Islands until about I880 when the species became extinct.

Description. A 'large wolf-like fox' (Darwin, I860) with a short face, wide muzzle and short ears. The tail short with a white tip. Coat thick and soft, mainly brown in colour with some rufous and speckled with white from pale guard hairs. Underparts pale, becoming cream at the posterior ventral surface. As remarked by Mivart (I890) and Pocock (I9I3) there is a dark reddish patch above the hock of the hind leg. The middle part of the tail has long dark guard hairs that contrast with the white tip. They fed mainly on birds, especially the upland goose, Chloephaga picta.

Skull large, with relatively wide palatine region. Temporal ridges well developed, enclosing a lyriform sagittal area which is flattened and only formed into an interparietal crest at the posterior end of the cranium. Enlarged frontal sinuses. No 
subangular lobe to the mandible. Palatine bones extend backwards beyond the posterior edge of $\mathrm{M}^{2}$. Teeth large and somewhat compacted in the premolar region. Canines 'fox-like', premolars simple and high-crowned. $\mathrm{P}^{4}$ with the protocone drawn backwards and reduced. Inner tubercle (metaconid) of $M_{1}$ placed very low, on a level with the posterior cusps (talonid), as figured by Pocock (I9I3:390).

The animals that inhabited the East Falkland Island were said to be larger and less red than those on the West Island. Hamilton Smith (I839) recorded a legend that the eastern group was descended from dogs left on the island by the Spanish, whereas the western group consisted of truly wild indigenous 'foxes'. Thomas (IgI4) examined the material in the British Museum and in the Royal College of Surgeons and decided that two species were represented. These he named Dusicyon darwini (eastern) and Dusicyon antarcticus (western).

Apart from there being some doubt about which island two of the skulls originated from, with Thomas altering 'west' to 'east' to suit his case, an examination of the four skulls and two skins now available shows a remarkable similarity between them. Aside from the variation in size that could be due to sex there are few differences in the skull that could be even ascribed to individuality. When Darwin visited the Falkland Islands in I834 it was apparent to him that the wild 'foxes' that he saw there were doomed to extinction (Darwin \& Waterhouse, I840) and fifty years later they had indeed been exterminated. There remain, however, several contemporary accounts of the species, as well as the few specimens preserved in museums. The extinction of this species was due to indiscriminate slaughter and to the value of its fur to traders as far away as New York. The generic name of Dusicyon was given to this species by Hamilton Smith in I839 after he had seen a large collection of pelts in a fur store in New York, owned by a Mr Astor. Hamilton Smith described these pelts as indistinguishable from those of Lyciscus cagottis (the Mexican coyote, Canis latrans).

Systematic position. Percentage similarity to 'near neighbours' :

All characters

Vulpes ferrilata

Canis aureus

Dusicyon sechurae

Dusicyon culpaeolus

Dusicyon gymnocercus
$88 \cdot 9$

$88 \cdot 8$

$88 \cdot 6$

$88 \cdot 6$

$87 \cdot 7$
Skull and teeth only

$\begin{array}{ll}\text { Canis mesomelas } & 92 \cdot 5 \\ \text { Canis aureus } & 9 \mathrm{I} \cdot 4 \\ \text { Dingo } & 9 \mathrm{I} \cdot \mathrm{I} \\ \text { Canis latrans } & 88 \cdot 9 \\ \text { Dusicyon sechurae } & 88 \cdot 6\end{array}$

Pocock (I9I3) examined the skulls and skins of $D$. australis and decided that they bore a close affinity with Dusicyon culpaeus and that the species could be in no way a near relation of Canis latrans. Pocock was incited to pay attention to the Falkland Island 'wolf' by a quotation of Lydekker's from Huxley's work on the cranial and dental characters of the Canidae (I880). In this work Huxley concluded that $D$. australis was in some skull characters close to $C$. latrans.

The results of the present analysis support Huxley's observations in showing that the skull and teeth are closer to Canis than to Dusicyon. There are definite characters, however, like the length and shape of the canines that more closely resemble 
Dusicyon, and the shape of the lower carnassial tooth is unique. So it will not be proposed here that the Falkland Island 'wolf' be returned to the genus Canis; the results are too uncertain and there is not enough material to make a thorough investigation possible. It may be remarked, however, that Pocock was somewhat hasty in his total rejection of Huxley's observations which in this, as in other parts of the work, are found to agree very well with the results obtained from our numerical analysis. In the two-dimensional plots as well as in the dendrogram for cranial and dental characters $D$. australis lies as close to, or closer to, Canis than to Dusicyon (Figs $2 \mathrm{~b}$ and $8 \mathrm{~b}$ ).

The Falkland Islands lie within the continental shelf, approximately $400 \mathrm{~km}$ east of Patagonia $\left(5 \mathrm{I}-53^{\circ} \mathrm{S}, 57-6 \mathrm{I}^{\circ} \mathrm{W}\right)$. It is possible that at some stages of the Pleistocene the islands were connected with the mainland and may have supported a mammalian fauna. If so, it could be argued that the canid became isolated on the islands when they became finally detached from the continent. It would be most surprising, however, for the only relic of a Pleistocene fauna to be one large carnivorous species. It seems much more likely that $D$. australis was taken to the Falkland Islands as a domestic animal by early man. This could have happened thousands of years ago, allowing the population to evolve into an autochthonous race, similar to the dingo. Support for this view is seen in the white tip of the tail (all other Dusicyon species have a black tip), the enlarged frontal sinuses and the wide muzzle when compared with other species of Dusicyon. These characters can signify domestication and frequently occur in the dingo.

If the Falkland Island 'wolf' was descended from domesticated animals it is perhaps possible that a species of Dusicyon was the progenitor rather than a species of Canis. Hamilton Smith (I839), amongst other early writers, described a domesticated form of D. culpaeus but he stated that the Indians preferred imported European dogs and that these were superseding the indigenous varieties.

Unless further evidence from fossil or archaeological sources comes to light, the origin of $D$. australis must remain speculative and although the results of this analysis show that the species was quite distinct from the mainland canids, the evidence does not justify giving it separate generic status.

\section{Dusicyon culpaeus (Molina, I782)}

Colpeo fox

Distribution. Widespread throughout the Andes mountains and hilly regions of the western and southern countries of South America up to $4000 \mathrm{~m}$ (the 'Patagonian subregion' of Hershkovitz, I957, I972 ; see also Cabrera, I93I, I958 ; Langguth, I970).

Description. Variable in size - can be large and 'wolf-like'. Head, neck, ears and legs tawny or rufous. Underparts pale. Back and shoulders grey with agouti (banded) guard hairs. Underfur fawn. Tail bushy with black tip; length over half that of the head and body combined. 
Skull longer and narrower in the facial region than in Dusicyon australis. Frontal bones flat. Interparietal crest poorly developed. Palatine bones do not extend backwards beyond the posterior edge of $\mathrm{M}^{2}$. Canines and premolars simple and 'fox-like' as in $D$. australis. The metaconid of $\mathrm{M}_{1}$ higher than the level of the talonid as is usual in the Canidae.

Systematic position. Percentage similarity to 'near neighbours' :

$\begin{array}{ll}\text { All characters } & \\ \text { Dusicyon gymnocercus } & 93 \cdot 9 \\ \text { Dusicyon culpaeolus } & 93 \cdot 3 \\ \text { Dusicyon inca } & 92 \cdot 7 \\ \text { Dusicyon griseus } & 92 \cdot 7 \\ \text { Dusicyon fulvipes } & 90 \cdot 0\end{array}$

Skull and teeth only

Dusicyon inca $\quad 88 \cdot 5$

Dusicyon gymnocercus $88 \cdot \mathbf{I}$

Dusicyon culpaeolus $\quad 87 \cdot 5$

Canis simensis $\quad 86 \cdot 5$

Canis latrans $\quad 86 \cdot \mathrm{I}$

The three species Dusicyon culpaeus, Dusicyon gymnocercus and Dusicyon culpaeolus are phenetically very close to each other. The pelage characters are so similar that it would be hard to define differences between them and perhaps the distinctions that have been found in the skulls may be attributable to individual variation. It is not possible, however, within the scope of this work to discuss problems of speciation and although it may appear from the numerical taxonomy that these three should be placed in one species they could be valid biological entities whose ecological distributions do not overlap.

\section{Dusicyon culpaeolus (Thomas, I9I4)}

Distribution. Uruguay (Cabrera, I958).

Description. Very similar to Dusicyon culpaeus, but smaller. Considered by Kraglievich (I930) to be a subspecies of Dusicyon gymnocercus and it certainly bears the closest phenetic resemblance to this species.

Systematic position. Percentage similarity to 'near neighbours' :

$\begin{array}{ll}\text { All characters } & \\ \text { Dusicyon gymnocercus } & 96 \cdot 2 \\ \text { Dusicyon inca } & 93 \cdot 6 \\ \text { Dusicyon culpaeus } & 93 \cdot 3 \\ \text { Canis mesomelas } & 92 \cdot 9 \\ \text { Dusicyon griseus } & 92 \cdot 7\end{array}$

Skull and teeth only

Dusicyon gymnocercus $95 \cdot 3$

Canis adustus $\quad 92 \cdot 0$

Dusicyon inca $\quad 92 \cdot 0$

Canis mesomelas $\quad 9 \mathrm{I} \cdot 9$

Dusicyon fulvipes $\quad 89 \cdot \mathbf{I}$

D. culpaeolus was not known as a separate species until the description of Thomas (I9I4) which was made from one skull and skin in the British Museum. Further examination might show that it should be included, with $D$. gymnocercus, in $D$. culpaeus. 


\section{Dusicyon gymnocercus (Fischer, I8I4)}

Azara's fox

Distribution. Paraguay, northern Uruguay, southeastern Brazil and eastern Argentina (Cabrera, I93I, I958).

Description. Like Dusicyon culpaeolus the phenetic characters of this species show close similarity to Dusicyon culpaeus, from which it differs only in the shorter, wider rostrum and more uniform pelage.

Systematic Distribution. Percentage similarity to 'near neighbours' :

$\begin{array}{ll}\text { All characters } & \\ \text { Dusicyon culpaeolus } & 96 \cdot 2 \\ \text { Dusicyon griseus } & 95 \cdot 5 \\ \text { Dusicyon fulvipes } & 94 \cdot 3 \\ \text { Dusicyon culpaeus } & 93 \cdot 9 \\ \text { Dusicyon inca } & 93 \cdot 8\end{array}$

Skull and teeth only

Dusicyon culpaeolus $\quad 95 \cdot 3$

Dusicyon griseus $\quad 9 \mathrm{I} \cdot 8$

Dusicyon fulvipes $\quad 9 \mathrm{I} \cdot 8$

Canis adustus $\quad 9 \mathrm{I} \cdot 5$

Canis mesomelas $\quad 90 \cdot 7$

Like D. culpaeolus this form may prove to be conspecific with D. culpaeus.

\section{Dusicyon inca (Thomas, I9I4)}

Distribution. Peru at $4000 \mathrm{~m}$ (Cabrera, I958).

Description. A fairly large canid similar in size to Dusicyon culpaeus but distinguishable from it by a more evenly grizzled pelage. Tail with a distinct black tip. Chin black, ears and outer sides of legs a dull tawny brown. Underparts brownish white.

Skull similar to that of D. culpaeus.

Systematic position. Percentage similarity to 'near neighbours' :

$\begin{array}{ll}\text { All characters } & \\ \text { Dusicyon gymnocercus } & 93 \cdot 8 \\ \text { Dusicyon culpaeolus } & 93 \cdot 6 \\ \text { Dusicyon culpaeus } & 92 \cdot 7 \\ \text { Dusicyon fulvipes } & 9 \mathrm{I} \cdot 3 \\ \text { Dusicyon griseus } & 90 \cdot 3\end{array}$

Skull and teeth only

Dusicyon culpaeolus $\quad 92 \cdot 0$

Dusicyon gymnocercus $88 \cdot 8$

Dusicyon culpaeus $\quad 88 \cdot 5$

Canis adustus $\quad 88 \cdot 3$

Canis mesomelas $\quad 88 \cdot 0$

This is another of Thomas's species that was described from a single skull and skin (the type is in the British Museum), and like Dusicyon culpaeolus it is possible that a study of further material might show that it should be included with $D$. culpaeus. It should be pointed out, however, that the pelage of the one skin of D. inca in the British Museum is distinguishable from that species and in fact more closely resembles that of Dusicyon griseus. 


\section{Dusicyon griseus (Gray, I836)}

Argentine grey fox

Distribution. The plains and low mountains of Patagonia, western Argentina and Chile (Cabrera, I93I, I958).

DEscription. A small species. Ears large, head rust-coloured flecked with white. Agouti guard hairs with pale underfur giving a generally pale appearance to the back. Underparts pale grey. Feet tawny. Tail long and moderately bushy. The pelage of this species looks very like that of Dusicyon fulvipes, Dusicyon inca, Dusicyon sechurae and Dusicyon vetulus but (from the skins in the British Museum) it is less red than $D$. fulvipes and more red than the remaining species.

Skull small and 'fox-like' with faintly marked temporal ridges enclosing a wide lyriform sagittal area. Teeth widely spaced and 'fox-like'.

Systematic position. Percentage similarity to 'near neighbours' :

$\begin{array}{ll}\text { All characters } & \\ \text { Dusicyon gymnocercus } & 95 \cdot 5 \\ \text { Dusicyon fulvipes } & 94 \cdot 4 \\ \text { Dusicyon culpaeolus } & 92 \cdot 7 \\ \text { Dusicyon culpaeus } & 92 \cdot 7 \\ \text { Vulpes bengalensis } & 9 \mathrm{I} \cdot \mathrm{I}\end{array}$

Skull and teeth only

Dusicyon fulvipes $\quad 92 \cdot 8$

Dusicyon gymnocercus $9 \mathrm{r} \cdot 9$

Vulpes velox $89 \cdot 0$

Dusicyon culpaeolus $\quad 87 \cdot 9$

Vulpes bengalensis $\quad 86 \cdot 9$

The skull of Dusicyon griseus has little to distinguish it from that of Dusicyon culpaeus except for its small size and lack of interparietal crest (absence of a crest appears to be associated with small size in the Canidae).

\section{Dusicyon fulvipes (Martin, I837)}

Darwin's fox, Chiloe fox

Distribution. The southern part of the Island of Chiloe. This is one of the very many islands that lie off the coast of Chile between latitudes $40-45^{\circ}$, separated from the mainland by a narrow channel, the Gulf of Corcovado.

Description. Smaller than Dusicyon griseus with a uniformly dark and rufous pelage. The ears, head and legs are tawny, the back dark grey with agouti guard hairs. The tail is neither long nor bushy but has a black tip.

Skull as in D. griseus but smaller.

Systematic position. Percentage similarity to 'near neighbours' :

$\begin{array}{ll}\text { All characters } & \\ \text { Dusicyon griseus } & 94 \cdot 4 \\ \text { Dusicyon gymnocercus } & 94 \cdot 3 \\ \text { Dusicyon sechurae } & 93 \cdot \mathrm{I} \\ \text { Dusicyon culpaeolus } & 92 \cdot 7 \\ \text { Dusicyon inca } & 9 \mathrm{I} \cdot 3\end{array}$

All characters

Dusicyon griseus

Dusicyon sechurae

Dusicyon inca

$94^{\circ} 4$

$94^{\circ} 3$

$92 \cdot 7$

$9 \mathrm{I} \cdot 3$
Skull and teeth only

$\begin{array}{ll}\text { Dusicyon griseus } & 92 \cdot 8 \\ \text { Dusicyon gymnocercus } & 9 \mathrm{I} \cdot 8 \\ \text { Cerdocyon thous } & 90 \cdot 0 \\ \text { Dusicyon culpaeolus } & 89 \cdot \mathrm{I} \\ \text { Vulpes chama } & 89 \cdot 0\end{array}$


It appears that this canid has always been somewhat rare or otherwise very shy and not many specimens have been collected. Osgood (I943:72) described how he trapped a pair of adults on the beach in I922. These two were very similar in pelage characters and skull conformation to Darwin's specimen. Osgood stated that there is a close agreement in characters between Dusicyon fulvipes and D. griseus and suggested that Darwin's fox is merely an island form of $D$. griseus rather than a separate species. The results of this analysis support Osgood's suggestion.

Remarks. The type specimen of this species was collected by Darwin and the skull and skin are now in the British Museum (no. 55.I2.24.43I) together with one other skull and skeleton (no. 5I.Ir.8.4 (996a) purchased from Mr Brandt). The identification of this second specimen is not certain, however, because the original entry in the catalogue has the word 'Chili', and there is no indication that the animal came from the Island of Chiloe. The following account of the 'fox' that Darwin collected may be quoted from his Voyage of the Beagle (1860 : 280) :

'December 6th. I834. In the evening we reached the island of San Pedro, where we found the Beagle at anchor. In doubling the point, two of the officers landed to take a round of angles with the theodolite. A fox (Canis fulvipes), of a kind said to be peculiar to the island, and very rare in it, and which is a new species, was sitting on the rocks. He was so intently absorbed in watching the work of the officers, that I was able, by quietly walking up behind, to knock him on the head with my geological hammer. This fox, more curious or more scientific, but less wise, than the generality of his brethren, is now mounted in the museum of the Zoological Society.'

\section{Dusicyon sechurae (Thomas, I900)}

Sechura desert fox

Distribution. The arid coastal zone of northwestern Peru and southwestern Ecuador, including the Sechura desert (Cabrera, I93I, I958).

DEscription. A small light species with pale agouti guard hairs and fawn underfur. Cream to fawn underparts. Little or no rufous colouring on the body. Tail with distinct black tip.

Skull small with lyriform sagittal area and no interparietal crest. Palatine bones extend backwards beyond the posterior edge of $\mathrm{M}^{2}$. Teeth small with 'fox-like' canines.

Systematic position. Percentage similarity to 'near neighbours' :

$\begin{array}{ll}\text { All characters } & \\ \text { Dusicyon vetulus } & 94 \cdot 5 \\ \text { Dusicyon fulvipes } & 93 \cdot \mathrm{I} \\ \text { Dusicyon gymnocercus } & 92 \cdot 6 \\ \text { Vulpes pallida } & 9 \mathrm{I} \cdot \mathrm{O} \\ \text { Dusicyon culpaeolus } & 90 \cdot 4\end{array}$

Skull and teeth only

Dusicyon vetulus $\quad 92 \cdot 1$

Vulpes chama $\quad 89 \cdot 8$

Dusicyon australis $\quad 88 \cdot 6$

Dusicyon fulvipes $\quad 88 \cdot 5$

Vulpes velox $\quad 87 \cdot 6$

In pelage characters this species lies close to Dusicyon griseus and Dusicyon vetulus. Its small size may be an adaptation to desert conditions. 
Dusicyon vetulus (Lund, I839)

Hoary fox

Distribution. The most northeastern of the species of Dusicyon that have been described so far. Found in south-central Brazil, Minas Gerais and Mato Grosso.

Description. The smallest species of Dusicyon, similar in size to the smallest true foxes, for example Vulpes pallida. Pelage as for Dusicyon sechurae but with a marked dark stripe along the dorsal line of the tail.

Skull small with faintly marked temporal ridges, a very narrow lyriform sagittal area and a slight interparietal crest. Teeth small with widely spaced premolars and reduced upper carnassial $\left(\mathrm{P}^{4}\right)$. Canines sharply pointed and 'fox-like'. Anterior part of the frontal bones slightly swollen.

Systematic position. Percentage similarity to 'near neighbours' :

All characters

Dusicyon sechurae Dusicyon gymnocercus

Vulpes bengalensis

Dusicyon fulvipes

Dusicyon griseus
$94 \cdot 5$

$9 \mathrm{I} \cdot 2$

$90 \cdot 1$

$90 \cdot 0$

$89 \cdot 9$
Skull and teeth only

Dusicyon sechurae $\quad 92 \cdot 1$

Vulpes bengalensis $\quad 86 \cdot 0$

Dusicyon australis $\quad 85 \cdot 4$

Vulpes chama $85 \cdot 2$

Canis mesomelas $\quad 84 \cdot 6$

This species is noted for its small teeth and reduced carnassials which, combined with its somewhat isolated distribution in the central and eastern parts of the continent, have inclined previous authors to place it in a separate genus. The first description of the species was by Burmeister (I854:99) who created the genus Lycalopex for it. This was followed by Gray (I868) and by all subsequent authors until Osgood (I934) reduced Lycalopex to a subgenus of Dusicyon. Cabrera (I958) and Simpson (I945) accepted this change and this nomenclature has been in general use up to the present. Langguth (I970, I975) has, however, reverted to classifying the species in a separate genus, that is, Lycalopex vetulus.

Although the two-dimensional plots show that Dusicyon vetulus lies somewhat on the edge of the Dusicyon group the analysis provides no evidence that the species should be separated at the generic level and for all phenetic characters it is clear that it lies very close to Dusicyon sechurae. The reduction in the size of the teeth may be more apparent than real for they are in proportion to the small size of the skull.

\section{Dusicyon thous (L.)}

\section{Common zorro, crab-eating fox}

Distribution. Savannah and woodland areas of northeastern South America, Columbia, Guiana, Brazil and south into northern Argentina (Cabrera, I93I, I958 ; Hershkovitz, I957 ; Langguth, I970). 
DESCRIPTION. A fairly small, dark canid with a grizzled-brown or grey pelage. The legs may be tawny, underparts brownish-white and ears ochreous or rufous. The tail is fairly long, bushy and either totally dark or with a black tip. Ears short. The caecum was said by Garrod (I873) to be nearly straight rather than convoluted as in most canids.

Temporal ridges faintly marked and enclosing a lyriform sagittal area. Frontal sinuses well developed and nasal bones slightly swollen in the facial region. Teeth large but canines not particularly long.

Systematic position. Percentage similarity to 'near neighbours' :

All characters

Dusicyon fulvipes

Dusicyon griseus

Dusicyon microtis

Dusicyon gymnocercus

Dusicyon culpaeolus

$9 \mathrm{I} \cdot \mathrm{I}$
$86 \cdot 7$
$86 \cdot \mathbf{I}$
$85 \cdot 3$
$85 \cdot 3$

Skull and teeth only

Dusicyon fulvipes $\quad 90 \cdot 0$

Dusicyon gymnocercus $\quad 88 \cdot 4$

Dusicyon culpaeolus $\quad 86 \cdot 2$

Dusicyon microtis $\quad 85 \cdot 6$

Canis mesomelas $\quad 84 \cdot 3$

Following Thomas (I9I4) many authors have separated the zorro from Dusicyon and placed it in either the subgenus or genus Cerdocyon Hamilton Smith, I839. Cabrera (I93I) distinguished the species from Dusicyon at the generic level on the long dark tail, large feet and characters of the molar teeth and mandibular condyle. The present analysis shows that, although the species lies somewhat apart from the main Dusicyon group for some characters, for example the somewhat enlarged frontal sinuses and dark pelage, the numerical results provide no evidence that would justify separate generic status.

\section{Ducisyon microtis (Sclater, I882)}

\section{Small-eared zorro}

Distribution. Tropical forests of the Amazonian basin in Brazil, Peru, Ecuador and Colombia. From sea level to Iooo m (Hershkovitz, I957, I96I). Classified as rare by the Red data book (Goodwin \& Holloway, I972).

Description. Larger than the common zorro with a large head, very short, rounded ears, short legs and a long bushy tail. Distinctive, dark, grizzled brown pelage with dark underparts except in the pelvic region where the hair is lighter in colour. The behaviour of this species in captivity has been described by Hershkovitz (I96I).

Temporal ridges strongly developed forming a raised, narrow, slightly lyriform sagittal area (as in Dusicyon australis). Frontal sinuses quite large as in Dusicyon thous, and nasal bones slightly swollen in the facial region. Canines long and 'fox-like'. Cheek-teeth robust. 
Systematic position. Percentage similarity to 'near neighbours' :

$\begin{array}{lr}\text { All characters } & \\ \text { Dusicyon thous } & 86 \cdot \mathbf{I} \\ \text { Canis adustus } & 84 \cdot 4 \\ \text { Dusicyon fulvipes } & 84 \cdot 3 \\ \text { Dusicyon gymnocercus } & 82 \cdot 9 \\ \text { Dusicyon sechurae } & 82 \cdot 9\end{array}$

Skull and teeth only

Canis adustus $\quad 90 \cdot 4$

Dusicyon gymnocercus $89 \cdot 7$

Canis mesomelas $\quad 87 \cdot 9$

Dusicyon culpaeolus $\quad 87 \cdot 8$

Dusicyon sechurae $\quad 86 \cdot 6$

As with most other members of the South American Canidae there has been a fair amount of vacillation in the classification of the small-eared zorro. Thomas (IgI4) placed it with the common zorro in the genus Cerdocyon Hamilton Smith, I839. Osgood (I934), on the other hand, believed it to be a true Dusicyon within the subgenus Dusicyon, whilst he placed only D. thous in the subgenus Cerdocyon. Cabrera (I940: I4) considered the small-eared zorro to be quite distinct from Dusicyon and he placed it in a new genus Atelocynus Cabrera, I940. Simpson (I945 : I09) noted the new genus but did not use it in his classification. Hershkovitz (I96I), however, fully supported Cabrera and believed that the new genus was valid. His reasons were based on the combination of characters that appear to distinguish the small-eared zorro from the rest of the Dusicyon species; these being the distinctive pelage, large size, small ears, large heavy teeth and development of the mandibular condyle as in D. thous. These characters were observed by Osgood who, nevertheless, retained the species within the genus Dusicyon.

The results of this analysis show that Dusicyon microtis is phenetically fairly close to $D$. thous and that it lies on the periphery of the main Dusicyon group. It could only be argued that it should be given separate generic status if this was also done for $D$. australis. Hershkovitz (I972:390) believes that $D$. microtis is a specialized canid adapted to living in tropical rain forest areas.

\section{Genus CHRYSOCYON Hamilton Smith, I839}

One species.

\section{Chrysocyon brachyurus (Illiger, I8II)}

\section{Maned wolf}

Distribution. Tall grasslands and the outskirts of forests in eastern and southern Brazil, Paraguay, eastern Bolivia and northern Argentina (Cabrera, I958 ; Hershkovitz, I972:390). Classified as vulnerable by the Red data book (Goodwin \& Holloway, I972).

Description. The largest of the South American canids with a very striking appearance, 'like a fox on stilts'. Shy and solitary, feeding on small prey and some vegetable matter. It is believed that it never digs, and indeed this might be difficult with its long legs. The pelage is distinctive and different from that of any other canid. The hair is long and reddish in colour over the whole body. Muzzle and 
chin dark, anterior part of throat white and inside of ears white. Feet black from the hocks, which are elongated, downwards. White tuft to rather short bushy tail. The hair along the nape of the neck and back is longer than the rest and dark coloured. Ears large and erect. Flower (I879) recorded that the caecum of a specimen that died in the Zoological Gardens was quite straight.

Skull large and elongated. Frontal bones flat. Temporal ridges close and fused into a well-developed interparietal crest. Palatine bones extend slightly further back than the posterior edge of $\mathrm{M}^{2}$. Auditory bullae relatively very small. Teeth simple, widely spaced and 'fox-like'. Premolars simple and high-crowned. $\mathrm{P}^{4}$ short.

Systematic position. Percentage similarity to 'near neighbours' :

$\begin{array}{ll}\text { All characters } & \\ \text { Canis simensis } & 79 \cdot 9 \\ \text { Dusicyon gymnocercus } & 74 \cdot 7 \\ \text { Dusicyon culpaeolus } & 74 \cdot 5 \\ \text { Dusicyon inca } & 73 \cdot 4 \\ \text { Dusicyon microtis } & 73 \cdot 4\end{array}$

$\begin{array}{lr}\text { Skull and teeth only } & \\ \text { Canis simensis } & 88 \cdot 7 \\ \text { Canis adustus } & 88 \cdot 7 \\ \text { Dusicyon culpaeolus } & 84 \cdot 3 \\ \text { Dusicyon gymnocercus } & 83 \cdot 6 \\ \text { Canis lupus } & 82 \cdot 8\end{array}$

C. brachyurus clearly stands apart on its own. It is not a fox, as is often maintained ; neither does it lie close to the Canis group, for although the 'near neighbours' tables do show a fairly high level of similarity with Canis simensis and Canis adustus these are the two species of Canis that are closest to the Dusicyon group. A rather low level of similarity with the genus Dusicyon is therefore probably the best interpretation of the affinities of the maned wolf and its position on the two-dimensional plots supports this view.

Genus SPEOTHOS Lund, I839

One species.

Speothos venaticus (Lund, I842)

Bush dog

Distribution. Common throughout tropical rainforests and savannah areas in the Brazilian subregion of South America. Also found in one locality in southeastern Panama where Hershkovitz (I972 : 359) suggests that it may have been introduced by man (Cabrera, I958).

Description. Small, rather 'otter-like' with short legs and tail. Head heavy with a wide muzzle and small ears. Head and neck ochreous fawn or tawny merging into dark brown or black along the back and tail. Chin and underparts as dark as the back. There may be a light patch behind the chin on the throat. Skin of body yellow or tan in colour. The caecum is said to be straight as in Chrysocyon brachyurus (Flower, I880:73). The brain has relatively high and massive frontal lobes 
(reflected in the swollen frontal lobes of the skull) and a relatively untwisted cerebellar vermis (Radinsky, I973). A social carnivore that hunts in packs of up to ten animals and swims well.

As observed by Huxley (I880), the occiput is unique amongst canids in being drawn out into a short tube (unfortunately this character was missed and has not been taken into account in the numerical analysis). Facial region short with swollen frontal bones producing a slightly convex skull profile. Dentition reduced with $\mathrm{M}^{2}$ nearly always missing and $\mathrm{M}_{3}$ always absent, as in Cuon alpinus. Canine teeth 'dog-like', that is short and robust. Upper premolars $\mathrm{I}-3$ unusually thick in cross-section and with no posterior secondary cusps. The talonid or heel of the lower carnassial $\left(\mathrm{M}_{1}\right)$ has only one cusp as in C. alpinus and Lycaon pictus (Table 5 ). Symphysis of the mandible very long and strongly ankylosed.

Systematic Position. Percentage similarity to 'near neighbours' :

All characters

Cuon alpinus

Dusicyon microtis

Lycaon pictus

Dusicyon australis

Bloodhoúnd
$73 \cdot 5$

$68 \cdot 2$

$67 \cdot 9$

$67 \cdot 8$

$67 \cdot 5$
Skull and teeth only

Cuon alpinus $87 \cdot 0$

Nyctereutes procyonoides $74 \cdot \mathbf{I}$

Lycaon pictus $\quad 73.7$

Dusicyon australis $\quad 72 \cdot 6$

Dingo

Speothos venaticus, L. pictus and $C$. alpinus have been placed in the subfamily Simocyoninae by Simpson (I945 : I09, 223) on palaeontological evidence. According to Matthew (I930: I28) there were two branches of primitive canids during the Miocene. One led to the present-day true canids (subfamily Caninae) whilst the second (the Simocyoninae), which was equally widespread and abundant, later became extinct except for these three representatives. The only diagnostic character that distinguishes the two groups is the development of the talonid of the lower carnassial as a single cusp or ridge in the Simocyoninae. In all other canids the talonid has two cusps and was described by Matthew as 'basined'.

One of the objects of the present work was to test the validity of this grouping on phenetic grounds. While it does appear that the three species are closer to each other than to any other groups on the basis of cranial and dental characters, the overall similarities are very low and it seems best to refrain from emphasizing their very few points of resemblance. Whatever the validity of their common origin they have clearly diverged very greatly and their recognition as isolated monospecific genera seems appropriate.

The bush dog is a highly social animal. Unfortunately there are no detailed studies of the behaviour of $C$. alpinus and the few observations that have been made on $S$. venaticus show that its behaviour patterns are markedly different from those of L. pictus. Some habits are shared, however. Both species practise communal sleeping and hunting, neither uses the gape or teeth-baring threats and neither has very highly developed tail-wagging behaviour (Kleiman, I967).

The behaviour of the bush dog is clearly interrelated with its body-shape and pelage characters. The ventral surface is seldom exposed because the animal has 
short legs and it therefore has no need for a colour contrasting with the back. The short legs may also be related to the lordosis-like posture held by the female during courtship. The female is said to lower her front legs and raise her hindquarters and tail, as cats do (Kleiman, I967:368). Similarly the lack of facial markings is probably related to the exaggerated submissive grin which exposes the molar teeth rather than a paler cheek region as in the other social canids.

Kleiman maintained (1967:37I) that S. venaticus and L. pictus cannot be allied on their behaviour patterns. It would certainly be remarkable if they could be, as the bush dog is highly specialized for hunting in the tropical rainforests of Brazil and the Cape hunting dog (L. pictus) for following the migrating herds of large mammals in the African savannah.

\section{Genus $\boldsymbol{C U O N}$ Hodgson, 1838}

One species.

\section{Cuon alpinus (Pallas, I8II)}

Dhole, red dog, Indian wild dog

Distribution. Montane forest areas of the Indian peninsula, Malaysia, Java, Sumatra, Burma and northwards into Korea, China and eastern U.S.S.R. Not found in Ceylon (Ellerman \& Morrison-Scott, I966). Formerly fairly common but now the distribution of the dhole is much reduced and it is rare. Classified as a vulnerable species by the Red data book (Goodwin \& Holloway, I972).

Description. A fairly large 'dog-like' canid with rounded ears and a long, moderately bushy tail. The legs are rather short, the pelage an evenly tawny or dark red colour with slightly darker tail and lighter underparts. The winter coat may be yellowish-grey in cold regions. A social carnivore that lives and hunts in packs.

As observed by Huxley ( $1880: 276$ ), there is a notable similarity between the skulls of Cuon alpinus and Lycaon pictus. In both species the facial region is short and wide, although more so in Lycaon than in Cuon, and the frontal and maxillary bones are swollen so that the skulls have a convex profile (as in Speothos venaticus). The palatine foramina are long in both species and the nasal bones widen at the point where they meet the suture between the frontal and maxillary bones (the nasals are often described as having a sigmoid shape). In both species the dentition is 'dog-like' and strongly developed except that $\mathrm{M}^{2}$ is reduced in size and, in Cuon, $\mathrm{M}_{3}$ is absent. Secondary posterior cusps are present on $\mathrm{P}^{2}, \mathrm{P}^{3}$, and on the lower premolars in both species. The talonid of the lower carnassial $\left(\mathrm{M}_{1}\right)$ has only one cusp in Cuon as it has in Speothos and Lycaon. This character was first observed by Major in 1872 (I900: 834). 
Systematic position. Percentage similarity to 'near neighbours' :

All characters

$\begin{array}{ll}\text { Dusicyon australis } & 79 \cdot 2 \\ \text { Dusicyon gymnocercus } & 78 \cdot 2 \\ \text { Canis latrans } & 77 \cdot 9 \\ \text { Dingo } & 77 \cdot 3 \\ \text { Canis aureus } & 77 \cdot 0\end{array}$

Skull and teeth only

Speothos venaticus $\quad 87 \cdot 0$

Lycaon pictus $\quad 80 \cdot 9$

Dingo $\quad 78 \cdot 6$

Dusicyon australis $\quad 76 \cdot 0$

Canis lupus $\quad 75 \cdot 2$

Pocock (I94I : I46) was not impressed with the assumed similarities between $C$. alpinus and $L$. pictus that had been described by previous authors and he was even less impressed by the similarities between Cuon and Speothos. Our numerical results, however, show that there are certain phenetic resemblances in the skulls and teeth of the three genera but the pelage and postcranial characters are widely different and although all three are social species without highly developed facial expressions it is not known whether there are any inherent behaviour patterns that link the three genera. Kleiman's comparative study (I967) did not include Cuon, and Lycaon is the only one of the three on which serious ethological studies have been carried out (van Lawick-Goodall, I970 ; Kühme, I965a, b).

Although the dhole may resemble the dingo and the Indian pariah dog in colouring and superficial appearance, the skull and teeth are so distinctive that it is most unlikely that this species has contributed to the ancestry of the domestic dog.

Genus LYCAON Brookes, 1827

One species.

\section{Lycaon pictus (Temminck, I820)}

\section{Hunting dog}

Distribution. Formerly widespread throughout the African savannah south of the Sahara wherever game was abundant, up to $2700 \mathrm{~m}$. Now becoming increasingly restricted to game reserves (Allen, I939; Ellerman et al., I953). Classified as a vulnerable species by the Red data book (Goodwin \& Holloway, I972).

Description. A large canid with long legs and a heavy, rather 'hyaena-like' head. Ears large, rounded and nearly naked. Body hair may be scant. Mottled pelage which is variable in pattern and colouring. The irregular spots may be black, brown, grey or white, on a basic colour of yellowish-grey or black. The muzzle is dark and may have a dark stripe leading along the side of the head. Tail moderately bushy with a white tip. This species is the only member of the Canidae in which the first digit is absent or vestigial in the fore feet as well as the hind feet. Highly social but has never been domesticated.

Short wide facial region with swollen frontal maxillary bones that give a convex shape to the skull profile, as in Cuon alpinus. The anterior palatine foramina are large and the nasal bones are wide. Frontal sinuses well developed. Interparietal 
crest may be pronounced. Dentition complete with strong, 'dog-like' canines and carnassials. Posterior secondary cusps are present on $\mathrm{P}^{2}, \mathrm{P}^{3}$ and on the lower premolars. The talonid of the lower carnassial, $\mathrm{M}_{1}$, has only one cusp, as in Speothos and Cuon.

Systematic position. Percentage similarity to 'near neighbours' :

All characters

Dusicyon australis

Cuon alpinus

Bloodhound

Dingo

Speothos venaticus

$71 \cdot 0$
$69 \cdot 7$
$68 \cdot 8$
$67 \cdot 9$
$67 \cdot 9$

Skull and teeth only

$\begin{array}{ll}\text { Dingo } & 8 \mathrm{r} \cdot 8 \\ \text { Cuon alpinus } & 80 \cdot 9 \\ \text { Canis lupus } & 79 \cdot 4 \\ \text { Canis aureus } & 77 \cdot 6 \\ \text { Bloodhound } & 77 \cdot 4\end{array}$

The numerical results show that Lycaon pictus is a most aberrant canid and there can be no dispute about its generic status. The phenetic relationships of this species with Speothos and Cuon have already been discussed in the sections on these genera.

Remarks. The hunting dog occupies the 'wolf niche' in Africa. The species has evolved a system of ritualized communal feeding whereby a whole pack can be sustained on the hunting efforts of a few individuals (Kühme, I965a, b). This system is based on the regurgitation of food by the hunters for the juveniles and all members of the pack that have not joined in the killing of prey (usually antelope or gazelle). Many species of canid will regurgitate food for their young but in the hunting dog this habit is extended and has evolved into a basis for highly organized social behaviour. Although it is perhaps the most social of all canids the hunting dog has not evolved the elaborate facial expressions and signals of communication that are now so well known from studies of behaviour in the wolf. Fox (I970) suggested that the reasons for this are that the social organization of the hunting dog is based on individual dominant and subordinate relationships, mutual submission and strong group-orientated activities, rather than on a hierarchy of relationships as occurs within the wolf pack. He further suggests that communication by facial expression is important to groups of wolves that frequently undergo separation and congregation, whereas the hunting dog packs remain together as cohesive units for longer periods. Perhaps the strikingly individual markings of the hunting dog also assist in communication and identification of conspecifics.

\section{ACKNOWLEDGEMENTS}

Computer time for this project was kindly supplied by Rothamsted Experimental Station and we are most grateful to Miss Linda Jackson for her help in running the programs. Our thanks are also due to Miss Jenny Paul who assembled much of the data during tenure of a vacation studentship at the British Museum (Natural History). 
Canis lupus

Dingo

Bloodhound

\section{Canis latrans}

C. aureus

C. mesomelas

C. adustus

C. simensis

Vulpes vulpes

V. corsac

$V$. ferrilata

$V$. bengalensis

V. cana

V. rueppelli

V. pallida

V. zerda

V. chama

V. velox

$V$. cinereoargenteus

Alopex lagopus

Otocyon megalotis

Nyctereutes procyonoides

Dusicyon australis

D. culpaeus

D. culpaeolus

D. gymnocercus

D. inca

D. griseus

D. fulvipes

D. sechurae

D. vetulus

D. thous

D. microtis

Chrysocyon brachyurus

Speothos venaticus

Cuon alpinus

Lycaon pictus

\section{TABLE 4}

Characters of the skull

\begin{tabular}{|c|c|c|c|c|c|c|c|c|c|c|c|}
\hline I & 2 & 3 & 4 & 5 & 6 & 7 & 8 & 9 & Io & I I & 12 \\
\hline 226 & 65 & 33 & $5^{I}$ & 88 & 57 & I4 & 3 & 3 & 2 & I & 2 \\
\hline I80 & 64 & 32 & 50 & 80 & 57 & I4 & 2 & 3 & 2 & I & 2 \\
\hline $22 \mathrm{I}$ & 63 & 35 & 56 & 83 & 49 & 12 & 3 & 3 & 2 & I & 2 \\
\hline I 80 & 59 & 28 & $4^{8}$ & 93 & $5^{2}$ & I4 & 2 & 3 & 2 & I & 2 \\
\hline 160 & 65 & 34 & $5^{2}$ & 85 & 57 & I6 & 2 & 3 & 2 & I & 2 \\
\hline I 44 & 64 & 32 & $5^{I}$ & 79 & 59 & I6 & 2 & 3 & 2 & I & I \\
\hline I 49 & 60 & 30 & 50 & 89 & $5^{I}$ & I4 & 2 & 3 & 2 & I & I \\
\hline I83 & $5^{2}$ & 25 & 49 & 94 & 53 & I3 & I & 2 & 2 & I & I \\
\hline I30 & 55 & 29 & 54 & 88 & 54 & I5 & I & 2 & 2 & I & 0 \\
\hline II 2 & $5^{8}$ & $3^{I}$ & 53 & $8 I$ & 59 & I 7 & I & I & 2 & 0 & 0 \\
\hline I45 & 49 & 24 & $5^{I}$ & II 5 & 57 & I5 & 1 & I & 2 & 0 & 0 \\
\hline II 2 & $5^{8}$ & 29 & 50 & 89 & 56 & I8 & I & I & 2 & I & 0 \\
\hline 90 & $5^{8}$ & 26 & 45 & 87 & $5^{6}$ & I9 & 0 & 0 & 0 & 0 & 0 \\
\hline 102 & 57 & 27 & 47 & 94 & 55 & 20 & I & I & 2 & I & 0 \\
\hline 98 & 59 & 30 & $5^{I}$ & 83 & 55 & I8 & I & 0 & I & I & 0 \\
\hline 82 & 60 & 29 & 49 & 89 & 54 & 26 & 0 & 0 & 0 & 0 & 0 \\
\hline III & 60 & 30 & 50 & 83 & 55 & I8 & I & I & 2 & I & 0 \\
\hline II 4 & $5^{6}$ & 26 & 46 & 89 & 54 & I7 & I & I & I & I & 0 \\
\hline II9 & 55 & 28 & $5^{I}$ & 85 & $5^{6}$ & I6 & 2 & o & 2 & 2 & 0 \\
\hline 124 & 62 & 35 & $5^{6}$ & $8 I$ & $5^{6}$ & I6 & 1 & 2 & 2 & 0 & 0 \\
\hline II 4 & 54 & 32 & 60 & $8 \mathrm{I}$ & 54 & I7 & 2 & 0 & $\mathbf{I}$ & 2 & 0 \\
\hline I IO & 59 & 35 & 59 & 83 & 57 & I7 & I & 2 & 2 & 2 & 2 \\
\hline I 57 & 64 & 34 & 53 & 75 & & I5 & 2 & I & 2 & I & 2 \\
\hline I65 & 53 & 24 & 45 & 124 & 55 & I4 & 2 & 3 & 2 & I & I \\
\hline I39 & 57 & 29 & $5^{\circ}$ & $9 \mathrm{I}$ & $5^{6}$ & I5 & I & 2 & 2 & I & I \\
\hline I39 & 55 & 28 & $5^{I}$ & 9I & 53 & I6 & I & I & 2 & I & I \\
\hline I47 & 55 & 28 & 5 I & 98 & $5^{6}$ & I3 & I & 3 & 2 & 2 & I \\
\hline 120 & 55 & 27 & $4^{8}$ & 92 & $5^{I}$ & I5 & o & I & I & 0 & I \\
\hline II 5 & 59 & 30 & 50 & 93 & 54 & I6 & 0 & 0 & I & I & I \\
\hline II 7 & $5^{8}$ & 32 & 54 & 82 & 57 & I 5 & I & I & 2 & I & 2 \\
\hline IO4 & 65 & 36 & 55 & 74 & 59 & I9 & I & I & 2 & $\mathbf{I}$ & 2 \\
\hline 126 & 62 & $3^{I}$ & 50 & 90 & 53 & I5 & o & I & I & I & I \\
\hline I49 & 60 & 32 & 54 & 94 & $5^{8}$ & $I_{5}$ & 2 & I & 2 & I & I \\
\hline 213 & 54 & 28 & $5^{2}$ & 95 & $5^{6}$ & 12 & 3 & 3 & 2 & I & I \\
\hline I 24 & 67 & $4^{I}$ & 62 & 75 & $5^{8}$ & $I_{5}$ & I & 2 & 2 & 2 & 2 \\
\hline I 78 & 70 & 40 & 57 & 72 & $6 I$ & $\mathrm{I}_{5}$ & I & 3 & 2 & I & 2 \\
\hline I 88 & 76 & 47 & 62 & $6 I$ & 68 & $I_{5}$ & 2 & 3 & 2 & 0 & 2 \\
\hline
\end{tabular}


TABLE 4 cont.

Key to characters

I. Condylobasal length

2. Palate - greatest width as $\%$ of length of palate $(a: b)$.

3. Rostrum - width as \% of length of palate $(c: b)$.

4. Rostrum - width as \% of width of palate (c : a).

5. Premaxillae - anterior palatine length as $\%$ of width of rostrum (d:c).

6. Zygomatic width as \% of condylobasal length (e: $\mathrm{r})$.

7. Bullae - maximum length as \% of condylobasal length ( $f: I$ ).

8. Temporal ridges - size : $0=$ absent ; $3=$ highly developed.

9. Temporal ridges - proximity : $o=$ wide apart ; $3=$ fused.

Io. Interparietal crest : $0=$ absent ; $2=$ well developed.

II. Parietal bones - rugosity : $0=$ smooth ; $2=$ distinctly rugose.

I2. Post-orbital processes - convexity: $0=$ concave; $\mathbf{I}=$ flat ; $2=$ strongly convex.

13. Mandible - size of subangular lobe : $0-2$.

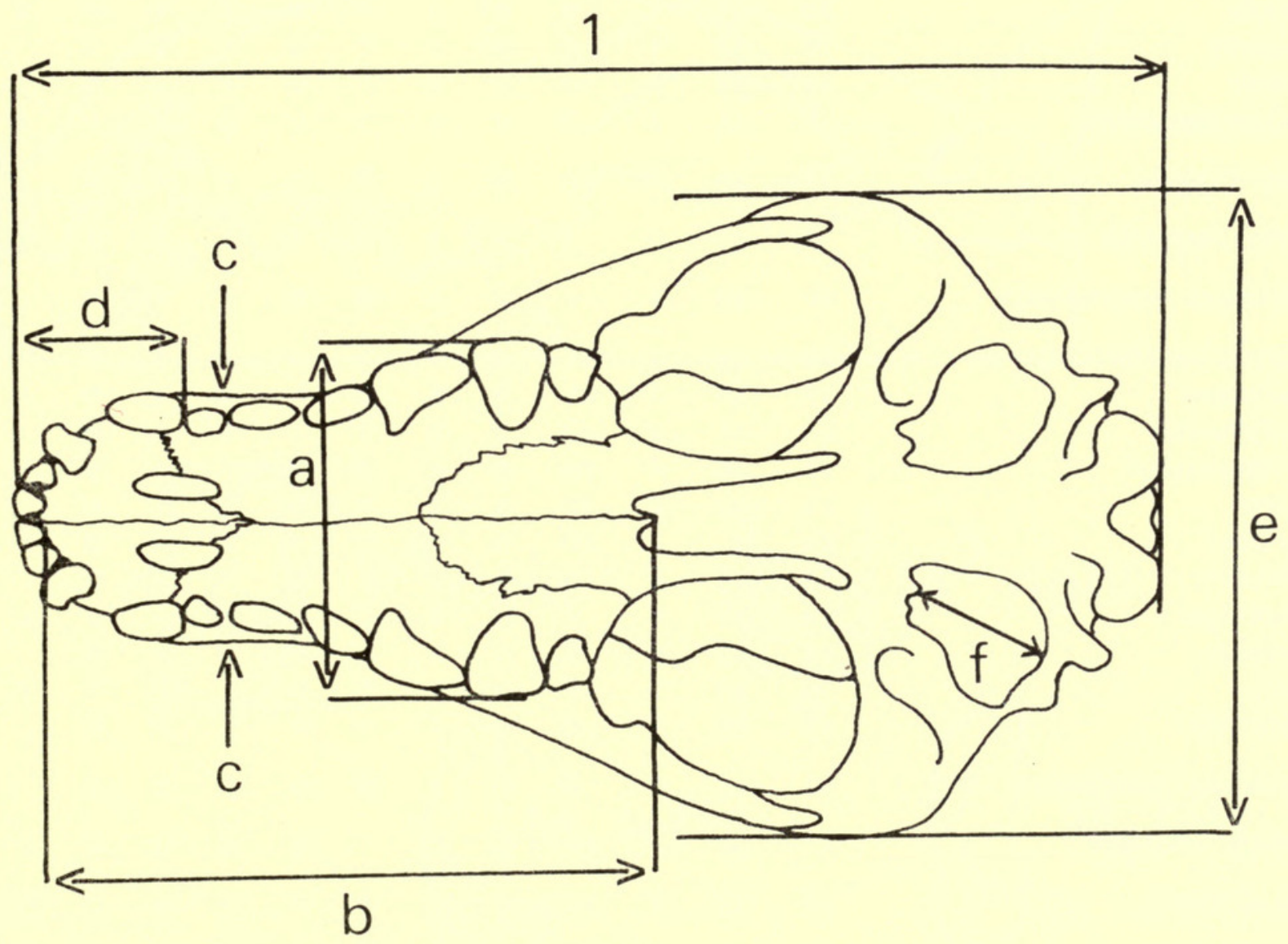


Canis lupus

Dingo

Bloodhound

Canis latrans

C. aureus

C. mesomelas

C. adustus

C. simensis

Vulpes vulpes

V. corsac

$V$. ferrilata

$V$. bengalensis

$V$. cana

V. rueppelli

$V$. pallida

V. zerda

V. chama

V. velox

$V$. cinereoargenteus

Alopex lagopus

Otocyon megalotis

Nyctereutes procyonoides

Dusicyon australis

D. culpaeus

D. culpaeolus

D. gymnocercus

D. inca

D. griseus

D. fulvipes

D. sechurae

D. vetulus

D. thous

D. microtis

Chrysocyon brachyurus

Speothos venaticus

Cuon alpinus

Lycaon pictus

\section{TABLE 5}

Characters of the teeth

upper

lower deciduous

\begin{tabular}{|c|c|c|c|c|c|c|c|c|c|c|c|c|}
\hline I & 2 & 3 & 4 & 5 & 6 & 7 & 8 & 9 & Io & $\overbrace{\text { II }}$ & I2 & $\underbrace{}_{13}$ \\
\hline II & 50 & 2 & II & 0 & I & 6 & o & I & I & o & o & I \\
\hline II & $4^{8}$ & 2 & II & 0 & I & 6 & 0 & I & I & 0 & 0 & I \\
\hline II & 54 & 2 & 9 & o & I & 6 & o & I & I & o & o & I \\
\hline 12 & 42 & 2 & II & o & I & 7 & o & I & I & o & & \\
\hline II & 50 & 2 & Io & o & I & 6 & o & I & I & o & I & I \\
\hline II & $4^{I}$ & I & I I & o & I & 7 & o & I & I & 0 & I & I \\
\hline II & 40 & I & 9 & o & I & 7 & o & I & I & 0 & I & I \\
\hline I2 & 39 & I & 9 & 0 & I & 6 & o & I & I & 0 & I & I \\
\hline 12 & 37 & I & ro & o & I & 6 & o & I & I & 0 & I & 0 \\
\hline 12 & $4^{I}$ & I & Io & o & I & 6 & o & I & I & 0 & & \\
\hline$I_{4}$ & 35 & I & 9 & o & I & 6 & 0 & I & I & o & o & $\mathbf{I}$ \\
\hline 12 & 36 & I & 9 & o & I & 8 & o & I & I & o & I & 0 \\
\hline 9 & $3^{8}$ & o & I I & o & I & 7 & o & I & I & o & & \\
\hline 9 & 47 & I & Io & o & I & 7 & o & I & I & o & I & 0 \\
\hline Io & $4 \mathrm{I}$ & I & 8 & o & I & 8 & o & I & I & o & & \\
\hline IO & 35 & I & 9 & o & I & 8 & o & I & I & o & I & 0 \\
\hline I0 & 37 & I & 9 & o & I & 7 & o & I & I & o & & \\
\hline II & 37 & I & Io & o & I & 6 & o & I & I & 0 & & \\
\hline 8 & $5^{\mathrm{I}}$ & I & 8 & o & I & 7 & o & I & I & o & I & o \\
\hline II & 49 & 2 & Io & o & I & 6 & o & I & I & o & I & 0 \\
\hline 8 & 47 & o & 5 & I & I & 6 & I & I & I & I & I & 0 \\
\hline IO & $4^{6}$ & I & 9 & o & I & 6 & 0 & I & I & o & & \\
\hline I2 & 43 & I & II & o & I & 6 & 0 & I & I & o & & \\
\hline 13 & 36 & I & IO & o & I & 7 & o & I & I & o & I & o \\
\hline II & $4^{I}$ & 2 & to & o & I & 7 & o & I & I & 0 & & \\
\hline II & 40 & I & Io & o & I & 7 & o & I & I & o & & \\
\hline 13 & 39 & 2 & II & o & I & 7 & o & I & I & o & & \\
\hline II & 37 & I & Io & o & I & 7 & o & I & I & 0 & I & o \\
\hline II & 35 & I & IO & o & I & 7 & o & I & I & o & & \\
\hline 12 & $3^{8}$ & I & 9 & o & I & 7 & 0 & I & I & o & I & I \\
\hline I2 & 37 & o & 7 & o & I & 8 & o & I & I & o & & \\
\hline 9 & 46 & I & I0 & o & $\mathbf{I}$ & 8 & 0 & I & I & o & I & I \\
\hline I3 & 39 & I & 9 & o & I & 7 & o & I & I & o & & \\
\hline I I & 44 & 0 & 8 & o & I & 6 & 0 & I & I & o & & \\
\hline I I & $5^{\circ}$ & 2 & Io & o & o & & o & o & 0 & o & 0 & o \\
\hline IO & 53 & 2 & II & o & I & 4 & o & o & o & 0 & 0 & o \\
\hline I 2 & 50 & 2 & II & o & I & 5 & 0 & 0 & I & 0 & 0 & I \\
\hline
\end{tabular}




\section{TABLE 5 cont.}

Key to characters

I. $\mathrm{C}^{1}-$ height as $\%$ of condylobasal length $(\mathrm{a}: \mathrm{b})$.

2. $\mathrm{C}^{1}$-alveolar length as $\%$ of height $(\mathrm{c}: \mathrm{a})$.

3. $\mathrm{P}^{3}$ - posterior cusps present : $\mathrm{o}-2$.

4. $\mathrm{P}^{4}$ (carnassial) - length as $\%$ of condylobasal length $(\mathrm{d}: \mathrm{b})$.

5. $\mathrm{P}^{4}$ - shape : $\mathrm{O}=$ carnassial ; $\mathrm{I}=$ molariform.

6. $\mathrm{M}^{2}$ present : $\mathbf{O}-\mathbf{I}$.

7. $\mathrm{M}^{2}-$ greatest width as $\%$ of condylobasal length $(e: b)$.

8. $\mathrm{M}^{3}$ present : $\mathrm{O}-\mathrm{I}$.

9. $\mathbf{M}_{1}$ (carnassial) - two cusps on heel : $\mathbf{O}-\mathbf{I}$.

Io. $\mathrm{M}_{3}$ present : $\mathbf{O}-\mathbf{I}$.

II. $\mathrm{M}_{4}$ present : $\mathrm{O}-\mathrm{I}$.

I2. $\mathrm{DP}^{3}$ - protocone developed as a cusp : O-I.

13. DP4 - posterior border concave, so that metacone appears as a separate lobe : $\mathbf{0 - I}$.

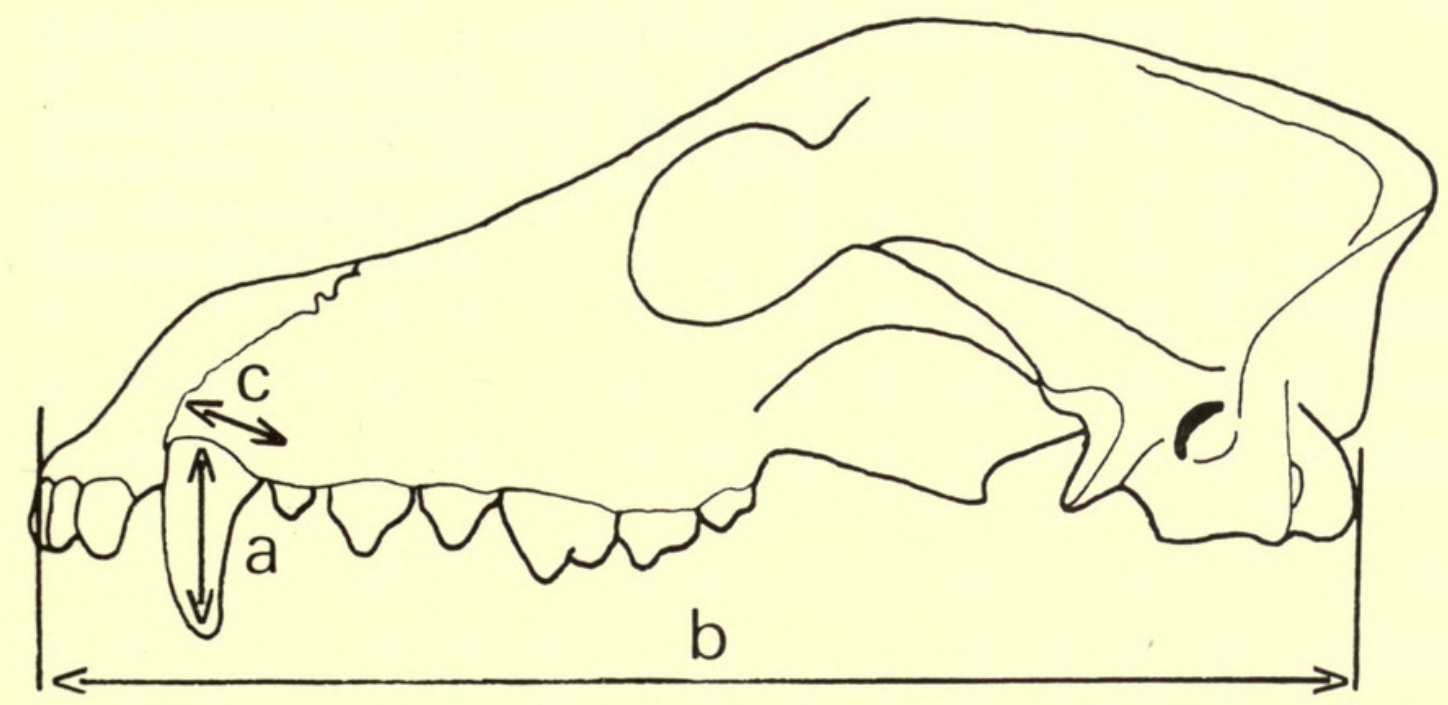

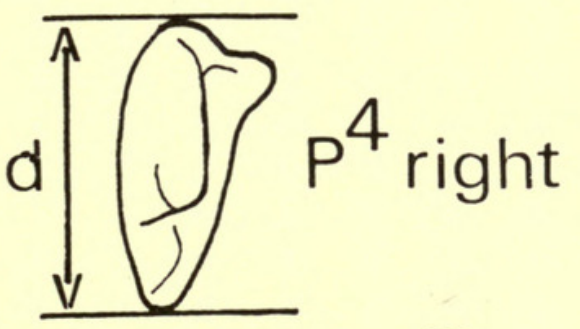

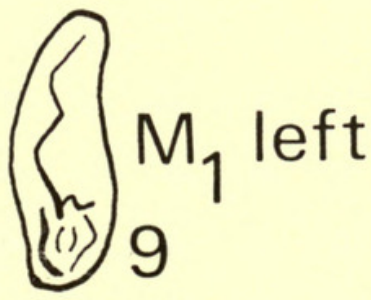

hound

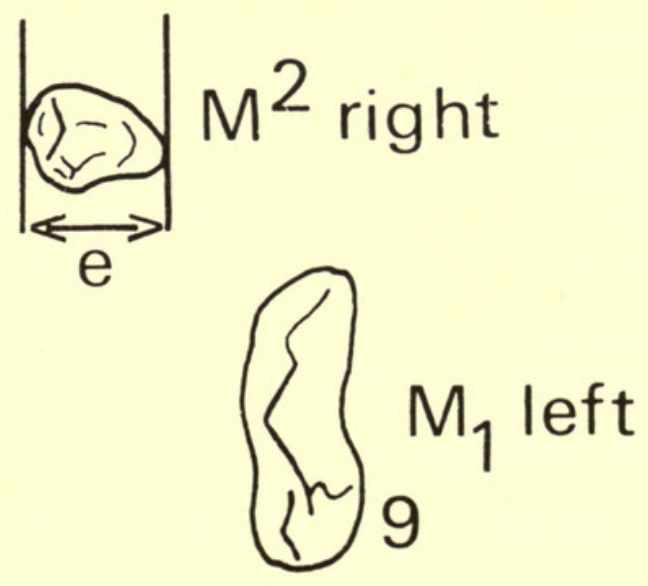

Lycaon pictus 


\section{TABLE 6}

Pelage of head and body

Canis lupus

Dingo

Bloodhound

Canis latrans

C. aureus

C. mesomelas

C. adustus

C. simensis

$V$. corsac

V. ferrilata

$V$. bengalensis

V. cana

V. rueppelli

$V$. pallida

V. zerda

V. chama

$V$. velox
Vulpes vulpes

\section{$\begin{array}{llllllllll}\text { I } & 2 & 3 & 4 & 5 & 6 & 7 & 8 & 9 & 10\end{array}$}

$\begin{array}{lllllllll}0 & 2 & 0 & 2 & I & I & 2 & 0\end{array}$

$\begin{array}{llllllllllllll}0 & 0 & 0 & 0 & I & I & 0 & I & 0\end{array}$

$\begin{array}{lllllllllllllllll}\text { I } & \text { I } & 0 & 0 & 0 & 0 & 0 & 0 & \text { I } & 0 & \text { I } & 0 & 2 & \text { I } & \text { I } & 2 & 0\end{array}$

$\begin{array}{lllllllllllllllll}I & 2 & 0 & 0 & 0 & 0 & 2 & 0 & I & 0 & I & 0 & 2 & I & I & 2 & 0\end{array}$

$\begin{array}{lllllllllllllllll}\text { I } & \text { I } & 0 & 0 & 0 & 0 & 2 & 0 & \text { I } & 0 & 3 & 0 & 2 & \text { I } & \text { I } & 2 & 0\end{array}$

$\begin{array}{lllllllllllllllll}I & I & 0 & 0 & 0 & 0 & 2 & 0 & 0 & I & 0 & 0 & 2 & I & I & 2 & 0\end{array}$

$\begin{array}{lllllllllllllllll}0 & 3 & 0 & 0 & 0 & 0 & I & 0 & I & 0 & 0 & 0 & \text { I } & \text { I } & \text { I } & \text { I } & 0\end{array}$

$\begin{array}{lllllllllllllllll}I & 3 & 0 & 0 & I & 0 & 2 & 0 & 0 & 0 & 0 & 0 & I & 2 & I & 2 & 0\end{array}$

$\begin{array}{lllllllllllllllll}\text { I } & I & 0 & 0 & I & 0 & 2 & 0 & 0 & 0 & 0 & 0 & I & I & I & I & 0\end{array}$

$\begin{array}{lllllllllllllllll}\text { I } & I & 0 & 0 & 0 & 0 & 2 & 0 & 0 & 0 & 0 & 0 & I & I & I & 2 & 0\end{array}$

$\begin{array}{lllllllllllllllll}\text { I } & I & 0 & 0 & \text { I } & 0 & 2 & 0 & 0 & 0 & 0 & 0 & \text { I } & \text { I } & \text { I } & 2 & 0\end{array}$

$\begin{array}{lllllllllllllllll}I & 0 & 0 & 0 & I & 0 & 2 & 0 & 0 & 0 & I & 0 & 0 & I & I & 2 & 0\end{array}$

$\begin{array}{lllllllllllllllll}\text { I } & I & 0 & 0 & I & 0 & 2 & 0 & 0 & 0 & 0 & 0 & I & I & I & 2 & 0\end{array}$

$\begin{array}{lllllllllllllllll}\text { I } & I & 0 & 0 & 0 & 0 & 2 & 0 & 0 & 0 & 0 & 0 & I & I & 0 & I & 0\end{array}$

$\begin{array}{lllllllllllllllll}0 & I & 0 & 0 & 0 & 0 & 2 & 0 & 0 & 0 & 0 & 0 & 0 & I & I & 2 & 0\end{array}$

$\begin{array}{lllllllllllllllll}\text { I } & I & 0 & 0 & 0 & 0 & 2 & 0 & 0 & 0 & 0 & 0 & I & 2 & I & 2 & 0\end{array}$

$\begin{array}{lllllllllllllllll}0 & I & 0 & 0 & I & 0 & 2 & 0 & 0 & 0 & 0 & 0 & I & I & I & 2 & 0\end{array}$

$\begin{array}{llllllllllllllllll}\text { Alopex lagopus } & 2 & 0 & 0 & 0 & 0 & 0 & I & 0 & 0 & 0 & 0 & 0 & 0 & 2 & 0 & 2 & I\end{array}$

$\begin{array}{llllllllllllllllll}\text { Otocyon megalotis } & \text { I } & \text { I } & 0 & \text { I } & 0 & 0 & 2 & 0 & 0 & 0 & 0 & 0 & \text { I } & 2 & \text { I } & 2 & 0\end{array}$

Nyctereutes

$\begin{array}{llllll}\text { procyonoides } & \text { I } & 2 & 0 & 0 & 0\end{array}$

Dusicyon australis $\mathrm{I} \quad 2 \quad \mathrm{O} \quad \mathrm{O} \quad \mathrm{O}$

D. culpaeus

D. culpaeolus

D. gymnocercus

D. inca

D. griseus

D. fulvipes

D. sechurae

$D$. vetulus

D. thous

D. microtis

Chrysocyon

brachyurus

Speothos venaticus

Cuon alpinus

Lycaon pictus

s

I

I

I I

I I

I I

2 I

I 0

I I

2 I

$3 \mathrm{I}$
00

00

00

00

00

o 0

00

o 0

o 0
00 $\begin{array}{lllllllllll}\text { I } & 0 & 0 & 0 & 0 & 0 & 2 & 2 & \text { I } & 2 & 0\end{array}$

$$
\begin{array}{llllllllll}
0 & 0 & 0 & 0 & 0 & I & I & I & 2 & 0
\end{array}
$$

$\begin{array}{lllllllllll}2 & 0 & 0 & 0 & I & 0 & \text { I } & \text { I } & \text { I } & \text { I } & 0\end{array}$

$\begin{array}{lllllllllll}2 & 0 & 0 & 0 & I & 0 & \text { I } & \text { I } & \text { I } & 2 & 0\end{array}$

$\begin{array}{lllllllllll}2 & 0 & 0 & 0 & 0 & 0 & I & I & I & I & 0\end{array}$

$\begin{array}{lllllllllll}2 & 0 & 0 & 0 & 0 & 0 & I & I & I & I & 0\end{array}$

$\begin{array}{lllllllllll}\text { I } & 0 & 0 & 0 & 0 & 0 & \text { I } & \text { I } & \text { I } & \text { I } & 0\end{array}$

$\begin{array}{lllllllllll}2 & 0 & 0 & 0 & 0 & 0 & I & I & I & I & 0\end{array}$

$\begin{array}{lllllllllll}2 & 0 & 0 & 0 & 0 & 0 & I & I & I & I & 0\end{array}$

$\begin{array}{lllllllllll}2 & 0 & 0 & 0 & 0 & 0 & \text { I } & \text { I } & \text { I } & \text { I } & 0\end{array}$

$\begin{array}{lllllllllll}\text { I } & 0 & \text { I } & 0 & \text { I } & 0 & 2 & \text { I } & \text { I } & \text { I } & 0\end{array}$

$\begin{array}{lllllllllll}I & 0 & 0 & 0 & 0 & 0 & 2 & 0 & I & I & 0\end{array}$ 


\section{TABLE 6 cont.}

Key to characters

I. Overall colour - intensity of black pigment: $0=$ absent; $I=$ grey or banded hairs ; 2 = general appearance dark ; 3 = very dark.

2. Overall colour-intensity of red pigment: $0=$ absent; $I=$ present as yellow or red underfur ; 2 = general appearance reddish or $\tan ; 3=$ extensive red colour.

3. Pelage boldly spotted : O-I.

4. Muzzle dark: O-I.

5. Facial mask between nose and eye : o-I.

6. Facial mask behind and below eye : $\mathbf{0 - I}$.

7. Mystacial vibrissae - length and thickness : o-2 (Hildebrand, I952b).

8. Crown - dark median stripe : $\mathbf{O}-\mathbf{I}$.

9. Neck and back with crest or mane : o-2.

Io. Side-dark and light longitudinal bands : $\mathrm{O}=$ absent ; $\mathrm{I}=$ present.

II. Back-dark longitudinal band: $0=$ absent; $I=$ narrow stripe; $2=$ wide stripe; $3=$ saddle.

12. Ventral pelage dark : $\mathbf{O}=$ paler than rest of body; $\mathbf{I}=$ dark.

I3. Guard hairs - coarseness : o-2.

14. Dorsal guard hairs - length in relation to body size : o-2.

15. Dorsal guard hairs banded (agouti) : o-I.

I6. Underfur - density : o-2.

I7. Seasonal colour change : o-I. 


\section{TABLE 7}

Pelage of extremities ; other external characters

Canis lupus

Dingo

Bloodhound

Canis latrans

Canis aureus

C. mesomelas

C. adustus

C. simensis

Vulpes vulpes

$V$. corsac

V. ferrilata

$V$. bengalensis

V. cana

V. rueppelli

V. pallida

V. zerda

V. chama

V. velox

$V$. cinereo-

argenteus tail

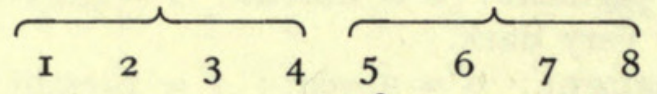

fore legs hind legs

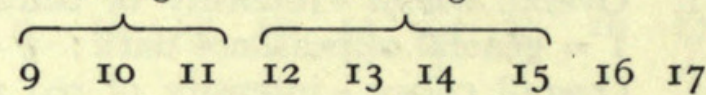

$\begin{array}{llllllll}\text { II } & 0 & 0 & \text { I } & 38 & 2 & \text { I } & 2\end{array}$

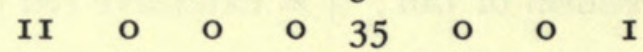

$\begin{array}{lllllllll}0 & I & I & 0 & 0 & 22 & 0 & 0 & \text { IO }\end{array}$

o 00

o 10 I

$\begin{array}{llllllll}0 & 0 & I & 0 & 0 & 20 & I & 0\end{array}$

$\begin{array}{llllllll}13 & 0 & 0 & 0 & 33 & 2 & \text { I } & \text { I }\end{array}$

$\begin{array}{lllll}0 & 0 & I & 0 & 0\end{array}$

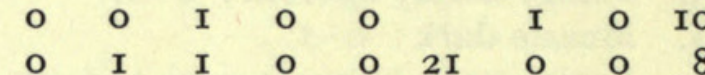

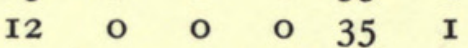

2

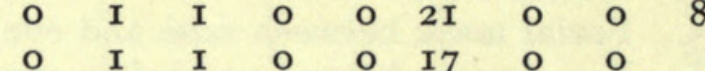

$\begin{array}{llllll}15 & 0 & 0 & 0 & 44 & 2\end{array}$

I 20000072

I I 0000025

2

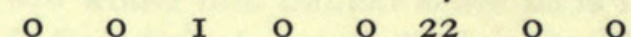

$\begin{array}{lllllll}0 & I & I & 0 & 0 & 22\end{array}$

$\begin{array}{lllllllll}5 & \mathrm{I} & 0 & 2 & 0 & 0 & 0 & 0 & 20\end{array}$

I6 o

90

59

00

o I I

8

$\begin{array}{lll}2 & I & 2\end{array}$

o 0

$\begin{array}{llllll}0 & 0 & 25 & 0 & 0 & 8\end{array}$

$\begin{array}{llllllllll}I_{5} & 0 & 0 & 0 & 58 & 2 & \text { I } & 2 & 0 & 0\end{array}$

00

o $\quad 0 \quad 19$

$\begin{array}{lll}0 & 0 & 24\end{array}$

o I 2 I

$\begin{array}{llllllllll}\text { I8 } & \text { O } & \text { I } & 0 & 7 \text { I } & 2 & 0 & \text { I } & 0 & 0\end{array}$

o 025

2I 0 o 0076

$\begin{array}{lllll}2 & I & 0 & 0 & 0\end{array}$

I 7 o

250

200

I7 o

o 60

6

$\begin{array}{llllllll}\text { I } & 2 & 0 & 0 & \text { I } & 0 & 0 & 24 \\ \text { I } & 2 & 0 & 0 & \text { I } & 0 & 0 & 25\end{array}$

o $\quad 0 \quad 26$

$\begin{array}{lll}0 & 0 & 26\end{array}$

年 


\section{TABLE 7 cont.}

Key to characters

I. Ears - length as \% of length of head and body (from skin labels and collector's notes, therefore only approximate).

2. Ears rounded : $\mathbf{O}-\mathbf{I}$.

3. Ears dark : o-I.

4. Ears - dark rim : O-I.

5. Tail - length as \% of length of head and body (as for $\mathrm{I}$ ).

6. Tail - bushiness : $0-2$.

7. Tail - dark patch on dorsal surface (see Hildebrand, I952b) : $0=$ absent ; $2=$ long.

8. Tail - tip dark : $0=$ white ; $I=$ same as rest of tail ; $2=$ black.

9. Fore legs entirely dark : $\mathbf{0 - I}$.

Io. Fore legs with black line on front : o-I.

II. Fore feet-claws on digit I : $\mathbf{O}-\mathbf{I}$.

I2. Hind legs dark: o-I.

I3. Hind feet-dark plantar surface : o-I.

I4. Hind feet-length as \% of length of head and body (as for I).

I5. Hind feet-claw on digit I : o-I.

I6. Skin - darkly pigmented : o-2.

I7. Mammae - total number (from Hildebrand, I952b). 


\section{TABLE 8}

Body proportions ; post-cranial skeleton ; internal anatomy

Canis lupus

Dingo

Bloodhound

Canis latrans

C. aureus

C. mesomelas

C. adustus

C. simensis

Vulpes vulpes

$V$. corsac

V. ferrilata

$V$. bengalensis

$V$. cana

V. rueppelli

V. pallida

V. zerda

V. chama

V. velox

$V$. cinereoargenteus

Alopex lagopus

Otocyon megalotis

$\begin{array}{cccc}\text { I } & \mathbf{2} & 3 & 4 \\ 7 \mathbf{I} & 79 & 39 & \text { I } \\ 67 & 73 & 43 & \text { I } \\ 69 & 77 & 43 & \text { I } \\ 70 & 78 & 4 \mathbf{I} & \text { I } \\ 62 & 73 & 44 & \text { I } \\ 66 & 75 & 46 & \text { 0 } \\ 7 \text { I } & 77 & 43 & \text { 0 }\end{array}$

$70 \quad 8$ baculum

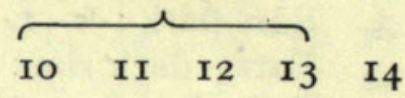

53

$\begin{array}{lll}97 & 8 & 42\end{array}$

I02 640

$\begin{array}{lll}99 & 8 & 39\end{array}$

45

$\begin{array}{llll}67 & 97 & 7 & 44\end{array}$

$\begin{array}{llll}67 & 100 & 6 & 43\end{array}$

$\begin{array}{lllll} & 0 & 0 & 0 & \\ 34 & 0 & 0 & 0 & 2 \\ 35 & 0 & 0 & 0 & \end{array}$

$\begin{array}{lll}93 & 7 & 46\end{array}$

Nyctereutes procyonoides $59 \quad 69 \quad \begin{array}{lllllllllllll}42 & 2 & 0 & 53 & 95 & 8 & 43 & 50 & 0 & 0 & 0 & \text { I }\end{array}$

Dusicyon australis

D. culpaeus

D. culpaeolus

$\begin{array}{llllllll}65 & 76 & 38 & \text { I } & \text { o } & 63 & 93 & 7\end{array}$

\begin{tabular}{lllll} 
& & & & 2 \\
\hline & 0 & 0 & 2
\end{tabular}

D. gymnocercus

D. inca

D. griseus

D. fulvipes

$\begin{array}{lll}63 & 78 & 40 \\ 68 & 83 & 39 \\ & & \\ 66 & 78 & 39 \\ 59 & 73 & 39\end{array}$

$\begin{array}{lll}70 & 79 \quad 34\end{array}$

r 076

897

49

$\begin{array}{llll}43 & 0 & 0 & 0\end{array}$

D. sechurae

$D$. vetulus

D. thous

D. microtis

$\begin{array}{lllll}64 & 75 & 38 & \text { I } & 0\end{array}$

956

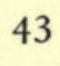

$\begin{array}{llll}43 & 0 & 0 & 0 \\ 43 & 0 & 0 & 0\end{array}$

$\begin{array}{lll}57 & 67 & 40\end{array}$

$\begin{array}{llllll}57 & 67 & 4^{\mathrm{I}} & \mathrm{I} & \mathrm{O} & 54\end{array}$

$\begin{array}{llll}47 & 0 & 0 & 0\end{array}$

$\begin{array}{llllll}48 & 43 & 0 & 0 & 0 & \text { I }\end{array}$

$\begin{array}{lllllllllllllll}\text { Chrysocyon brachyurus } & 92 & 103 & 47 & 2 & 0 & 60 & 95 & 6 & 49 & 34 & 0 & 0 & \text { 1 } & \text { 0 }\end{array}$ $\begin{array}{llllllllll}\text { Speothos venaticus } & 5^{2} & 5^{8} & 37 & \text { o } & \text { 0 } & 7 \text { I } & \text { I08 } & 8 & 37\end{array}$

Cuon alpinus

Lycaon pictus

$\begin{array}{lllllllll}60 & 70 & 35 & 2 & 0 & 60 & 104 & 8 & 42\end{array}$

$\begin{array}{llllll}68 & 74 & 38 & \text { O } & \text { I } & 68\end{array}$

$97 \quad 7 \quad 4$ 
TABLE 8 cont.

Key to characters

I. Fore legs - length as \% of length of body spine (cervical to lumbar vertebrae) (from Hildebrand, I952a : fig. 6).

2. Hind legs - length as \% of length of body spine (as above).

3. Neck - length of cervical vertebrae as \% of combined length of thoracic and lumbar vertebrae (from Hildebrand, I952a : fig. I4).

4. Scapula - shape of teres major muscle scar on posterior angle : $0=$ on posterior border only, with plane at right angles to lateral face; $I=$ intermediate ; $2=$ whole scar on lateral face.

5. Scapula - extent of scar of serratus magnus muscle on medial side : o-I.

6. Pelvis - width as $\%$ of length $(\mathrm{a}: \mathrm{b})$.

7. Femur - length as $\%$ of length of tibia (c:d).

8. Femur - minimum width of shaft as $\%$ of length $(\mathrm{f}: \mathrm{c})$.

9. Third metatarsal - length as \% of length of femur $(e: c)$.

Io. Baculum - length as \% of condylobasal length.

II. Baculum - anterior end bifurcate : $\mathbf{0 - I}$.

I2. Baculum - well-defined protuberance on dorsal keel : O-I (see Hildebrand, I954, fig. I5).

13. Baculum - well-defined dorsal protuberance but no keel : o-I (as for I2).

I4. Caecum - shape : $0=$ straight ; $I=$ nearly straight ; $2=$ convoluted (from Flower, I879, I880; Garrod, I873, I878).

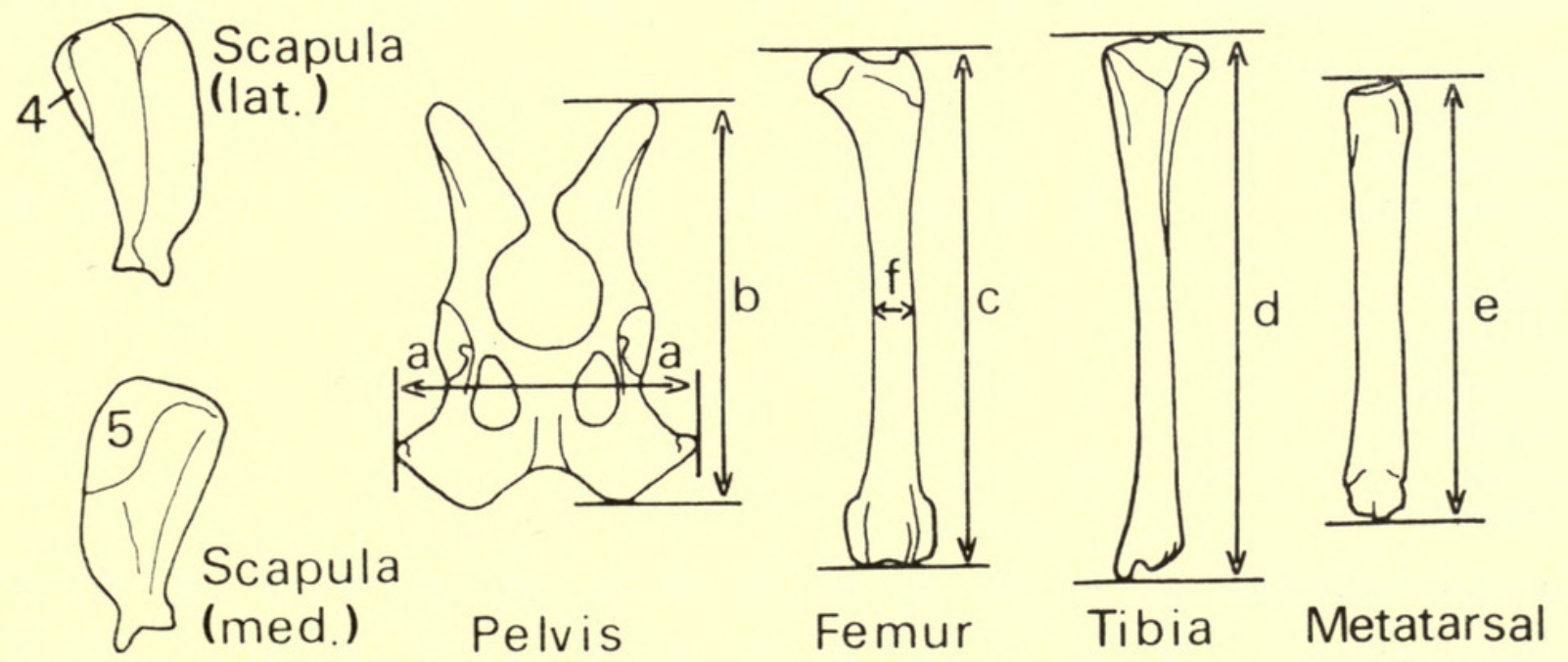




\section{TABLE 9}

Behaviour

Canis lupus

Dingo

Bloodhound

Canis latrans

C. aureus

C. mesomelas

C. adustus

C. simensis

Behaviour

Vulpes vulpes

V. corsac

V. ferrilata

$V$. bengalensis

V. cana

V. rueppelli

$V$. pallida

V. zerda

V. chama

V. velox

$V$. cinereoargenteus

$\begin{array}{cccccccccccccccc}\text { I } & 2 & 3 & 4 & 5 & 6 & 7 & 8 & 9 & \text { I0 } & \text { II } & \text { I2 } & \text { I3 } & \text { I } 4 & \text { I5 } & \text { I6 } \\ 2 & 2 & 3 & 0 & 0 & 0 & 2 & 0 & 0 & \text { I } & 0 & 0 & \text { I } & \text { I } & 2 & \text { I } \\ \text { I } & 0 & 2 & 0 & 0 & 0 & \text { I } & 0 & 0 & \text { I } & 0 & 0 & 0 & \text { I } & 2 & \text { I } \\ & & & & & & \text { I } & \text { I } & 0 & \text { I } & 0 & 0 & \text { I } & & 2 & \\ \text { I } & 2 & \text { I } & 0 & 0 & 0 & 2 & 0 & 0 & \text { I } & 0 & 0 & \text { I } & \text { I } & 2 & \text { I } \\ & 0 & & 0 & 0 & 0 & 2 & 0 & 0 & \text { I } & 0 & 0 & \text { I } & \text { I } & 2 & \text { I } \\ 0 & 0 & \text { I } & 0 & 0 & 0 & & 0 & 0 & \text { I } & 0 & 0 & \text { I } & & 2 & \text { I } \\ 0 & 0 & \text { I } & 0 & 0 & 0 & & 0 & 0 & \text { I } & 0 & 0 & \text { I } & & 2 & \text { I }\end{array}$

Alopex lagopus

Otocyon megalotis

o o o

000

o

o I 0

$\begin{array}{lllll}0 & 0 & 0 & \text { I } & \text { I }\end{array}$

$\begin{array}{lllllllllllllll}\text { Nyctereutes procyonoides } & 0 & 2 & 0 & \text { I } & \text { I } & 0 & 0 & I & 0 & & 3 & 0 & 0 & \text { I }\end{array}$

Dusicyon australis
D. culpaeus
D. culpaeolus
D. gymnocercus
D. inca
D. griseus
D. fulvipes
D. sechurae
$D$. vetulus
D. thous
D. microtis
$\begin{array}{llllll}0 & I & I & 0 & 0 & 0\end{array}$
$\begin{array}{llllll}0 & I & 2 & 0 & I & I\end{array}$

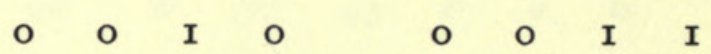

o 0 O I

$\begin{array}{llll}3 & 0 & 2 & 1 \\ 3 & 0 & 0 & 1\end{array}$

Chrysocyon brachyurus

Speothos venaticus

Cuon alpinus

Lycaon pictus

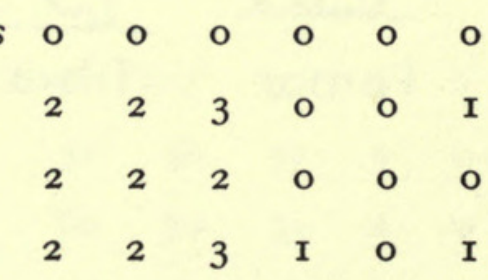

o

o

I

$\begin{array}{llll}\text { I } & \text { I } & \text { I } & \text { I } \\ \text { O } & 0 & \text { I } & 0 \\ \text { I } & & 0 & 0\end{array}$

$\begin{array}{lll}0 & 2 & \\ 0 & 2 & 1 \\ 0 & 2 & 1\end{array}$ 
TABLE 9 cont.

Key to characters (from Kleiman, I966, I967)

I. Diet - size of prey relative to body size : $0-2$.

2. Diet - proportion of meat: $o=$ varied - insects, vegetable, small vertebrates, carrion ; $\mathbf{I}=$ varied - insects and small vertebrates ; $2=$ mainly vertebrates.

3. Hunt socially: $\mathrm{O}=$ singly; $\mathrm{I}=$ singly or in pairs; $2=$ pairs or family groups ; $3=$ packs.

4. Ritual feeding: $\mathrm{O}-\mathrm{I}$.

5. Social grooming : $O=$ rare and only between pairs; $I=$ well developed.

6. Communal sleeping: $\mathrm{O}-\mathrm{I}$.

7. Howling : $\mathrm{O}=$ absent or only as long-distance contact call ; $\mathrm{I}=$ present but no physical contact ; $2=$ close-contact call, social howling in unison.

8. Frequency of oestrus phases for year: $\mathrm{O}=$ once; $\mathbf{I}=$ twice.

9. Female courtship posture : $\mathrm{o}=$ normal standing position as in domestic dog ; $\mathbf{I}=$ crouching position (lordosis) as in the cat.

Io. Copulatory tie present: $\mathrm{O}-\mathrm{I}$.

II. Urination in a spray : $\mathrm{O}-\mathrm{I}$.

12. Defecation at specific sites: $\mathbf{O}-\mathbf{I}$.

13. Tail posture in dominant animals : $\mathrm{O}=$ no distinct posture ; $\mathrm{I}=$ straight and horizontal ; $2=$ raised in a J-shape ; $3=$ inverted U-shape.

I4. Extent of teeth-baring in dominant threat posture: $\mathbf{O}-\mathbf{I}$.

15. Frequency of tail-wagging in submissive posture : $0-2$.

16. Regularly occupies an underground den : O-I. 
APPENDIX II: LICE (PHTHIRAPTERA) OF THE CANIDAE

The identification of ectoparasites, particularly lice which are often rigidly host-specific, can sometimes expose interesting relationships between different groups of animals. The following species of lice are listed by Hopkins (I949) as known to parasitise members of the Canidae:

Mallophaga, biting lice

Trichodectes (Trichodectes) canis de Geer

Canis lupus $\dagger$

Domestic dog, including dingo $* \dagger$

Canis latrans $\dagger$

Canis aureus, one record from a captive host

Dusicyon culpaeus, one record

Dusicyon fulvipes, one record, apparently from a wild host

Dusicyon thous $\dagger$

\section{Felicola (Suricatoecus) vulpis Denny}

Vulpes vulpes *†

Vulpes cinereoargenteus $\dagger$

Felicola (Suricatoecus) guinlei Werneck

Otocyon megalotis *

Felicola (Suricatoecus) fahrenholzi Werneck

Dusicyon fulvipes * $\dagger$

Dusicyon sechurae, one record from a museum skin

\section{Heterodoxus spiniger Enderlein}

Domestic dog $* \dagger$

Canis latrans $\dagger$

Canis aureus $\dagger$

Canis adustus and Cuon alpinus (see Kéler, 197I)

Anoplura, sucking lice

\section{Linognathus setosus von Olfers}

Canis lupus, one record, apparently on a wild host

Domestic dog * $\dagger$

Canis latrans, one record, no details

Canis aureus, one record, apparently on a wild host

Canis mesomelas $\uparrow$

Vulpes vulpes, one record on a captive host

Alopex lagopus $\dagger$

\section{Linognathus taeniotrichus Werneck}

Dusicyon fulvipes, one record on a captive host

Dusicyon thous * $\dagger$

* Nominal host for the species of louse listed.

$\dagger$ Natural occurrence of the species of louse established on this canid. 
The genus Heterodoxus is particularly interesting for, with the single exception of Heterodoxus spiniger, its hosts are confined to Australian marsupials. H. spiniger has the domestic dog for its nominal host and has been recorded frequently from the coyote and jackals. Until recently this species of Heterodoxus was not known to occur on marsupials but there is now a record (Kéler, I97I) for its presence on the wallaby, Wallabia agilis. Before this confirmed report Hopkins (I949) suggested that the species had evolved after transference to the dingo from a marsupial, perhaps shortly after dogs were introduced by man to Australia. This could have been in the early Holocene. The louse would then have spread to domestic dogs and thence to other wild canids as human populations moved about the world. At the present day $H$. spiniger is widespread on canids in many parts of Africa, Australia, America and Asia, but not apparently in Europe, Antarctica nor the northern regions of North America. Now that it is known, however, that $H$. spiniger does occur on a marsupial host it is possible that the transference to the dingo occurred at a later period; on the other hand, its presence on the wallaby could be a secondary transference back to a marsupial host.

The relationship between $H$. spiniger and its canid and marsupial hosts is obviously complicated, but it is possible that further work could throw light on the movements of human populations and the origins of their domestic dogs during the prehistoric period.

Support for the inclusion of the American grey fox (Urocyon cinereoargenteus) within the genus Vulpes, as proposed in this classification, is given by the louse, Felicola vulpis, which has been identified from both the common fox and the grey fox.

It was hoped there might be evidence for louse infestation on the skins of the extinct Falkland Island wolf, Dusicyon australis, and that this would lead to information on the relationships of this enigmatic canid. An examination (by $\mathrm{Mr} \mathrm{C}$. Moreby, British Museum (Natural History) ) of the two skins that are in the Museum collections failed to produce any signs of lice; as incidentally did the mummified skin of an Ancient Egyptian dog, also in the collections.

\section{REFERENCES}

Allen, G. M. I939. A checklist of African mammals. Bull. Mus. comp. Zool. Harv. 83 : I -763 .

Anon. 1950. Bull. zool. Nomencl. $4: 549$.

BlANFord, W. T. I888. The fauna of British India including Ceylon and Burmah. Mammalia. London.

Bobrinskir, N. A. 1965. Order Carnivora. In Bobrinskii, N. A., Kuznetsov, B. A. and Kuzyakin, A. P. [Key to the Mammals of the USSR]. Moscow (in Russian).

Bowdich, T. E. I821. An analysis of the natural classifications of Mammalia. Paris : 40.

BRINK, F. H. VAN DEN. I973. Distribution and speciation of some carnivores-2. Mammal Review, 3 : 85-95.

BUELeR, L. E. 1974. Wild dogs of the world. London.

Burmeister, C. H. C. I854. Systematische Uebersicht der Thiere Brasiliens. Berlin.

CABrera, A. I931. On some South American canine genera. J. Mammal. 12:54-67. 
Cabrera, A. 1958. Catalogo de los mamiferos de America del sur, I. Revta Mus. argent. Cienc. nat. Bernardino Rivadavia (Cienc. Zool.), 4 : 1-307.

- \& Yepes, J. I940. Mamiferos Sud-Americanos (vida, costumbres y descripción). Buenos Aires : $1-370$.

Chiarelli, A. B. I975. The chromosomes of the Canidae. In Fox (I975) : 40-53.

Clutton-Brock, J. I969. Carnivore remains from the excavations of the Jericho Tell. In Ucko, P. J. \& Dimbleby, G. W. (eds), The domestication and exploitation of plants and animals. London : 337-345.

— CORBET, G. B. I975. Vulpes Frisch, I775: proposed conservation under the plenary powers. Bull. zool. Nomencl. 32 : IIO-II2.

Corbett, L. \& Newsome, A. 1975. Dingo society and its maintenance: a preliminary analysis. In Fox (1975) : 369-379.

Creel, G. C., Thornton, W. A. \& Trimble, R. E. I971. Hybridization in the fox genus Vulpes in west Texas. S. West Nat. $15: 473-484$.

I974. Comparative study of a Vulpes fulva-Vulpes macrotis hybrid fox karyotype. S. West. Nat. $18: 465-468$.

Crisler, L. I959. Arctic wild. London.

DARWIN, C. I860. Journal of researches into the natural history and geology of the countries visited during the voyage of HMS Beagle round the world. London : 280 .

- \& Waterhouse, G. R. I840. The zoology of the voyage of HMS Beagle. Mammalia. London.

Ellerman, J. R. \& Morrison-Scott, T. C. S. I966. Checklist of palaearctic and Indian mammals 1758 to 1946 , and ed. London. London.

Fleming, J. 1822. The philosophy of zoology, or a general view of the structure, functions, and classification of animals. Edinburgh \& London, vol. $2: \mathbf{1 8 4}$.

Flower, W. H. I879. On the caecum of the red wolf (Canis jubatus, Desm.). Proc. zool. Soc. Lond. : 766-767.

- 1880. On the bush dog (Icticyon venaticus, Lund). Proc. zool. Soc. Lond. : 70-76.

1884. Catalogue of the specimens illustrating the osteology and dentition of the vertebrated animals contained in the museum of the Royal College of Surgeons of England. Part II Mammalia. London.

Fox, M. W. I970. A comparative study of the development of facial expressions in canids ; wolf, coyote and foxes. Behaviour (Leiden), 36:49-73.

I97I. Behaviour of wolves, dogs and related canids. London.
I975. The wild canids; their systematics, behavioral ecology and evolution. New York \& London.

Frisch, J. L. I775. Das Natur-System der vierfüssigen Thiere. Golgau : I5.

Garrod, A. H. I873. Note on the caecum of Canis cancrivorus. Proc. zool. Soc. Lond.: $748-75$ o.

I878. Notes on the visceral anatomy of Lycaon pictus and of Nyctereutes procyonoides. Proc. zool. Soc. Lond. : 373-377.

Gilmore, R. M. 1946. Mammals in archaeological collections from southwest Pennsylvania. J. Mammal. $27: 227-234$.

Gipson, P. S., Sealander, J. A. \& Dunn, J. E. 1974. The taxonomic status of wild Canis in Arkansas. Syst. Zool. 23 : I-II.

Golani, I. \& Keller, A. I975. A longitudinal field study of the behavior of a pair of golden jackals. In Fox (1975): 303-335.

Goodwin, H. A. \& Holloway, C. V. I972. Red databook I : Mammalia. Morges, Switzerland.

Gower, J. C. I966. Some distance properties of latent root and vector methods used in multivariate analysis. Biometrika, 53:325-338.

- 1971. A general coefficient of similarity and some of its properties. Biometrics, 27 : $857-87$ I. 
Gray, A. P. I972. Mammalian hybrids: a checklist with bibliography. Slough (Commonwealth Agricultural Bureaux).

Gray, J. E. I821. On the natural arrangement of vertebrose animals. London Med. Reposit. 15 : 296-3Io.

1825. Outline of an attempt at the disposition of the Mammalia into tribes and families.... Ann. Phil. N.s. 10 : 337-344.

I868. Notes on the skulls of the species of dogs, wolves and foxes (Canidae) in the collection of the British Museum. Proc. zool. Soc. Lond. : 492-525.

Groves, C. P. I97I. Request for a declaration modifying Article I so as to exclude names proposed for domestic animals from zoological nomenclature. Bull. zool. Nom. 27 : 269-272.

Guilday, J. E. I962. Supernumerary molars of Otocyon. J. Mammal. 43 : 455-462.

Hall, E. R. \& Kelson, K. R. 1959. The mammals of North America, vol. 2. New York.

Hamilton Smith, C. I839. Dogs I. The naturalists' library, ed. W. Jardine, vol. I8.

HARRISON, D. L. I968. The mammals of Arabia, vol. 2. London.

Heller, E. I9I4. New subspecies of mammals from equatorial Africa. Smithson. misc. Collns $63(7), \mathbf{I}-3$.

Hershkovitz, P. I957. A synopsis of the wild dogs of Colombia. Noved. colomb. 3 : I57-I6I.

— I96r. On the South American small-eared zorro Atelocynus microtis Sclater (Canidae). Fieldiana zool. 39 (44): 505-523.

- I972. The recent mammals of the Neotropical Region : a zoogeographic and ecological review. In Keast et al. (I972) : 3II-43I.

Hildebrand, M. I952a. An analysis of body proportions in the Canidae. Am. J. Anat. $90: 217-256$.

- 1952b. The integument in Canidae. J. Mammal. $33: 419-428$.

1954. Comparative morphology of the body skeleton in Recent Canidae. Univ. Calif. Publs Zool. 52 : 399-470.

Hopkins, G. H. E. I949. The host-associations of the lice of mammals. Proc. zool. Soc. Lond. $119: 387-604$.

Huxley, T. H. I880. On the cranial and dental characters of the Canidae. Proc. zool. Soc. Lond. : 238-288.

Imaizumi, Y. 1967. A new genus and species of cat from Iriomote, Ryukyu Islands. $J$. mammal. Soc. Japan, $3:$ 75-106.

KeAST, A., ERK, F.C. \& GLASS, B. I972. Evolution, mammalsandsoutherncontinents. New York.

KÉler, S. von. I97I. A revision of the Australasian Boopiidae (Insecta: Phthiraptera), with notes on the Trimenoponidae. Aust. J. Zool. suppl. 6: I-I26.

Kleiman, D. I966. Scent marking in the Canidae. In Jewell, P. A. \& Loizos, C. (eds), Play, exploration and territory in mammals. Symp. zool. Soc. Lond. 18 : 167-I77.

- I967. Some aspects of social behaviour in the Canidae. Am. Zool. $7: 365-372$.

KRAGLIEVICH, L. I93o. Craneometría y clasificación de los cánidos sudamericanos especialmente los angentinos actuales y fósiles. Physis. 10:35-73.

Krumbiegel, von I. I953. Der “Andenwolf”, Dasycyon hagenbecki (Krumbiegel, 1949). Säugetierk. Mitt. 1 : 97-104.

Küнme, W. I965a. Communal food distribution and division of labour in African hunting dogs. Nature, Lond. 205 : 443-444.

1965b. Freilandstudien zur Soziologie des Hyänenhundes (Lycaon pictus lupinus Thomas, I902). Z. Tierpsychol. $22: 495-54$ I.

LANGguth, A. I970. Una nueva clasificación de los canidos sudamericanos. Act. IV Congr. Latin. Zool. 1: I29-I43.

- 1975. Ecology and evolution in the South American canids. In Fox (1975) : 192-206.

LAWICK-Goodall, H. \& J. van. I970. Innocent killers. London.

LAWrence, B. \& Bossert, W. H. I967. Multiple character analysis of Canis lupus latrans and familiaris, with a discussion of the relationships of Canis niger. Am. Zool. 7: 223-232.

- 1975. Relationships of North American Canis shown by a multiple character analysis of selected populations. In Fox (1975) : 73-86. 
Lidicker, W. Z. I973. A phenetic analysis of some New Guinea rodents. Syst. Zool. 22 : $36-45$.

LitTLE, C. C. 1957. The inheritance of coat color in dogs. London.

LöNNBERG, E. I9I6. A remarkable occurrence of the first hind toe in the common fox (Vulpes vulpes). Ark. Zool. 10 (2I) : I-5.

Macpherson, A. H. 1969. The dynamics of Canadian arctic fox populations. Can. Wildl. Serv. Rep. Ser. no. $8: 1-52$.

MAJOR, F. I900. Remarks on remains of Cyon sardous from a cave in Sardinia. Proc. zool. Soc. Lond. : 833-835.

Marrett Tims, H. W. r896. On the tooth genesis in the Canidae. J. Linn. Soc. (Zool.) $25: 445-48$ o.

Matthew, W. D. I930. The phylogeny of dogs. J. Mammal. 11 : I17-r38.

MEcH, L. D. 1970. The wolf: the ecology and behaviour of an endangered species. New York.

Mengel, R. M. I97I. A study of dog-coyote hybrids and implications concerning hybridization in Canis. J. Mammal. 52:316-336.

Miller, G. S. I9I2. Catalogue of the mammals of Western Europe in the collection of the British Museum. London.

\& KELLOGG, R. I955. List of North American recent mammals. Washington.

Mivart, St G. I890. A monograph of the Canidae. London.

Newton, A. 1868. The secretary on additions to the menagerie. Proc. zool. Soc. Lond.: 529.

OGnev, S. I. 1962. Mammals of eastern Europe and northern Asia, vol. 2, Carnivora (Fissipedia). Israel Program for Scientific Translations. Jerusalem.

OsGood, W. H. I934. The genera and subgenera of South American canids. J. Mammal. $15: 45-50$.

- 1943. The mammals of Chile. Publs Field Mus. nat. Hist. (Zool.). 542 : I-222.

PARAdiso, J. L. I97I. A report on the taxonomic status and distribution of the red wolf. Wildlife (U.S. Fish \& Wildlife Service) no. I45: $1-36$.

\& Nowak, R. M. I972. Canis rufus. Mammalian Species no. $22: 1-4$.

Petter, G. I964. Origine du genre Otocyon (Canidae africain de la sous-famille des Otocyoninae). Mammalia 28 : 330-344.

Pocock, R. I. I913. The affinities of the antarctic wolf (Canis antarcticus). Proc. zool. Soc. Lond. : 382-393.

1936. The foxes of British India. J. Bombay nat. Hist. Soc. 39: 36-57.

— 1938. The jackals of S.W. Asia and S.E. Europe. Proc. zool. Soc. Lond. (B) 108: 37-39.

- 194I. The fauna of British India including Ceylon and Burma, vol. 2. London.

Pulliainen, E. 1967. A contribution to the study of the social behaviour of the wolf. $\mathrm{Am}$. Zool. 7 : 313-3 I 7.

RADINSKy, L 1973. Evolution of the canid brain. Brain, Behaviour and Evolution. 7 : I69-202.

Ride, W. D. L. I970. Native mammals of Australia. Oxford.

Romer, A. S. I955. Vertebrate palaeontology. Chicago.

Schenkel, R. 1967. Submission: its features and functions in the wolf and dog. $\mathrm{Am}$. Zool. $7:$ 319-33I.

Scotr, J. P. I967. The evolution of social behaviour in dogs and wolves. Am. zool. 7 : 373-38r.

Simpson, G. G. I945. The principles of classification and a classification of mammals. Bull. Am. Mus. nat. Hist. 85 : i-xvi, $\mathrm{I}-350$.

Sneath, P. H. A. \& Sokal, R. R. I973. Numerical taxonomy. San Francisco.

Thomas, O. I9I4. On various South American mammals. Ann. Mag. nat. Hist. ser. 8, $13: 345-363$.

I9I8. Some notes on the small sand-foxes of North Africa. Ann. Mag. nat. Hist. ser. 9, 1 : $243-245$.

TodD, N. B. I970. Karyotypic fissioning and canid phylogeny. J. theor. Biol. $26: 445-480$. 
Trouessart, E. L. I885. Catalogue des mammifères vivants et fossiles. Carnivora. Bull. Soc. Etud. Scient. Angers, 14 : I-Io8.

Troughton, E. I957. Furred animals of Australia. Sydney.

VAN Der Merwe, N. J. I953. The jackal. Fauna Flora Pretoria $4: 4-77$.

VAN Wormer, J. I964. The world of the coyote. Philadelphia \& New York.

Winge, H. I924. Pattedyr-Slaegter, vol. 2: Rodentia, Carnivora, Primates. Copenhagen.

Woolpy, J. H. \& Ginsburg, B. E. 1967. Wolf socialization : a study of temperament in a wild social species. Am. Zool. $7: 357-363$.

Juliet Clutton-Brock, Ph.D.

G. B. CORBET, Ph.D.

Department of Zoology

M. Hills, Ph.D.

Department of Central Services

British Museum (Natural History)

Cromwell RoAd

LONDON SW7 7 BD 


\section{$2 \mathrm{BHL}$ Biodiversity Heritage Library}

Clutton-Brock, Juliet, Corbet, G. B., and Hills, Michael. 1976. "A review of the family Canidae, with a classification by numerical methods." Bulletin of the British Museum (Natural History) Zoology 29, 117-199. https://doi.org/10.5962/bhl.part.6922.

View This Item Online: https://www.biodiversitylibrary.org/item/19532

DOI: https://doi.org/10.5962/bhl.part.6922

Permalink: https://www.biodiversitylibrary.org/partpdf/6922

\section{Holding Institution}

Natural History Museum Library, London

\section{Sponsored by}

Natural History Museum Library, London

\section{Copyright \& Reuse}

Copyright Status: In copyright. Digitized with the permission of the rights holder.

Rights Holder: The Trustees of the Natural History Museum, London

License: http://creativecommons.org/licenses/by-nc-sa/4.0/

Rights: http://biodiversitylibrary.org/permissions

This document was created from content at the Biodiversity Heritage Library, the world's largest open access digital library for biodiversity literature and archives. Visit BHL at https://www.biodiversitylibrary.org. 